\title{
UNIVERSIDADE DE SÃO PAULO ESCOLA DE ENFERMAGEM
}

\section{JOÃO HENRIQUE DE MORAIS RIBEIRO}

\section{DA REALIZAÇÃO PESSOAL AO DESCANSO MERECIDO:}

REPRESENTAÇÕES SOCIAIS DE IDOSOS JOVENS SOBRE TRABALHO E APOSENTADORIA 


\section{JOÃO HENRIQUE DE MORAIS RIBEIRO}

\section{DA REALIZAÇÃO PESSOAL AO DESCANSO MERECIDO: REPRESENTAÇÕES SOCIAIS DE IDOSOS JOVENS SOBRE TRABALHO E APOSENTADORIA}

Tese apresentada ao Programa de Pós-Graduação Interunidades EEUSP-EERP da Escola de Enfermagem da Universidade de São Paulo para obtenção do título de Doutor em Ciências.

Área de Concentração: Enfermagem

Linha de pesquisa: Fundamentos Teóricos e Filosóficos do Cuidar

Orientadora: Profa. Dra. Suely Itsuko Ciosak

São Paulo

2019 
AUTORIZO A REPRODUÇÃO E DIVULGAÇÃO TOTAL OU PARCIAL DESTE TRABALHO, POR QUALQUER MEIO CONVENCIONAL OU ELETRÔNICO, PARA FINS DE ESTUDO E PESQUISA, DESDE QUE CITADA A FONTE.

Assinatura:

Data:

Catalogação na Publicação (CIP)

Biblioteca "Wanda de Aguiar Horta"

Escola de Enfermagem da Universidade de São Paulo

Ribeiro, João Henrique de Morais

Da realização pessoal ao descanso merecido: representações sociais de idosos jovens sobre trabalho e aposentadoria / João Henrique de Morais Ribeiro. São Paulo, 2019.

$119 \mathrm{p}$.

Tese (Doutorado) - Escola de Enfermagem da Universidade de São Paulo.

Orientadora: Prof. ${ }^{a}$ Dr. ${ }^{\text {a }}$ Suely Itsuko Ciosak

Área de concentração: Enfermagem

1. Idosos. 2. Mercado de trabalho. 3. Aposentadoria. 4. Envelhecimento. 5. Enfermagem. I. Título.

Ficha catalográfica elaborada por Fabiana Gulin Longhi Palacio (CRB-8: 7257) 
Nome: João Henrique de Morais Ribeiro

Título: Da realização pessoal ao descanso merecido: representações sociais de idosos jovens sobre trabalho e aposentadoria.

Tese apresentada ao Programa de Pós-Graduação Interunidades EEUSP-EERP da Escola de Enfermagem da Universidade de São Paulo para obtenção do título de Doutor em Ciências.

Aprovada em:

\section{BANCA EXAMINADORA}

Orientadora: Profa. Dra. Suely Itsuko Ciosak

Instituição: Escola de Enfermagem da Universidade de São Paulo Assinatura:

Prof. Dr. Instituição:

Julgamento: Assinatura:

Prof. Dr. Instituição: Julgamento: Assinatura:

Prof. Dr. Instituição:

Julgamento: Assinatura: 


\section{DEDICATÓRIA}

Dedico, com todo minha gratidão, este trabalho à essas pessoas especais:

A Maria Goreti de Oliveira, uma mulher maravilhosa com quem tive a oportunidade de compartilhar uma etapa de minha vida e que desde o princípio me incentivou e me ajudou a chegar até aqui.

A Minha mãe, Dulciana, pelo exemplo de mulher trabalhadora e comprometida com os ideiais de sua profissão.

Ao Meu avô, João Morais, que aos 85 anos continua firme no serviço rural, dia a dia, cuidando do cafezal e da roça.

A minha orientadora, Suely Itsuko Ciosak, uma idosa jovem que encara o trabalho com uma vitalidade apreciável e que me ensinou a ser forte nos meus propósitos. 


\section{AGRADECIMENTOS}

Chegar ao final do Doutorado é uma mistura de dever cumprido e liberdade. Os anos passaram "voando"; até parece que foi ontem que o sonho estava começando.

Gostaria de agradecer a Deus, por ter me dado forças para sair da zona de conforto e encarar o novo nessa grande metrópole, me permitindo viver a maior de todas as transformações da minha vida. Transformações essas que ultrapassaram o desenvolvimento acadêmico e profissional, estendendo-se para minha vida pessoal, uma mudança radical de estilo de vida.

Certamente, não sou o mesmo João que chegou em São Paulo em 2015. Sorri, chorei, pensei em desistir diversas vezes mas a todo momento conseguia me reerguer com o carinho da minha família, amigos e das muitas pessoas que conheci durante essa caminhada.

Aos meus pais, Manoel e Dulciana, meus irmãos Ana Carolina e Ivan Luis todo o meu amor por vocês, que sempre apoiaram minhas decisões mesmo não entendo os motivos. Agradeço as palavras de incentivo, os puxões de orelha e o carinho demonstrado em nossos encontros na casa do pai e da mãe.

A minha tia Ivelise e minha prima Leila, por terem aberto a porta de sua casa e me acolhido no começo do Doutorado, sempre com zelo e cuidado para que eu me sentisse bem e confortável, mesmo mudando toda a rotina delas.

A Maria Goreti, uma mulher incrível que guardarei para sempre em meu coração. Go sem você esse sonho não teria se materializado. Agradeço pelas diversas vezes em que minhas necessidades foram prioridades em sua vida e por todo apoio que você, com toda cumplicidade, me ofereceu durante todos esses anos.

Ser aluno da EEUSP foi uma realização pessoal pois jamais imaginei que um dia conseguiria estar tão próximo de profissionais que, até então, só conhecia pelos livros e artigos que li durante minha graduação e especializações. E foi no Departamento de Enfermagem em Saúde Coletiva (ENS) que, digamos, montei meu acampamento. Foram incríveis esses anos de convivência! 
As todas as professoras do ENS minha admiração e respeito pelas contribuições e trocas de experiência em prol do meu aprimoramento profissional. Agradeço também a Valéria e a Socorro, que com todo zelo, cuidam do departamento e de todos nós.

A minha orientadora, Dra Suely Itsuko Ciosak, pela simplicidade e carinho que me ofereceu desde o primeiro contato. Agradeço pela seriedade, dedicação, oportunidades de aprendizado, zelo e amor compartilhado durante todo o percurso. Sem dúvidas, me sinto um privilegiado por tido você como minha orientadora.

A Dra. Cássia Baldini Soares pelas indicações valiosas de leitura sobre trabalho e a Dra. Célia Maria Sivalli Campos por todo carinho, olhar atento e acolhedor que muitas vezes suavizaram a rotina acadêmica.

Gostaria de fazer um agradecimento especial à Dra. Maria Clara Padoveze e a Dra. Lúcia Yasuko Izumi Nichiata, coordenadoras da disciplina de Enfermagem em Doenças Transmissíveis com enfoque em Saúde Coletiva, por terem acreditado no meu potencial e investido em minhas ideias durante os anos em que trabalhamos juntos na disciplina. Poder acompanhar o desenvolvimento de uma estratégia de ensino foi um grande diferencial para minha formação docente e isso foi possível graças a vocês. Muito Obrigado.

As especialistas do ENS, Érica Gomes Pereira, Vânia Ferreira Gomes Dias, Karen Namie Sakata So e Eloá Otrenti que carinhosamente passei a chamar de "Especiamigas" pelo acolhimento, palavras de apoio, incentivo e boas risadas, deixando os dias duros mais suaves e fáceis de serem encarados.

Entre as especiamigas, um destaque para Eloá Otrenti, uma amiga que a EEUSP me deu. De uma aproximação discreta surgiu uma grande parceria e que, com o passar dos anos, foi se consolidando cada vez mais e se transformou numa relação de amizade, confiança e admiração.

Às minhas amigas, aquelas que frequentavam o olímpo do ENS, Lucimara Eloá, Rafaela, Paula, Bárbara, Eline, Luiza, obrigado pela convivência, pelas trocas, companhia para almoço, baladinhas e pelo ombro amigo quando precisei de amparo para descarregar minhas incertezas e compartilhar minhas vitórias.

A Dra. Renata Ferreira Takahashi e a Dra. Marilia Louvison pela disponibilidade e valiosas contribuições durante o Exame de Qualificação. 
A Edima, Jéssica e Sandra, equipe coordenadora do Projeto Samuel Rangel, por terem aberto o espaço e me acolhido para a realização da coleta de dados.

Aos colegas do grupo de pesquisa Senescência e Senilidade: desafios no cuidar em saúde pelos momentos de alegria e compartilhamento de saber.

A bibliotecária chefe Juliana Akie Takahashi pelas preciosas dicas e contribuições durante a revisão de literatura e escrita da tese. Ao Paulo César Machado Pereira pelo carinho e boas conversas todas as vezes em que ia até a biblioteca.

Ao Conselho Nacional de Desenvolvimento Científico e Tecnológico - CNPq pela concessão da bolsa de estudos durante o Doutorado.

Ao Programa Interunidades de Doutoramento em Enfermagem da EEUSP e ao Serviço de Pós-graduação da Escola de Enfermagem, em particular a Mara, por toda a atenção dispensada durante o Doutorado.

E a todos os idosos que participaram deste estudo. Obrigado por terem me recebido e cedido esse tempo para que eu pudesse ouvir suas histórias de vida. Agradeço por terem confiado a mim essas vivências.

Sinto-me feliz e emociado por ter recebido tanto apoio e carinho durante esses anos.

A todos vocês, o meu sincero agradecimento!!! 
“... Um homem se humilha,

Se castram seus sonhos

Seu sonho é sua vida

E vida é trabalho

E sem o seu trabalho

O homem não tem honra

E sem a sua honra

Se morre, se mata..."

Um homem também chora (Guerreio Menino)

Gonzaguinha 
Ribeiro JHM. Da realização pessoal ao descanso merecido: representações sociais de idosos jovens sobre trabalho e aposentadoria [tese]. São Paulo: Escola de Enfermagem, Universidade de São Paulo; 2019.

\section{RESUMO}

Introdução: o modo como o trabalho e a aposentadoria são percebidos pelo indivíduo está conectado à sua história e projeto de vida, mantendo uma relação com as mudanças historicamente ocorridas na sociedade e no mundo do trabalho, além da importância atribuída ao convívio, rotina e papéis desempenhados dentro e fora do ambiente laboral. Objetivo: identificar e analisar os significados de trabalho e aposentadoria para o idoso jovem. Método: estudo prospectivo, observacional e exploratório de abordagem quanti-qualitativa, que empregou as Representações Sociais como referencial teórico e seguiu as orientações do Consolidated Criteria for Reporting Qualitative Research (COREQ). Foram selecionados para este estudo idosos jovens, ou seja, com idade entre 60 e 70 anos, aposentados ou não, residentes em dois munícipios selecionados, de ambos os sexos, com qualquer nível de instrução, capazes de responder a entrevista e que aceitassem participar da pesquisa mediante assinatura do Termo de Consentimento Livre e Esclarecido. O formulário utilizado para a coleta de dados foi elaborado em duas partes: a primeira contendo questões sobre as características socioeconômicas, condições de saúde e trabalho e, a segunda, questões norteadoras que tinham o objetivo de promover reflexões dos participantes e colher seus depoimentos sobre os significados do trabalho e aposentadoria. Para conhecer a capacidade funcional e cognitiva dos participantes e a presença de quadro depressivo foram empregados três instrumentos consagrados e validados: Mini Exame do Estado Mental, Escala de Lawton e Escala de Depressão Geriátrica (EDG-15). Os dados socioeconômicos, de trabalho e de saúde foram armazenados e tabulados em planilha do Microsoft Excel $\circledast$, analisados por meio de estatística descritiva. Os discursos dos idosos jovens foram transcritos na íntegra e analisados por meio do referencial de Análise de Conteúdo de Bardin. Resultados: o perfil socioeconômico e as condições de trabalho e saúde mostraram uma população de idosos com funcionalidade, cognição e humor preservadas, majoritariamente feminina, com uma boa auto percepção de saúde e de capacidade para o trabalho. Além disso, eram idosos com hábitos de vida saudáveis, que participavam de diferentes atividades sociais e de lazer. Pelos discursos o trabalho foi associado à necessidade e ao senso de utilidade individual e coletivo. A tomada de decisão entre permanecer ativo no trabalho foi percebida como dificuldade, uma vez que expressam o desejo de continuar trabalhando em rotinas mais flexíveis, independente da comunidade onde residiam. A aposentadoria foi vista como descanso merecido e prêmio por terem atingido os requisitos necessários para sua concessão. O período de transição para a aposentadoria dos idosos favoreceu a adoção de estratégias para adaptação à nova rotina de vida. Conclusão: os resultados encontrados mostram que mesmo com boa saúde e capacidade para o trabalho auto percebidas, a decisão entre aposentar e continuar trabalhando está relacionada à forma como cada idoso compreende trabalho e aposentadoria.

Palavras-Chave: Idoso; Idoso jovem, Mercado de trabalho; Aposentadoria; Envelhecimento; Enfermagem. 
Ribeiro JHM. Personal fulfillment to the well-deserved rest: social representations of young seniors about work and retirement [thesis]. São Paulo: Escola de Enfermagem, Universidade de São Paulo; 2019.

\begin{abstract}
Introduction: the way in which work and retirement are perceived by the individual is connected to his / her life history and project, maintaining a relationship with the changes that have occurred historically in society and in the world of work, besides the importance attributed to social interaction, routine and roles within and outside the working environment. Objective: to identify and analyze the meanings of work and retirement for the young seniors. Method: A prospective, observational and exploratory quantitative-qualitative study that used the Social Representations as a theoretical reference and followed the guidelines of the Consolidated Criteria for Reporting Qualitative Research (COREQ). For this study, we selected young seniors, aged 60 to 70 years old, who were either retired or not, living in two selected municipalities, of both sexes, with any level of education, able to respond to the interview and who accepted to participate in the study by signing the Term of Free and Informed Consent. The data collection form was drawn up in two parts: the first containing questions on socioeconomic characteristics, health and work conditions, and the second, guiding questions that were intended to promote reflection on the participants and to collect their testimonies about the meanings of work and retirement. In order to know the functional and cognitive capacity of the participants and the presence of depressive symptoms, three validated instruments were used: Mini Mental State Examination, Lawton Scale and Geriatric Depression Scale (GDS-15).

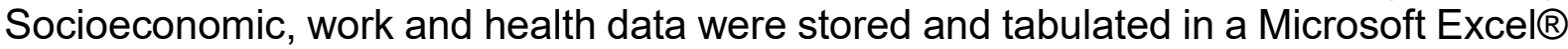
worksheet, analyzed using descriptive statistics. The discourses of the elderly youth were transcribed in full and analyzed through the Bardin Content Analysis framework. Results: socioeconomic profile and working and health conditions showed a population of elderly people with preserved functionality, cognition and humor, mostly female, with a good self perception of health and work capacity. In addition, they were elderly people with healthy living habits, who participated in different social and leisure activities. Through the discourses the work was associated with the need and the sense of individual and collective utility. Decision making between staying active at work was perceived as difficult, as they expressed the desire to continue working in more flexible routines, regardless of the community where they lived. Retirement was seen as a well-deserved rest and award for having achieved the necessary requirements for its concession. The transition period for the retirement of the elderly favored the adoption of strategies to adapt to the new routine of life. Conclusion: the results show that even with good health and self-perceived ability to work, the decision between retiring and continuing to work is related to the way each elderly person understands work and retirement.
\end{abstract}

Keywords: Aged; Young Senior; Labor Market; Retirement; Aging; Nursing. 


\section{LISTA DE ILUSTRAÇÕES}

\section{FIGURAS}

Figura 01 Distribuição relativa da população de 60 anos e mais ocupada entre 2002 e 2014 de acordo com a síntese de indicadores das PNADs. São Paulo, 2017.

Figura 02 Desvelando as representações sociais sobre trabalho e aposentadoria para idosos jovens. São Paulo, 2019 68

\section{QUADRO}

Quadro 01 Processo analítico das entrevistas e as categorias segundo o Referencial Teórico. São Paulo, 2019 


\section{LISTA DE TABELAS}

Tabela 01 Condições favoráveis à permanência ou reinserção dos idosos no mercado de trabalho. São Paulo, 2019

Tabela 02 Condições que favorecem a aposentadoria precoce, por tempo e por invalidez de idosos inseridos no mercado de trabalho. São Paulo, 2019 32

Tabela 03 Evolução histórica do Sistema Previdenciário Brasileiro. São Paulo, 2019 35

Tabela 04 População idosa por faixa etária e sexo, segundo município de origem. São Paulo, 2019 54

Tabela 05 Características socioeconômicas de idosos jovens segundo localidade. São Paulo, 2019

Tabela 06 Condição de trabalho e ocupação dos idosos jovens segundo localidade. São Paulo, 2019.

Tabela 07 Condição de saúde de idosos jovens segundo localidade. São Paulo, 2019. 


\section{LISTA DE ABREVIATURAS E SIGLAS}

\begin{tabular}{ll} 
ALC & América Latina e Caribe \\
CAP & Caixa de Aposentadorias e Pensões \\
CEPAL & Para a Comissão Econômica para a América Latina e Caribe \\
CF & Constituição Federal \\
CLT & Consolidação das Leis do Trabalho \\
COFINS & Contribuição para o Financiamento da Seguridade Social \\
COREQ & Consolidated Criteria for Reporting Qualitative Research \\
CSLL & Contribuição Social sobre o Lucro Líquido das Empresas \\
EC & Emenda Constitucional \\
EDG-15 & Escala de Depressão Geriátrica \\
EEUSP & Escola de Enfermagem de São Paulo \\
ENS & Enfermagem em Saúde Coletiva \\
FSP & Faculdade de Saúde Pública \\
FP & Fator previdenciário \\
Funrural & Fundo de Assistência ao Trabalhador Rural \\
IAPS & Institutos de Aposentadoria e Pensão \\
IBGE & Instituto Brasileiro de geografia \\
IDH & Índice de Desenvolvimento Humano \\
INPS & Instituto Nacional de Previdência Social \\
IP & Instituto de Psicologia \\
LOPS & Lei Orgânica da Previdência Social \\
MEEM & Mini-Exame do Estado Mental \\
MP & Medida Provisória \\
\hline
\end{tabular}

OCDE Organização para a Cooperação e o Desenvolvimento Econômico 


$\begin{array}{ll}\text { OMS } & \text { Organização Mundial de Saúde } \\ \text { PEA } & \text { População economicamente ativa } \\ \text { PEC } & \text { Proposta de Emenda à Constituição } \\ \text { PIA } & \text { População em idade ativa } \\ \text { PIB } & \text { Produto Interno Bruto } \\ \text { PIS } & \text { Programa de Integração Social } \\ \text { PME } & \text { Pesquisa Mensal de Empregos } \\ \text { PNAD } & \text { Pesquisa Nacional por Amostra de Domicílios } \\ \text { PNSPI } & \text { Política Nacional de Saúde da Pessoa Idosa } \\ \text { PREVIC } & \text { Previdência Complementar } \\ \text { PS } & \text { Previdência Social } \\ \text { RGPS } & \text { Regime Geral da Previdência Social } \\ \text { RPPS } & \text { Regime Próprio de Previdência Social } \\ \text { RS } & \text { Representações Sociais } \\ \text { SPB } & \text { Sistema Previdenciário Brasileiro } \\ \text { TCLE } & \text { Termo de Consentimento Livre Esclarecido } \\ \text { TRS } & \text { Teoria das Representações Sociais } \\ \text { UNIFAL-MG } & \text { Universidade Federal de Alfenas - Minas Gerais } \\ \text { WHO } & \text { World Health Organization }\end{array}$




\section{SUMÁRIO}

1 INTRODUÇÃO

1.1 VELHICE, TERCEIRA IDADE E ENVELHECIMENTO SAUDÁVEL: INTERFACE COM TRABALHO E APOSENTADORIA AO LONGO DA HISTÓRIA

1.2 TRABALHO E APOSENTADORIA: ASPECTOS RELEVANTES NO CONTEXTO DO ENVELHECIMENTO

2 JUSTIFICATIVA

3 MARCO TEÓRICO 43

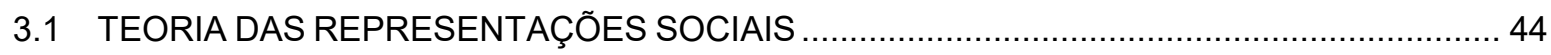

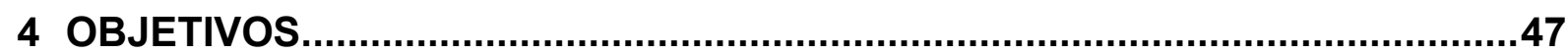

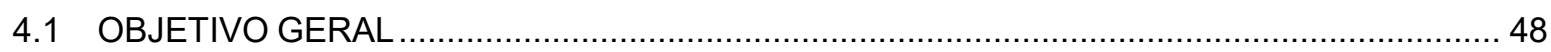

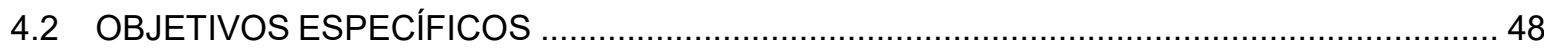

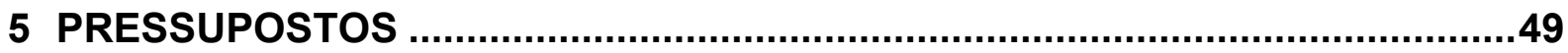

6 PERCURSO METODOLÓGICO …......................................................................

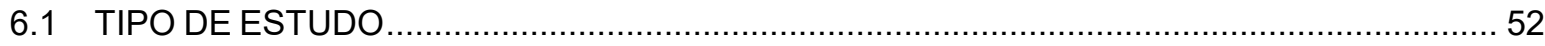

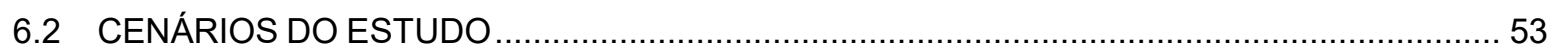

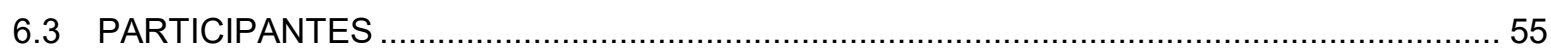

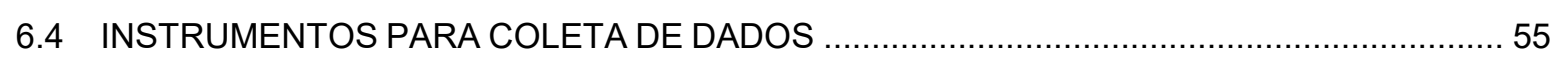

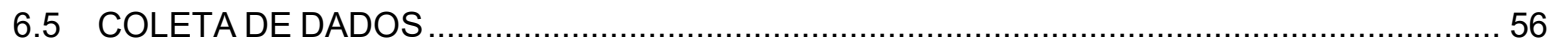

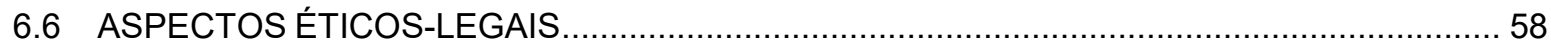

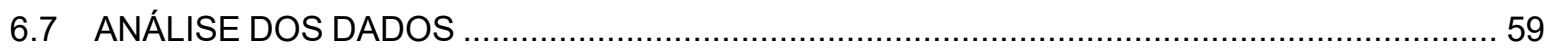

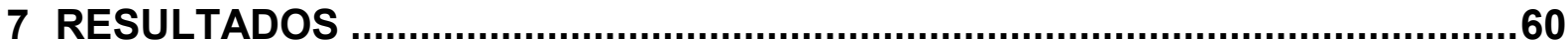

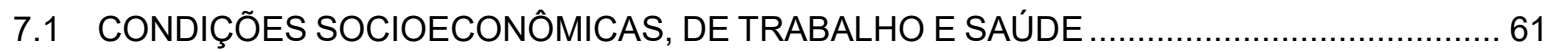

7.2 REPRESENTAÇÕES SOCIAIS SOBRE TRABALHO E APOSENTADORIA ......................... 66

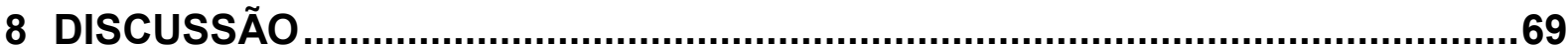

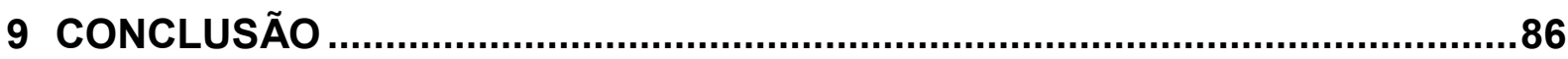

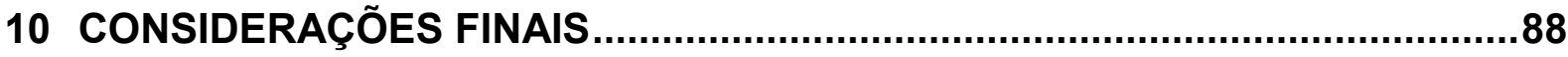

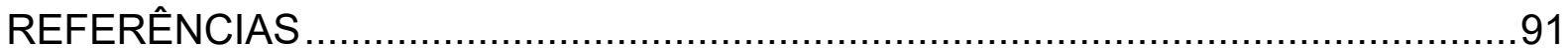

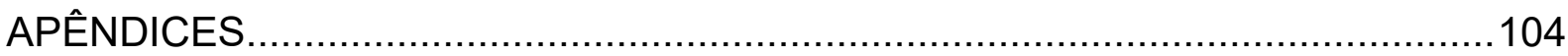

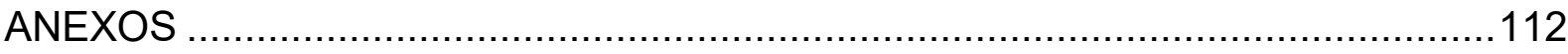




\section{APRESENTAÇÃO}

Meu interesse em estudar mais profundamente a temática do idoso no mercado de trabalho ocorreu durante minha atuação profissional em diferentes setores de saúde da minha cidade natal, Campos Gerais MG, onde percebia que um grande número de idosos já afastados de suas atividades laborais, procuravam as unidades com frequência e, de certa forma, aumentavam a demanda por diferentes tipos de serviço, especialmente as consultas médicas e a prescrição de medicamentos.

Nesse mesmo tempo, tive a oportunidade de cursar a especialização em Gerontologia pelo Departamento de Ciências Humanas da Universidade Federal de Alfenas (UNIFAL-MG), na qual foi possível ampliar meus conhecimentos acerca do envelhecimento e sua diversidade, o que, na época, reforçou ainda mais meu interesse na temática.

Foi com esse pensamento que ingressei no Mestrado, desenvolvido na Escola de Enfermagem da UNIFAL-MG e finalizado em 2014, cujo título foi "Capacidade para o trabalho da pessoa idosa: caracterizando uma outra identidade social".

Foi uma grande satisfação visualizar que os idosos estudados no Mestrado tinham uma ótima capacidade para o trabalho e percebi que outras questões sobre essa temática ganharam espaço em meu pensamento, o que me fez procurar o Doutorado.

Entrei em contato primeiramente com professoras da Escola de Enfermagem de Ribeirão Preto, pois nesse período atuava como professor do curso Técnico em Enfermagem no Instituto Federal de Educação, Ciência e Tecnologia do Sul de Minas Gerais - Campus Muzambinho e, pela proximidade, conseguiria conciliar o trabalho e a progressão nos estudos. No entanto, não obtive sucesso com esses contatos.

Foi então que resolvi "vasculhar" o site da Escola de Enfermagem de São Paulo (EEUSP) e vendo a aba dos grupos de pesquisa encontrei o grupo Senescência e Senilidade: desafios para o cuidar em saúde. Naquele momento, não hesitei em entrar em contato com a líder, a Profa. Dra. Suely Itsuko Ciosak, hoje minha orientadora. 
No primeiro e-mail, contei para Suely sobre minha pesquisa no mestrado e o interesse em dar continuidade na temática e a mesma, sempre gentil, me convidou para participar de uma reunião do grupo. Lembro-me como se fosse hoje a primeira vez que a vi, entrando na sala, toda agitada e preocupada em acolher todos os participantes. Ao final da reunião tive a oportunidade de conversar com ela sobre o projeto e ver sobre as possibilidades de ingressar no Doutorado.

E assim aconteceu. Participava das reuniões do grupo, trocávamos e-mail e fui escrevendo o projeto. Vim para a EEUSP investigar o significado de trabalho e aposentadoria para idosos entre 60 e 70 anos influenciado pelos resultados da minha dissertação. Mesmo sabendo que aqueles idosos tinham uma ótima capacidade para trabalhar, me inquietava as razões pelas quais alguns permaneciam e outros deixavam o mercado de trabalho. E ficava me questionando: será mesmo que eles continuam a trabalhar só porque o dinheiro da aposentadoria era pouco?

Me preparei para o Processo Seletivo até que, no dia 25 de abril de 2015 fiz minha matrícula como aluno regular no Programa Interunidades de Doutoramento de Enfermagem da Escola de Enfermagem e Escola de Enfermagem de Ribeirão Preto da Universidade de São Paulo.

Durante o Doutorado, participei ativamente das oportunidades que a EEUSP me ofereceu: cursei disciplinas na Escola de Enfermagem, na Faculdade de Saúde Pública e no Instituto de Psicologia, obtendo conceito A na maioria delas, fui aluno do Programa de Aperfeiçiamento de Ensino por 3 anos consecutivos na disciplina de Doenças Transmissíveis, atuei como representante discente da Comissão do Programa Interunidades e da Comissão de Pesquisa, avaliador de trabalhos no SIICUSP, moderador na apresentação dos trabalhos de conclusão de curso da graduação, além de participar dos colóquios, aulas abertas, eventos e treinamentos da biblioteca. 


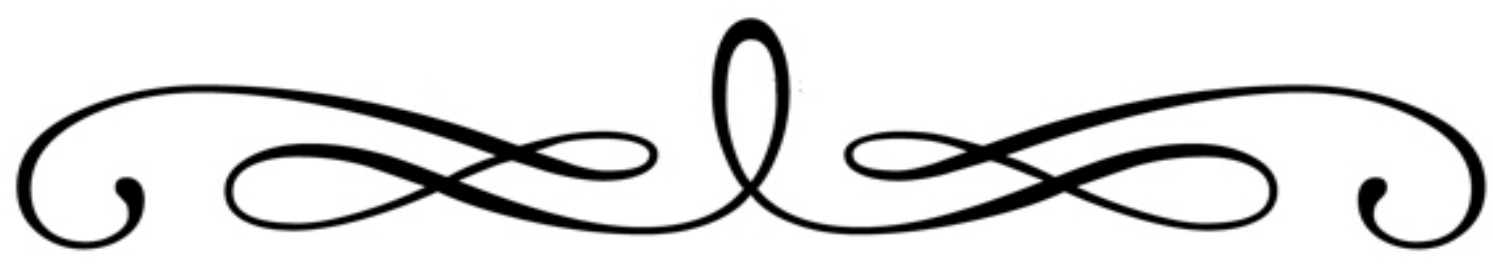

1 INTRODUÇÃO

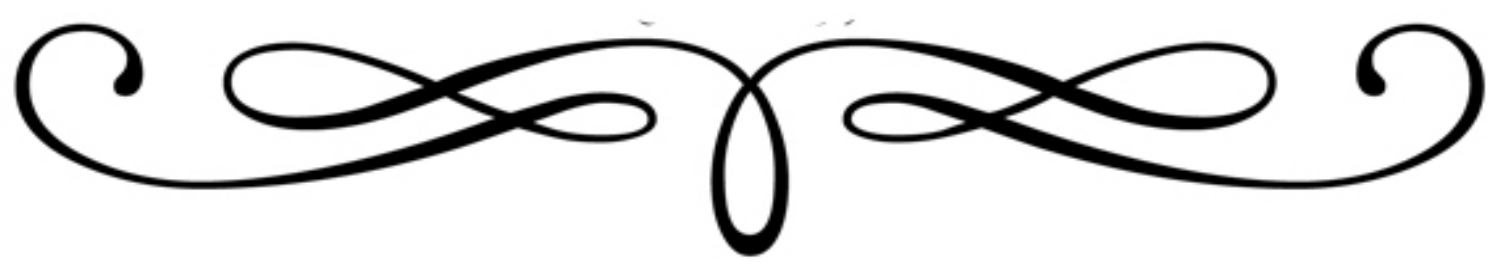




\section{INTRODUÇÃO}

Este estudo enfatiza os significados de trabalho e aposentadoria para idosos entre 60 e 70 anos, denominados idosos jovens1, considerando o aumento de sua participação no mercado laboral nos últimos anos e o impacto gerado em suas vidas e saúde após o desligamento com o trabalho.

O envelhecimento é uma etapa do ciclo vital; um processo natural, multidimensional e progressivo que provoca alterações graduais e inevitáveis nos aspectos biológico, emocional, cultural e social (Ciosak et al., 2011). Na atualidade, se configura como um dos maiores desafios para a história da humanidade e pode ser comparado aos problemas decorrentes da industrialização e urbanização vivenciados pela sociedade ao longo de seu desenvolvimento (Brasil, 2017).

Em 1950, a população idosa mundial era cerca de 204 milhões de pessoas e, passadas seis décadas, essa população chegou a 841 milhões de indivíduos (United Nations, 2013). Em 2015, o número de idosos atingiu aproximadamente $12 \%$ da população e esse número continuou expandindo (United Nations, 2015), ao passo que, em meados de 2017, atingimos 7,6 bilhões de idosos em todo o mundo (United Nations, 2017).

Esse grupo populacional continua a crescer cerca de 1,1\% anualmente, gerando mais de 83 milhões de idoso a cada ano. De acordo com as projeções, o número de idosos no mundo poderá aumentar nos próximos 13 anos, atingindo 8,6 bilhões já em 2030 e ultrapassar os nove bilhões em 2050 (United Nations, 2017).

O processo de envelhecimento é decorrente do declínio progressivo na taxa de mortalidade e, posteriormente, na queda das taxas de natalidade e fecundidade, associado às melhorias no padrão da vida dos indivíduos, a inovação médica e aos programas de saúde pública (Fernandes, Zordan, 2012; Alves, Vasconcelos, Carvalho, 2010; Ramos, Veras, Kalache, 1992). A diminuição dessas taxas ocasionou mudanças na estrutura etária da população tanto nos países desenvolvidos quanto naqueles em desenvolvimento (Brito, Litovic, 2004).

\footnotetext{
${ }^{1}$ De acordo com o Instituto de Pesquisa Econômica Aplicada são denominados idosos jovens àqueles com idade entre 60 e 70 anos e que podem viver de maneira independente, com ausência ou pequenas restrições quanto à realização das atividades diárias (IPEA, 2007).
} 
Nos países desenvolvidos, a população envelheceu em um cenário socioeconômico favorável que possibilitou a expansão dos sistemas de seguridade social e a melhoria na renda da população. As políticas públicas objetivavam a manutenção do papel dos idosos na sociedade e a promoção e manutenção de sua autonomia (Camarano, Pasinato, 2004).

Já nos países em desenvolvimento, como o Brasil, o envelhecimento acontece de forma profunda e acelerada, modificando o perfil demográfico do país, que passou de uma sociedade jovem, rural, composta por famílias numerosas e com alto risco de morte na infância para outra, envelhecida, urbana, com diferentes arranjos familiares (famílias com ou sem filhos, uniões homoafetivas entre outras) e com baixo risco de morte na infância (Vasconcelos, Gomes, 2012). Diante destas mudanças o país poderá assumir, de acordo com Veras (2009) a sexta posição mundial em números de pessoas idosas em 2020.

O Brasil segue envelhecendo sem antes solucionar uma lista ampla problemas de ordem social, como educação, saúde, pobreza e exclusão de alguns grupos da sociedade, que somados à outras necessidades dessa população poderão se agravar, caso não sejam resolvidos. Além disso, a temática ganhou destaque na agenda política influenciada pela visão negativa e deficitária do envelhecimento, característica de sociedades ocidentais que focalizam a produção e a juventude (Camarano, 2013, Ferreira et al., 2010; Camarano, Pasinato, 2004; Uchôa, 2003).

De acordo com o Instituto Brasileiro de Geografia e Estatística (IBGE) o segmento de idosos é o que mais aumenta na população brasileira, com taxa de crescimento que ultrapassa $4 \%$ ao ano, considerando o período entre 2012 a 2020 . A população com 60 anos e mais era de aproximadamente 14 milhões em 2000 e passados 10 anos, atingiu a marca de 19,6 milhões de pessoas (IBGE, 2015).

Para os próximos 10 anos, espera-se um aumento médio anual de mais de um bilhão de idosos, superando os 40 milhões em 2030 e os 70 milhões em 2060 (IBGE, 2015).

Além do crescimento nos números absoluto e proporcional de idosos, a expectativa de vida ao nascer aumenta gradualmente. Em 2014, o brasileiro vivia em média 75,2 anos e poderá atingir uma expectativa de vida ao nascer masculina entre 85 e 90 anos, e feminina na faixa de 90 a 95 anos em 2050 (Souza, Melo, 2017).

Esse novo perfil demográfico envelhecido tem despertado o interesse de gestores, profissionais da saúde e pesquisadores por representar campo fértil de 
atuação e produção de conhecimento científico voltado às necessidades da população idosa, fornecendo estratégias para enfrentamento dos inúmeros desafios advindos deste panorama. Dessa forma, torna-se necessária a mobilização constante da sociedade para tornar o envelhecimento uma das prioridades na agenda do país (Haan, Prowse, 2014; Rodrigues et al., 2007; Wong, Carvalho, 2006).

Em meio à diversidade de desafios determinados por uma sociedade que envelhece, o aumento na participação de pessoas idosas no mercado de trabalho tem se tornado evidente nos últimos anos (Wajnman, Oliveira, Oliveira, 2004) e nesse contexto, países desenvolvidos e em desenvolvimento vêm adotando medidas para assegurar o equilíbrio atuarial dos sistemas de Previdência Social, entre os quais destacam-se o incentivo à permanência de idosos no mercado de trabalho bem como o adiamento da aposentadoria (Félix, 2016; Furtado, 2005).

A síntese de indicadores da Pesquisa Nacional por Amostra de Domicílios (PNAD) mostra que ao longo dos últimos anos, a distribuição de pessoas ocupadas 2 com 60 anos e mais vem aumentando, conforme ilustra a figura 01.

Figura 01 - Distribuição relativa da população de 60 anos e mais ocupada entre 2002 e 2014 de acordo com a síntese de indicadores das PNADs. São Paulo, 2017

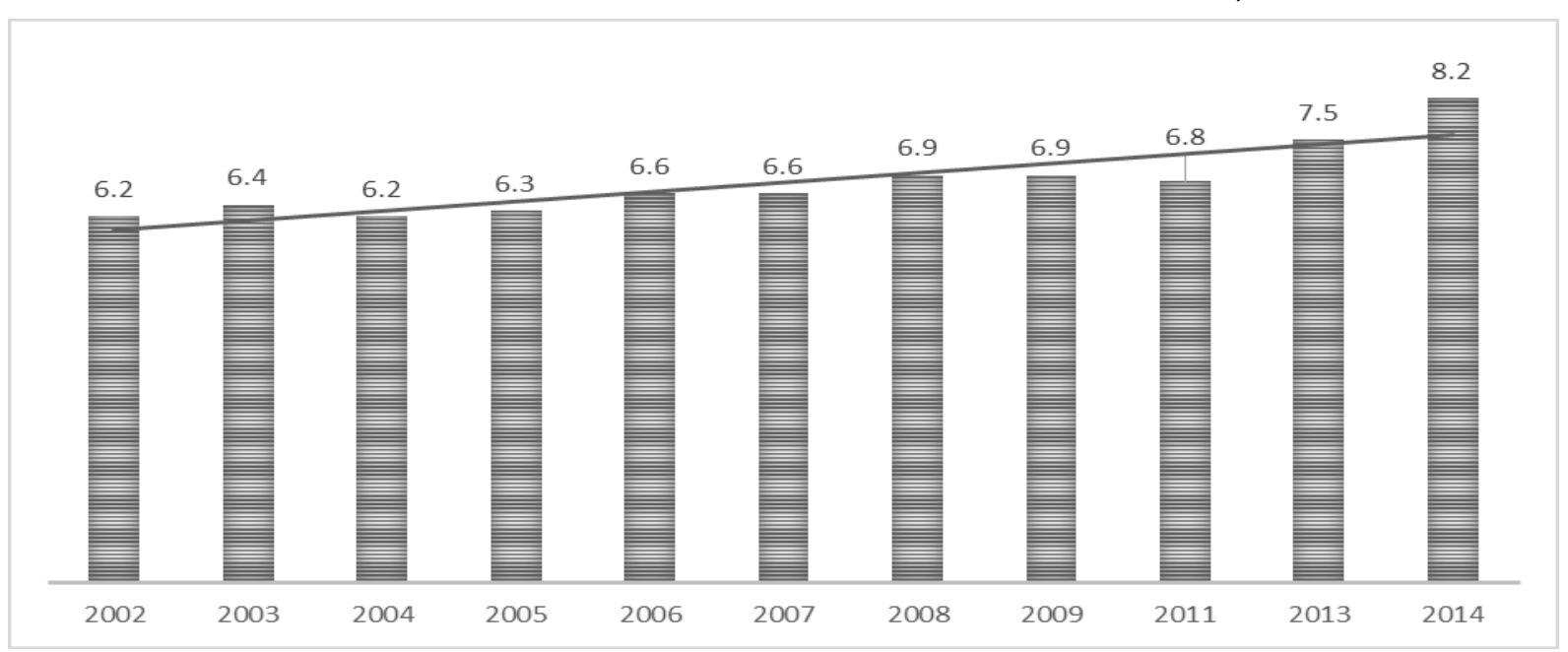

Fonte: Pesquisa Nacional por Amostra de Domicílios. IBGE.

\footnotetext{
2 Pessoas ocupadas eram aquelas que tinham trabalho durante todo ou parte do período de referência do levantamento. Foram incluídas ainda as pessoas que não exerceram o trabalho remunerado no período, por motivo de férias, licença, greve etc (IBGE, 2016).
} 
Essa participação cada vez mais significativa de idosos no trabalho está relacionado à necessidade de manter-se produtivo e valorizado no seu contexto social, como meio de lutar contra a solidão, o isolamento e pelas dificuldades econômicas encontradas para manter o padrão de consumo individual e muitas vezes, familiar (Sá et al., 2011).

A entrada no mundo do trabalho pelos idosos está relacionada a renda domiciliar, a escolaridade e a condição de saúde, sendo que idosos com autonomia e mobilidade física preservadas tem maior probabilidade de permanecerem na vida ativa até as idades mais avançadas (Giatti, Barreto, 2003).

Os vários anos dedicados ao trabalho despertam em algumas pessoas, a necessidade de desvincular-se de suas atividades laborais por meio da aposentadoria (França et al., 2013). O ato de aposentar é um direito estabelecido por lei que garante amparo ao trabalhador, pagamentos mensais vitalícios que o auxiliam a prover sua autonomia e integração social (Mendes et al., 2005).

Para alguns, essa fase é encarada de forma positiva, representando a oportunidade de reorganização da vida, na retomada de antigos projetos, na dedicação a atividades intelectuais, desportivas e sociais, as quais foram postergadas pelo tempo dedicado ao trabalho formal (Caldas, 2009).

Já para outros, a aposentadoria é acompanhada de significados prejudiciais, podendo ocasionar insegurança, medo, depressão, irritabilidade e insatisfação com vida, dificultando o processo de adaptação a essa fase, ocasionando reduções na qualidade de vida (França et al., 2013; Alvarenga et al., 2009).

O modo como o trabalho e a aposentadoria são percebidos pelo indivíduo apresenta múltiplas interfaces, conectadas à sua história e projeto de vida, mantendo relação com as mudanças historicamente ocorridas na sociedade em geral e no mundo do trabalho, além da importância atribuída ao convívio, rotina e papéis desempenhados dentro e fora do ambiente de trabalho no decorrer dos anos vividos (Araújo et al., 2013; Bulla, Kaefer, 2003).

Nesse contexto, emergiram as indagações: Por que alguns idosos optam pela aposentadoria enquanto outros continuam trabalhando? O que os faz continuar no trabalho? O que significa trabalho e aposentaria para eles? Questões estas que buscamos desvelar com este estudo. 


\subsection{VELHICE, TERCEIRA IDADE E ENVELHECIMENTO SAUDÁVEL: INTERFACE COM TRABALHO E APOSENTADORIA AO LONGO DA HISTÓRIA}

Como vimos, o acelerado envelhecimento populacional tem se destacado na sociedade moderna e pode ser encarado como um grande desafio para as próximas gerações sobretudo em relação aos esforços para examinar, problematizar e elaborar estratégias inovadoras para compreender esse processo, bem como proporcionar por meio do Estado e sociedade, respostas políticas adequadas para solucionar as demandas desse grupo populacional (Gleason, 2017; Miranda, Mendes, Silva, 2016; Küchemann, 2012; Silva, 2008).

$\mathrm{Na}$ atualidade coexistem distintas maneiras para designar as idades mais avançadas do ciclo vital, entre elas velhice e terceira idade. Essas categorias etárias foram construídas socialmente sob a influência da industrialização e das alterações demográficas no início do século XIX e tem como finalidade, demarcar os períodos de cada fase da vida e atribuir identidades, hábitos e espaços relacionados para cada grupo etário (Rozendo, 2010; Debert, 2007, Hareven, 1995).

Para categorizar um indivíduo como velho é preciso levar em consideração seus aspectos cronológico, biológico, psicológico, social e cultural e não apenas a idade, haja visto que adotar a idade como único marcador desse processo reduz a experiência do envelhecer apenas à referência de que o tempo está passando, o que em si não determina o envelhecimento (Schneider, Irigaray, 2008).

Nessa perspectiva, pode-se assumir que não há uma idade singular que defina o início da velhice. Essa delimitação etária vem sendo empregada para a criação de políticas públicas, na demarcação de direitos e deveres, para auxiliar na comparação de dados populacionais, entre outras. A Organização Mundial de Saúde (OMS) determina que em países desenvolvidos é considerado idoso o indivíduo com idade igual ou superior a 65 anos e para àqueles em desenvolvimento, 60 anos e mais. Vale ressaltar que essa classificação leva em consideração o status socioeconômico de cada país (Felipe, Souza, 2014; WHO,2002).

O significado de velhice em nossa sociedade é permeado por crenças, mitos, preconceitos e estereótipos que menosprezam tanto o processo de envelhecimento em si quanto o sujeito que envelhece (Almeida, Lourenço, 2009). 
O ser velho representa um conjunto de atribuições e transformações negativas que estão ligadas ao conceito tradicional de velhice. No imaginário social o velho está diretamente associado à estagnação e perdas que levam à ruptura e ao isolamento; inflexibilidade decorrente de apego a valores ultrapassados e cristalizados que também levam ao isolamento social; imagem negativa do aposentado, significando um final de vida, falta de capacidade pessoal e a exclusão da rede produtiva; pessoa que necessita de cuidados, sem força, sem vontade, sem vida, doente, incapacitado e que por todos esses motivos fez opção pela passividade (Rodrigues, Soares, 2006. p. 8)

Logo, a velhice carrega consigo o estigma de perdas significativas como a decadência física, o surgimento de doenças crônico-degenerativas, a perda do poder econômico, a ausência de papéis sociais valorizados, a viuvez, entre outros o que destina aos idosos uma vida sem significado e o rótulo de ser um peso para suas famílias e Estado (Freitas, Queiroz, Souza, 2010; Debert, 2004).

Em meados do século XIX, a classe operária chama a atenção para a velhice enquanto um problema social, em decorrência da acelerada expansão do capitalismo e seu código de normas, na qual a velhice passa a ser vista pelo patronato do capital como invalidez, ou seja, incapacidade para produzir (Lenoir, 1996). Assim, todas as formas de invalidez que acometiam os trabalhadores eram confundidas com a velhice que passou a identificar a todos que, no final de suas vidas, não eram mais aptos para desempenhar seu trabalho (Silva, 2008).

Já na segunda metade do século XIX, influenciados pela ameaça da massa de trabalhadores que envelhecia, surgem as caixas de aposentadoria, uma espécie de recompensa para os trabalhadores mais velhos que recebiam, na visão dos empresários, mais do que produziam. Na verdade, era uma estratégia dos capitalistas para manter a disciplina, a rentabilidade e a produção dos trabalhadores (Lenoir, 1996).

Em decorrência da institucionalização das caixas de aposentadorias, surgem os agentes especializados para gerenciar a velhice, sua consolidação enquanto categoria etária bem como sua identidade, a evidente associação entre velhice e invalidez. Em um contexto que privilegiava a capacidade e a posição do ser humano no trabalho, ser aposentado era, nomeadamente, inválido, incapaz e desocupado, concepção está que mais se consolidou no imaginário social (Silva, 2008).

Essa identidade entre velhice e invalidez, por sua vez, contribuiu para que a velhice fosse estabelecida como categoria política, transformando os aposentados em 
sujeitos de direito, permitindo assim que os mesmos pudessem reivindicar e exigir seus benefícios sob o status do idoso (Silva, 2008; Katz, 1996).

Na sociedade contemporânea, a associação da invalidez com a velhice vem sendo desfeita graças a um movimento que busca reverter a carga negativa e depreciativa que ela traz consigo ao longo da história, denominado Terceira Idade. Esse termo surgiu na França, entre as décadas de 60 e 70 e era empregado para descrever a idade na qual a pessoa se aposentava (Schneider, Irigaray, 2008; Rodrigues, Soares, 2006).

Mais do que uma referência à idade cronológica, a Terceira Idade vem proporcionar novos olhares e formas para se viver após os 60 anos, enfatizando o prazer e a realização pessoal. É, de fato, a possibilidade de reconstrução dos conceitos e concepções pejorativas acerca do processo de envelhecer e também, o atendimento à demandas e interesses de um mercado de consumo emergente, com ostensiva visibilidade social atualmente (Birman, 2015, Almeida, Lourenço, 2009; Rodrigues, Soares, 2006, Debert, 1999).

Nesse contexto, o termo "velho" não especifica mais esses jovens senhores uma vez que vinha carregado do estigma da decadência e incapacidade. Emerge, então, a denominação "idoso", indicando maior respeito e um novo perfil no estilo de vida das pessoas, compondo a arte do bem viver o envelhecimento (Silva, 2008; Groisman, 1999; Peixoto, 1998).

De maneira geral, pertencem a Terceira Idade os idosos até 70 anos e incluem, principalmente, aqueles que mantém bom padrão de saúde e tempo disponível para a realização de diferentes atividades e experiências (Siqueira, Botelho, Coelho, 2002).

A Terceira Idade proporciona o protagonismo do idoso em relação ao seu processo de envelhecimento, promove a autoimagem positiva frente a vida, favorece a aceitação das limitações e perdas decorrentes do processo e auxilia na busca de adaptações a essas perdas. Além disso, provoca o autodesenvolvimento e a auto realização em diferentes espaços sociais (Rodrigues, Soares, 2006).

Fundamentadas por essa nova concepção, as políticas públicas têm enfatizado a contribuição do idoso no cotidiano social e trabalhista, promovendo o sentido positivo do envelhecimento, que pode ser expressado por diferentes termos: envelhecimento ativo, bem-sucedido e, atualmente, envelhecimento saudável conforme as recomendações da OMS (Tavares et al., 2017). 
Envelhecimento saudável é definido como o processo de desenvolvimento e manutenção da capacidade funcional que permite o bem-estar em idade avançada (OMS, 2015).

Reflete a combinação entre a capacidade intrínseca (capacidade física, mental e os ambientes em que vivem) e capacidade funcional, vista como a interação entre indivíduo e meio, que inclui atributos que permitem às pessoas executarem tarefas diárias, preservar as atividades mentais e se integrar na sociedade (Beard et al., 2016; OMS, 2015; Brito, Litovic, 2004).

Nesse contexto, os propósitos nos serviços de saúde deixam de ter foco apenas no prolongamento da vida e passam a investir, também, na manutenção e promoção dessas capacidades, de forma que o idoso permaneça autônomo e independente, atendendo assim a finalidade primordial da Política Nacional de Saúde da Pessoa Idosa (Brasil, 2006; Costa, Nakatani, Bachion, 2006).

Alguns estudos evidenciaram que independência, autonomia, saúde física, segurança financeira, interação e relação social são percebidos pelos idosos como componentes para o envelhecimento saudável (Tavares et al., 2017; Stephens, Breheny, Mansvelt, 2015; Sixsmith et al.,2014; Boratti, Soriano, 2013; Cupertino, Rosa, Ribeiro, 2007) e consequentemente, podem ser considerados como condições relevantes para a inserção e permanência dos idosos no mundo do trabalho (Sá et al., 2011; Giatti, Barreto, 2003).

Ao longo de nossas vidas, somos impulsionados ao trabalho contínuo e, por meio dele o homem, enquanto ser social, efetiva o ato de produzir e reproduzir. Estar fora do trabalho, nesse aspecto, é estar fora da vida, excluído da reprodução social (Muniz, Barros, 2014; Teixeira, 2009).

A ligação do trabalho e da aposentadoria ao longo da construção da terceira idade nos proporciona a superação na forma como concebemos o envelhecimento, reforçado ultimamente pela OMS quando conceituou envelhecimento saudável.

Com a expansão do capitalismo, a velhice foi atrelada ao signo da incapacidade, da invalidez e reproduzido no imaginário social. Porém, com um novo olhar para a Terceira Idade é possível vislumbrar uma nova forma de conceber o envelhecimento na sociedade moderna, no seu sentido positivo, o qual possibilita o protagonismo dos idosos, que podem optar entre permanecer ou não no trabalho, de acordo com suas necessidades, uma vez que os mesmos continuam produzindo. 


\subsection{TRABALHO E APOSENTADORIA: ASPECTOS RELEVANTES NO CONTEXTO DO ENVELHECIMENTO}

A participação de idosos no mercado de trabalho tem sido cada vez mais frequente, decorrente do envelhecimento populacional, do aumento da expectativa e qualidade de vida dos indivíduos na modernidade. Pode-se observar que as pessoas, nessa nova era, têm se preocupado em manter-se mais ativas nos grupos sociais, sobretudo nas atividades laborais (Freitas, Campos, Gil, 2017).

O trabalho humano é uma atividade determinada e transformadora, que apresenta uma multiplicidade de significados. Seu conteúdo oscila entre dor/fardo e prazer/alegria pelas atividades que transformam a matéria em objeto de cultura. Propicia também ao indivíduo, a criação de instrumentos necessários para sua sobrevivência e realização na sociedade em que vive (Albornoz, 1994; Carmo, 1992).

O trabalho é, ainda, matéria de discussão ao longo da história, marcado por lutas entre as classes, alienação, acumulação, sua precarização, desqualificação e cortes geracionais, incluindo teses de que seu fim estaria próximo (Antunes, 2008).

Para Lucaks (1978) a essência do trabalho é a ligação direta do homem com a luta pela existência e são frutos de sua auto atividade. Em termos ontológicos, o trabalho tem um caráter intermediário na medida em que é, basicamente, uma interrelação entre homem (sociedade) e natureza orgânica e inorgânica, assinalando a passagem no homem que trabalha do ser meramente biológico ao ser social.

De acordo com Marx (1996 p. 172) o trabalho é "uma condição de existência do homem, independente de todas as formas de sociedade, eterna necessidade natural de mediação do metabolismo entre homem e natureza e, portanto, da vida humana".

Em nossa cultura, o trabalho representa um dos pilares da autoestima, da afirmação da identidade, do senso de utilidade e, como ato consciente, apresenta uma necessária dimensão ética-moral, tornando-se elemento constitutivo do ser social e, deste modo, assume caráter central e estruturante na vida dos homens, tanto em função das relações econômicas quanto dos contatos sociais (Magalhães et al., 2004; lamamoto, 2000).

O aumento no número de idosos trabalhando tem despertado o interesse da sociedade mundial que busca progredir na formulação de políticas que incentivem o prolongamento da vida produtiva e o adiamento da aposentadoria, com evidência às 
questões da ampliação da idade legal para sua efetivação (Ribeiro, 2018; Nilsson, 2018; Tanaka et al., 2018; Sewdas, 2018).

Nos Estados Unidos, em 1990, 11,9\% da força de trabalho era composta por pessoas com 55 anos e mais, após 20 anos, houve aumento progressivo na participação desse grupo, atingindo a marca de 19,5\%. Projeções indicam que em 2020 a participação desse grupo no mercado de trabalho pode atingir 25,2\% (Toossi, 2012). A taxa de participação de americanos com 65 anos e mais em 2013 foi de 14\% para o sexo feminino e $22 \%$ para o masculino, podendo atingir $28 \%$ e $27 \%$, respectivamente, nos próximos sete anos (Hayutin, Beals, Borges, 2013).

Para idosos americanos, o prazer no trabalho está associado a mudanças para ocupações mais flexíveis e a realização de trabalho autônomo. A despeito disso, a pressão pela aposentadoria e a ênfase na promoção de trabalhadores mais jovens levaria a uma redução desse prazer. De maneira geral, percebiam o trabalho de maneira positiva em suas vidas (Choi et al., 2018).

Nos países europeus, como Finlândia, Reino Unido, Lituânia, Alemanha e Áustria, a condição de emprego de pessoas com 65 anos e mais vem aumentando desde 2005 e são esperados contínuos avanços na participação no mercado de trabalho por idosos. Em 2000, a taxa de emprego para pessoas entre 55 e 64 anos era de 37\%, aumentando 10\% em 10 anos (Sinclair, Watson, Beach, 2013). Recentes projeções da Comissão Europeia apontam que a participação dessas pessoas em atividades laborais pode atingir 67\% em 2060, estimando ainda que a idade média para saída do trabalho avance de 62 para 64 anos (European Comission, 2015).

$\mathrm{Na}$ Itália, por exemplo, o aumento no número de cidadãos idosos e a insustentabilidade do sistema de previdência social levou o governo a aumentar a idade de aposentadoria e reduzir as chances de efetivação da aposentadoria precoce. Dessa forma, passou a investir em programas de promoção da saúde para trabalhadores idosos, que focalizavam estratégias voltadas para melhorias no ambiente, nos relacionamentos e na organização de trabalho, bem como o incentivo à qualificação desses trabalhadores (Magnavita et al., 2017).

Já no Brasil, a participação de idosos no mercado de trabalho é alta quando comparada aos padrões internacionais e esse aumento, como já destacava Camarano (2001), poderia estar relacionado com a falta de impedimentos legais para que a pessoa aposentada continue trabalhando ou seja novamente captada para o mercado. 
Entre 2002 e 2006, a Pesquisa Mensal de Empregos - PME (IBGE, 2012) revelou que brasileiros acima dos 50 anos representavam cerca de $18,1 \%$ do total de pessoas ocupadas, sendo que destes, $24,1 \%$ trabalhavam com carteira assinada no setor privado e 32,7\% eram trabalhadores autônomos, o que para Wajnman, Oliveira, Oliveira (2004) pressionou o mercado de trabalho na perspectiva de geração de empregos. Para este mesmo grupo, em dezembro de 2015 a PME registrou $26,2 \%$ de trabalhadores no total de pessoas ocupadas (IBGE, 2015) e, em fevereiro de 2016 houve um discreto aumento, assumindo $26,6 \%$ (IBGE, 2016).

Em 2010, os idosos ocupados no Brasil mantinham jornada de trabalho de 40 a 44 horas semanais. No último trimestre de $2013,6,5 \%$ da população ocupada era formada por idosos e neste mesmo ano foi registrado uma elevação de 11,6\% nos postos de trabalho para indivíduos acima de 65 anos, aumento este relacionado ao avanço no grau de instrução desses trabalhadores (IBGE, 2013a, IBGE, 2013b).

A necessidade de complementar a renda pessoal ou familiar, a manutenção das relações sociais, bem como a motivação individual, tem incentivado os idosos a se reinserirem no mercado de trabalho ou permanecerem nele, possibilitando novos aprendizados e valorização de suas experiências profissionais, reduzindo o déficit causado pelo sistema previdenciário (Queiroz, Ramalho, Cavalcanti, 2005).

Nesse contexto, buscou-se na literatura nacional e internacional condições que poderiam contribuir para a permanência ou reinserção dos idosos no mercado de trabalho, conforme apresentados na Tabela 01.

Tabela 01 - Condições favoráveis à permanência ou reinserção dos idosos no mercado de trabalho. São Paulo, 2019

\begin{tabular}{|c|c|c|}
\hline Autor & $\begin{array}{l}\text { País/ Ano de } \\
\text { publicação }\end{array}$ & $\begin{array}{c}\text { Condições para permanência ou reinserção } \\
\text { no mercado de trabalho }\end{array}$ \\
\hline Torrely & Brasil - 2008 & $\begin{array}{l}\text { Vida ativa; Manutenção das atividades laborais; Gosto } \\
\text { e prazer pelo trabalho; Autonomia e liberdade; } \\
\text { Sensação de utilidade; Questões financeiras; Relações } \\
\text { interpessoais }\end{array}$ \\
\hline Virtanen & Finlândia -2014 & $\begin{array}{l}\text { Ausência de transtorno mental e sofrimento psíquico; } \\
\text { Controle do tempo de trabalho }\end{array}$ \\
\hline Supranowicz & Polônia - 2014 & Motivação financeira; Apoio social \\
\hline Stenholm et al. & Finlândia - 2014 & Manutenção e promoção do bom funcionamento físico \\
\hline Taylor et al. & Austrália - 2014 & $\begin{array}{l}\text { Trabalho autônomo; Maior escolaridade; Segurança } \\
\text { financeira; Flexibilidade nas horas de trabalho }\end{array}$ \\
\hline
\end{tabular}


(continuação)

\begin{tabular}{|c|c|c|}
\hline Autor & $\begin{array}{l}\text { País/ Ano de } \\
\text { publicação }\end{array}$ & $\begin{array}{c}\text { Condições para permanência ou reinserção } \\
\text { no mercado de trabalho }\end{array}$ \\
\hline Sewdas et al. & Holanda - 2017 & $\begin{array}{l}\text { Manutenção das rotinas diárias; Benefícios financeiros; } \\
\text { Boa saúde; Arranjos flexíveis de trabalho }\end{array}$ \\
\hline Di Gessa et al. & Londres - 2017 & $\begin{array}{l}\text { Boa autopercepção de saúde; Melhor status } \\
\text { socioeconômico }\end{array}$ \\
\hline Nicholson, Mayho. & Londres - 2017 & $\begin{array}{l}\text { Politicas flexíveis; Locais de trabalho seguro e } \\
\text { saudáveis; Acesso à saúde ocupacional; Programas de } \\
\text { promoção da saúde; Treinamento ou requalificação; } \\
\text { Ajustes no papel e no ambiente de trabalho }\end{array}$ \\
\hline Gonzales, Nowell, & EUA - 2017 & $\begin{array}{l}\text { Trabalho voluntário formal ou informal; Parceria com o } \\
\text { cônjuge }\end{array}$ \\
\hline Dong et al. & EUA - 2017 & Triagem no local de trabalho para sintomas de insônia \\
\hline Magnavita et al. & Roma - 2017 & $\begin{array}{l}\text { Melhorias no ambiente de trabalho; Qualificação dos } \\
\text { trabalhadores; Melhorias na organização do trabalho; } \\
\text { Ações de promoção da saúde no ambiente de trabalho }\end{array}$ \\
\hline Noone et al. & Austrália - 2018 & Centralidade no trabalho; Ajuste pessoa-trabalho \\
\hline Maatouk et al. & Alemanha - 2018 & $\begin{array}{l}\text { Intervenções preventivas na saúde mental com } \\
\text { enfermeiras acima de } 45 \text { anos, que podem ser } \\
\text { realizadas para outras áreas de trabalho. }\end{array}$ \\
\hline Wind et al. & Holanda - 2018 & $\begin{array}{l}\text { Para idosos sem doença crônica: Melhor saúde } \\
\text { física; Maior altura corporal; menor carga de trabalho } \\
\text { físico; Ausência de contrato permanente }\end{array}$ \\
\hline & & $\begin{array}{l}\text { Para idosos com doença crônica: Sentir-se cheio de } \\
\text { vida; estar ativo fisicamente (acima de } 2 \text { semanas) }\end{array}$ \\
\hline$\underline{\text { Tang et al. }}$ & EUA - 2018 & $\begin{array}{l}\text { Satisfação com a vida; trabalhar em setor público; } \\
\text { Pagamento somente em dinheiro }\end{array}$ \\
\hline Choi et al. & EUA - 2018 & Prazer no trabalho; Trabalho autônomo \\
\hline $\begin{array}{l}\text { Tomioka, } \\
\text { Kurumatani, Saeki. }\end{array}$ & Japão - 2018 & Serviços de saúde ocupacional eficientes \\
\hline Van der Zwaan et al & Holanda - 2018 & $\begin{array}{l}\text { Boa saúde física; Pró atividade; Trabalho interessante; } \\
\text { Valorização; Trabalho voluntário }\end{array}$ \\
\hline Ribeiro et al. & Brasil - 2018 & $\begin{array}{l}\text { Melhores condições sociais (renda, educação); Melhor } \\
\text { condição de saúde; Satisfação com a vida }\end{array}$ \\
\hline
\end{tabular}

(conclusão)

Como vemos o trabalho não está associado somente à geração de renda; é através desta atividade que as pessoas estabelecem suas rotinas, planos e metas diárias, expressam sua produtividade, constroem laços afetivos, além de garantir sua autonomia e independência, principalmente na sociedade moderna, fortemente influenciada pelo modelo capitalista de produção (Alvarenga et al., 2009; Rodrigues et al., 2005). 
Com as alterações na dinâmica demográfica evidencia-se um acelerado aumento da relação entre a quantidade de idosos e a população em idade ativa ${ }^{3}$ (PIA) o que, no cenário atual, tem possibilitado a reformulação de conceitos acerca da aposentadoria dado a menor proporção de jovens e a uma longevidade saudável (Costanzi, Ansiliero, 2017; Beach, 2014).

Apesar de já poderem se aposentar, um número cada vez maior de aposentados continua trabalhando e nesse sentido, a aposentadoria vem assumindo importância crescente para os indivíduos da terceira idade (Wind et al., 2018; Tanaka et al., 2018; Sewdas et al., 2018; Settels, McMullin, 2017).

A aposentadoria pode ser encarada como a fronteira que demarca o limite entre dois períodos do curso de vida, ou seja, a ocupação da atividade laboral e o afastamento da mesma (Ekerdt, 2010). Em meio às mudanças nas demandas e organização do trabalho, esse termo vem sofrendo mudanças ao longo da história e sua definição é considerada por alguns autores confusa e ambígua (Ekerdt, 2010; Denton, Spencer, 2009).

Portanto, é relevante definir o conceito adotado neste estudo:

(1) "estado de inatividade daquele que se aposentou com determinando vencimento ao fim de certo tempo de serviço", (2) direito que tem o empregado, depois de certo número de anos de atividade ou por invalidez e (3) remuneração recebida mensalmente pelo beneficiário que se aposentou (Michaellis, 2019, sp.)

Dessa forma, a aposentadoria pode ser vista como um fenômeno que engloba condições que variam desde o rompimento parcial com a carreira até a saída total das atividades laborais, seja ela voluntária ou não. Essas condições são afetadas de acordo com a expectativa da pessoa em relação à aposentadoria, atitudes do grupo social em relação a ela, obrigações familiares, condições socioeconômicas, trabalhistas, de saúde, disponibilidade e oportunidade para aprendizados, trabalho e lazer (Hershenson, 2016). A Tabela 02 sintetiza algumas condições apontadas na literatura que contribuem para a aposentadoria.

\footnotetext{
${ }^{3}$ População em idade ativa compreende a população economicamente ativa e a população não economicamente ativa (IBGE, 2019).
} 
Tabela 02 - Condições que favorecem a aposentadoria precoce, por tempo e por invalidez de idosos inseridos no mercado de trabalho. São Paulo, 2019

\begin{tabular}{|c|c|c|}
\hline Autor & $\begin{array}{l}\text { País e ano de } \\
\text { publicação }\end{array}$ & $\begin{array}{c}\text { Condições que contribuem para } \\
\text { aposentadoria (precoce ou não e por } \\
\text { invalidez) }\end{array}$ \\
\hline Koskenvuo et al. & Finlândia - 2011 & $\begin{array}{l}\text { Fumar prediz o risco de aposentadoria por } \\
\text { invalidez devido à Doença Pulmonar Obstrutiva } \\
\text { Crônica }\end{array}$ \\
\hline Van Rooij, Lusardi, Alessie & USA - 2011 & $\begin{array}{l}\text { Educação financeira para planejamento da } \\
\text { aposentadoria }\end{array}$ \\
\hline Salonsalmi et al. & Finlândia - 2012 & $\begin{array}{l}\text { Consumo de álcool e transtornos mentais } \\
\text { derivados do uso estão associados à } \\
\text { aposentadoria precoce. }\end{array}$ \\
\hline $\begin{array}{l}\text { Olesen, Butterworth, } \\
\text { Rodgers }\end{array}$ & Austrália - 2012 & $\begin{array}{l}\text { Baixa saúde física e mental; Maior participação } \\
\text { em atividades sociais; ter um cônjuge }\end{array}$ \\
\hline Robroek et al. & Holanda - 2013 & $\begin{array}{l}\text { Saúde precária; Comportamentos insalubres } \\
\text { (Sedentarismo); Trabalho com características } \\
\text { desfavoráveis }\end{array}$ \\
\hline Wind et al. & Holanda - 2014 & $\begin{array}{l}\text { Idade mais avançada; Saúde física precária; } \\
\text { Atitude positiva do parceiro frente a } \\
\text { aposentadoria precoce; Condição financeira }\end{array}$ \\
\hline Hintsa et al. & Finlândia - 2015 & Condições de trabalho estressantes \\
\hline Venti, Wise & USA - 2015 & $\begin{array}{l}\text { Nível educacional (que afeta indiretamente } \\
\text { saúde, rendimentos e emprego). }\end{array}$ \\
\hline Korhonen et al. & Finlândia - 2015 & $\begin{array}{l}\text { Tabagismo e uso excessivo de álcool predizem } \\
\text { aposentadoria por invalidez }\end{array}$ \\
\hline Kaila-Kangas et al. & Finlândia - 2015 & $\begin{array}{l}\text { Indivíduos que abandonaram o vício da bebida } \\
\text { e aqueles com transtornos por uso de álcool } \\
\text { apresentavam risco maior de incapacidade para } \\
\text { o trabalho. }\end{array}$ \\
\hline Demou et al. & $\begin{array}{l}\text { Reino Unido - } \\
2017\end{array}$ & $\begin{array}{l}\text { Auto avaliação de saúde ruim dependente do } \\
\text { status socioeconômico; Gênero: Homens: auto } \\
\text { avaliação de saúde ruim, problemas com saúde } \\
\text { mental e sedentarismo; Mulheres: auto } \\
\text { avaliação de saúde ruim, problemas com saúde } \\
\text { mental, pelo menos uma doença crônica, } \\
\text { fumantes e sedentárias }\end{array}$ \\
\hline
\end{tabular}

A aposentadoria foi inicialmente implantada no final do século XIX com o projeto de assegurar o sustento e uma vida digna aos trabalhadores quando afastados do mercado de trabalho, seja por doença, invalidez ou pela idade avançada. Nesse contexto, os sistemas previdenciários tinham essa função em comum, diferindo de uma sociedade para outra em termos de formação e desenvolvimento, influenciados por fatores políticos, econômicos, culturais e sociais (Fontoura, Doll, Oliveira, 2015; Batich, 2004). 
Nos países desenvolvidos, os sistemas previdenciários são compostos por dois pilares, um de caráter redistributivo e o outro baseado em uma tríade que envolve o histórico salarial, o número de contribuições e a idade de solicitação da aposentadoria. A natureza dos programas varia entre repartição e capitalização, sendo que na maioria dos países é o governo que centraliza uma considerável parcela das contribuições. As projeções indicavam queda no valor médio dos benefícios e como consequência, o endurecimento das regras de concessão desses benefícios em todos os países membros (Ferreira, 2007).

Desde 2015, a Organização para a Cooperação e o Desenvolvimento Econômico (OCDE) registrou redução no ritmo das reformas nos regimes previdenciários relacionado a melhorias nas finanças públicas, que aliviaram as pressões nesses sistemas. Contudo, as preocupações com a sustentabilidade financeira continuam a chamar a atenção dos países dado ao acelerado processo de envelhecimento, as desigualdades durante a vida profissional e as mutações do trabalho. Nesse contexto, os incentivos à aposentadoria antecipada que foram implementados em vários países até a década de 90 estão sendo revistos e vem sofrendo mudanças estruturais dado ao risco de esgotamento desses sistemas de seguridade social (OCDE, 2017; Garcia, Fontainha, Passos, 2017).

Nos últimos anos, os países membros da OCDE vêm mudando as idades para a concessão da aposentadoria, dos benefícios, contribuições ou incentivos fiscais. Seguindo a legislação, a idade normal para a aposentadoria aumentou cerca de 1,5 anos para homens e 2,1 anos para as mulheres, com estimativas de alcançar 66 anos em 2060. Com isso, a vida profissional aumentará para 68 anos na Dinamarca, Itália e Holanda. Por outro lado, a idade normal de aposentadoria permanecerá abaixo de 65 anos na França, Grécia, Luxemburgo, Eslovênia e Turquia para trabalhadores em plena carreira (OCDE, 2017).

Na América Latina e Caribe (ALC) o maior desafio enfrentado pela política previdenciária moderna, está relacionado à baixa cobertura dos planos formais de aposentadoria, tanto em relação ao número de trabalhadores que contribuem com esse sistema quanto aqueles indivíduos que recebem algum tipo de renda derivada de aposentadorias não contributivas, as chamadas aposentadorias sociais (OCDE, 2015).

A cobertura ativa (pagas por trabalhadores inscritos em regimes previdenciários obrigatórios) é baixa, sendo que, a cada 100 trabalhadores, em média, 45 deles 
efetuam contribuição ao sistema, número este que não sofreu aumento significativo mesmo após as mudanças propostas com as reformas previdenciárias locais. Esse baixo nível de contribuição está relacionado a uma série de características socioeconômicas, entre elas educação (quanto maior nível de escolaridade, maior a contribuição), gênero (taxa média da participação feminina no mercado de trabalho é de $56 \%$ para mulheres e $83 \%$ para homens) e renda (pessoas com maior renda tendem a contribuir mais em relação aos de baixa renda) (OCDE, 2015).

Além disso, o tipo de ocupação é outro fator determinante da cobertura dos sistemas previdenciários na ALC, sendo que a cada 100 profissionais, 64 assalariados e apenas 17 autônomos contribuem para os fundos de pensão. As mudanças frequentes entre formalidade, informalidade e inatividade proporcionam grandes lacunas que podem pôr em risco os rendimentos futuros da aposentadoria, por conta de históricos incompletos de contribuição e redução dos direitos previdenciários ao longo do tempo (CEPAL, 2018; OCDE, 2015).

As aposentadorias sociais vêm aumentando ao longo dos anos e já podem ser consideradas elemento central no sistema previdenciário em alguns países, nos quais Guiana, Bolívia, Venezuela e Brasil encontram-se entre os mais generosos com esse tipo de cobertura previdenciária (OCDE, 2015).

Para a Comissão Econômica para a América Latina e Caribe (CEPAL), diante de um cenário de incerteza econômica, transformações no mundo do trabalho e um ciclo de fraco crescimento na região, as políticas que envolvem a proteção social, o mercado de trabalho e os sistemas previdenciários devem ser reforçadas com vistas a alcançar um desenvolvimento sustentável com igualdade para todos (CEPAL, 2018).

O Sistema Previdenciário Brasileiro tem seu marco legal por meio da promulgação do Decreto-Lei n 4.682, de 24 de janeiro de 1923, conhecida como Lei Eloy Chaves, que instituiu a criação da primeira Caixa de Aposentadorias e Pensões (CAP) para os trabalhadores das empresas ferroviárias (Rangel et al., 2009).

As mudanças no Sistema Previdenciário Brasileiro estão apresentadas na Tabela 03: 
Tabela 03 - Evolução histórica do Sistema Previdenciário Brasileiro. São Paulo, 2019

\begin{tabular}{ll}
\hline Previdência Social ganha o interesse dos trabalhadores e Estado. \\
Agrupamento das CAPs em grandes Institutos de Aposentadoria e Pensão (IAPS) \\
que asseguravam cobertura a empregados do meio urbano, trabalhadores \\
autônomos e dependentes, mantendo vínculo com a categoria ocupacional.
\end{tabular}

1960

Promulgação da Lei Orgânica da Previdência Social (Lops) com a unificação institucional e dos planos de benefício.

1966

Criação do Instituto Nacional de Previdência Social (INPS), que assumiu os benefícios previdenciários e assistência médica para todos os profissionais urbanos formais, exceto os servidores públicos e empregados domésticos.

Cobertura restrita foi estendida aos trabalhadores domésticos (1972) e aos autônomos.

1970 Criação de benefícios de assistência social para idosos e inválidos que não recebiam outro benefício social e mantinham renda per capita inferior a um quarto do salário mínimo.

Expansão da cobertura previdenciária trabalhadores rurais com 65 anos ou mais de idade e inválidos em qualquer idade.

Criação do Fundo de Assistência ao Trabalhador Rural (Funrural), sujeito ao Ministério do Trabalho e Previdência Social.

1977

Promulgação da Lei no 6.435 com a definição de diretrizes básicas para o desenvolvimento do sistema previdenciário privado, na qual essas instituições poderiam operar apenas sobre o regime de capitalização.

Promulgação Constituição Federal (CF) - Constituição Cidadã - em 1988

Introdução de um conceito mais inclusivo de seguridade social

Década de 80

Estabelecido um orçamento único em todo o sistema de seguridade para o financiamento das ações em saúde, previdência e assistência, cuja provisão advém das contribuições sobre os salários, do Programa de Integração Social (PIS) e da Contribuição para o Financiamento da Seguridade Social (Cofins) entre outras fontes.

1999

Promulgação da Lei no 9.876 que estipulou o fator previdenciário (FP) e aumentou o período de referência para o cálculo do valor do benefício. A finalidade do FP era desestimular aposentadorias precoces.

Nova Emenda Constitucional (EC) no 41 igualou o Regime Geral da Previdência

Social (RGPS) ao Regime Próprio de Previdência Social (RPPS) reconhecendo que não existem motivos técnicos, políticos ou jurídicos para a diferenciação dos regimes. Esta igualdade, porém, só se concretizou em 2013.

Promulgação da Lei no 12.618 que instituiu o Regime de Previdência Complementar para os servidores públicos federais exigido na EC $n^{\circ} 41 / 2003$.

2012 e 2013 Passados 10 anos, o regulamento foi aprovado pela Superintendência Nacional de Previdência Complementar (PREVIC) e só é válida para servidores que ingressaram no serviço público após sua promulgação.

2014

Medida Provisória (MP) no 664 que posteriormente foi convertida na Lei no 13.135 que reestruturava as regras de pensão do RGPS, sendo algumas medidas estendidas para os servidores públicos federais.

Promulgação da Lei no 13.183 que criava o fator previdenciário (85/95), 2015 considerado nova alternativa para o cálculo do benefício por tempo de contribuição, sendo desconsiderado quando os postulantes atingissem 85 e 95 anos para mulheres e homens respectivamente.

Fonte: adaptado de Camarano, Fernandes, 2011. 
Com a promulgação da CF em 1988, a Previdência Social (PS) foi inserida em um sistema de proteção mais amplo, a Seguridade Social, definida como "conjunto integrado de ações de iniciativa dos Poderes Públicos e da sociedade, destinados a assegurar os direitos relativos à saúde, à previdência e à assistência social" (Artigo 194, Brasil, 2016). Assim, passa a ser considerada um direito social fundamental e assume papel de destaque na renda dos trabalhadores ativos ou inativos (Nolasco, 2012; Rangel et al., 2009).

Atualmente a PS é constituída por três diferentes regimes: o RGPS, o de maior proporção, que compreende os trabalhadores da iniciativa privada, possui caráter contributivo e filiação obrigatória; o RPPS que assegura cobertura aos servidores públicos efetivos, onde cada Estado tem autonomia sobre o seu regime e, por fim, o Privado, considerado complementar, de adesão facultativa (Camarano, Fernandes, 2011).

Os requisitos necessários para que o indivíduo se aposente pelo RGPS estão ligados a idade e ao tempo de contribuição, sendo que até o presente, para o sexo masculino são necessários 35 anos de contribuição e 65 anos de idade e, para o sexo feminino 30 anos de contribuição e 60 anos de idade. Vale destacar que para professores do magistério infantil ao ensino médio, trabalhadores rurais de ambos os sexos e para aqueles que trabalham em regime de economia familiar é assegurado redução de cinco anos para a idade limite para a aposentadoria (Martins, 2016).

Recentemente, o governo brasileiro apresentou uma Proposta de Emenda à Constituição (PEC) nº 06 em fevereiro de 2019, na qual prevê a idade mínima de aposentadoria para 65 e 60 anos para o sexo masculino e feminino respectivamente e traz como premissas a garantia da sustentabilidade financeira presente e futura da Previdência Social, propõe regras de transição a fim de garantir os direitos já adquiridos pelos trabalhadores e busca por meio desta reforma à harmonização dos direitos previdenciários (entre eles o alinhamento das regras de idade entre os diferentes regimes de aposentadoria), baseados na experiência dos países desenvolvidos que já enfrentaram suas transições demográficas (Brasil, 2019).

Em relação as alterações das disposições constitucionais, a PEC 06/2019 propõe, em seu artigo 115:

O novo regime de Previdência Social de que tratam o art. 201-A e o $\S 6^{\circ}$ do art. 40 da Constituição será implementado alternativamente ao Regime Geral de Previdência Social e aos regimes próprios de previdência social e adotará, dentre outras, as seguintes diretrizes: 
- Capitalização em regime de contribuição definida, admitido o sistema de contas nacionais;

- Garantia de piso básico, não inferior ao salário-mínimo para benefícios que substituam o salário de contribuição ou o rendimento do trabalho, por meio de fundo solidário, organizado e financiado nos termos estabelecidos na lei complementar de que trata o art. 201-A da constituição;

- Gestão das reservas por entidades de previdência públicas e privadas, habilitadas por órgão regulador, assegurada a ampla transparência dos fundos, o acompanhamento pelos segurados, beneficiários e assistidos dos valores depositados e das reservas, e as informações das rentabilidades e dos encargos administrativos;

- Livre escolha, pelo trabalhador, da entidade ou da modalidade de gestão das reservas, assegurada a portabilidade;

- Impenhorabilidade, exceto para pagamento de obrigações alimentares;

- Impossibilidade de qualquer forma de uso compulsório dos recursos por parte de ente federativo;

- Possibilidade de contribuições patronais e do trabalhador, dos entes federativos e do servidor, vedada a transferência de recursos público (Brasil, 2019 p. 13).

De acordo com o Governo Brasileiro, a capitalização surge como modelo de poupança individual de cada trabalhador, com depósitos mensais e proporciona ao contribuinte definir o valor de sua aposentadoria que poderá ser alcançado mediante o plano de contribuições. Esse modelo difere do modelo atual de repartição, na qual a contribuição do trabalhador não vai para uma conta individual, mas sim para garantir o benefício de quem já se aposentou (Brasil, 2019).

O modelo de capitalização se mostrou insustentável nos países onde foi adotado, como exemplo Chile, México, Peru entre outros, além de ser constituir uma alternativa com custo fiscal elevado, de difícil aprovação política e que gera implicações macroeconômicas relevantes. Nesse contexto, a substituição do sistema de repartição pelo capitalizado torna explícita uma dívida do sistema previdenciário anterior, antes implícita, relacionado ao valor atual dos benefícios que trabalhadores e aposentados adquiriram do velho sistema, e recai sobre o governo o financiamento dessa dívida (Holland, Málaga, 2018; Barreto, Oliveira, 2001).

$\mathrm{Na}$ proximidade com a aposentadoria, a mistura de sentimentos pode gerar conflitos pessoais, como medo da solidão, instabilidade financeira e aparecimento de doenças, ligados ao desconhecimento das pessoas em lidar com mudanças ocasionadas pela ruptura do trabalho. Nesse contexto, a transição trabalhoaposentadoria pode ser facilitada por meio de ações organizacionais que promovam, de forma antecipada, a adoção de medidas facilitadoras de bem-estar, como avanços 
na educação e na aquisição de novas habilidades, adaptações no trabalho, aumento no rendimento mensal e, por fim, o fortalecimento dos vínculos sociais, afetivos e familiares os fatores de risco (França, Soares, 2009; Rodrigues et al., 2005).

Assim, compreender as questões relativas à saúde, bem-estar, estilo de vida e as circunstâncias econômicas, sociais e culturais desses idosos trabalhadores configura-se o passo inicial para a formulação de políticas públicas e intervenções nas organizações de trabalho, que apoiem aqueles que pretendem continuar ou sair do mercado laboral, dando continuidade às suas vidas e buscando novas oportunidades para seguir (Demou et al., 2017). 


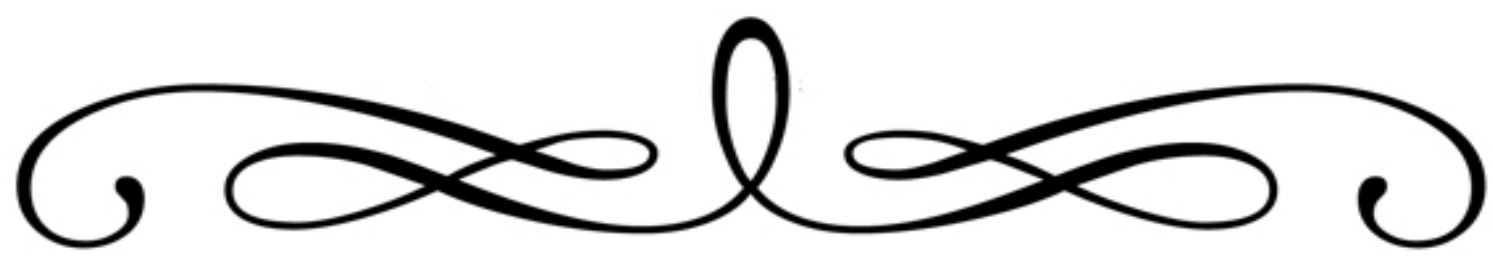

2 JUSTIFICATIVA

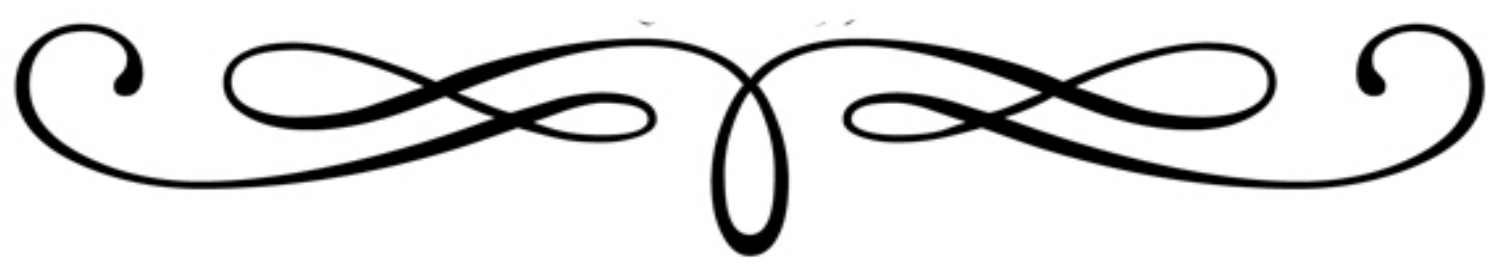




\section{JUSTIFICATIVA}

$\mathrm{Na}$ sociedade contemporânea, é crescente a preocupação com as consequências da transição demográfica sobre o desenvolvimento do país.

As flutuações na economia mundial, os custos esperados com o envelhecimento da população e o risco de escassez de mão-de-obra levantam inquietações sobre como atender as necessidades dos idosos, sobretudo na criação de oportunidades para sua inserção e permanência no mercado de trabalho (Lundgren, Liliequist, Sjöstedt Landén, 2018, Tang et al., 2018, Axelrad, Sabbath, Hawkins, 2017, Settels, McMullin, 2017).

Entre 1970 e 1995, a população economicamente ativa (PEA) brasileira total superava em seis vezes o número de indivíduos com idade igual ou superior a 60 anos. Com o avanço do processo de envelhecimento, esta relação vem diminuindo de forma expressiva, sendo que, em 2050 haverá uma pessoa idosa para cada 1,4 indivíduo de 15-59 anos (Alves, Vasconcelos, Carvalho, 2010).

Segundo esses autores, diante de uma razão tão premente os sistemas previdenciários sofrerão evidente pressão e temas referentes ao financiamento, sustentabilidade financeira e idade de aposentadoria deverão ser consideradas como urgentes nas pautas de discussão governamentais.

A PNAD Contínua do primeiro trimestre de 2017 revelou que os idosos representam $7,3 \%$ das pessoas ocupadas, com maior participação nas regiões Sudeste e Sul. Na comparação entre 2016 e 2017, as pessoas com 60 anos e mais apresentavam tendência de aumento na participação na população ocupada (IBGE, 2018)

Essa tendência foi confirmada no segundo semestre de 2018, revelando que $7,9 \%$ dos idosos brasileiros estão ocupados, dos quais $20,3 \%$ residem na região Sudeste (IBGE, 2018).

Assim é possível perceber que, cada vez mais, idosos estarão no mercado de trabalho, distanciando-se do imaginário social que espera, de forma geral, que a chegada dos 60 anos seja sinônimo de afastamento do mundo laboral e consequente aposentadoria (Paolini, 2016; Ramos et al., 2008). 
Esse novo perfil da população requer ações efetivas do Estado e da sociedade para a garantia de seus direitos fundamentais, inclusive o direito ao trabalho, já previsto no Estatuto do Idoso (Lei $n^{\circ} 10.741$, de $1^{\circ}$ de outubro de 2003) (Brasil, 2006a) e na Política Nacional de Saúde da Pessoa Idosa (Portaria 2.528 de 19 de outubro de 2006) (Brasil, 2006b).

Nesse contexto, é importante destacar que o trabalho é um fator econômico determinante sobre o envelhecimento ativo (OMS, 2005), demonstrando a necessidade de ampliar o apoio acerca da contribuição ativa e produtiva dos idosos nos diferentes segmentos do mercado laboral, considerando a proteção significativa que o trabalho exerce nas perdas funcionais e psicoemocionais dos idosos (Dantas et al., 2017; Amorim, Salla, Trelha, 2014; D’Orsi et al., 2011).

Do mesmo modo, compreender a importância da aposentadoria é fundamental para perceber o comportamento e a maneira como as pessoas reagem aos objetivos das leis e políticas para sua efetivação. A posição de aposentado era associada à passividade, sedentarismo e atualmente pode ser conectada a valores mais positivos, como o reingresso no trabalho e a possibilidade de novos aprendizados (Lundgren, Liliequist, Landén, 2018).

Dessa forma, é primordial o comprometimento e esforço de todos os atores sociais envolvidos com as temáticas com vistas a criar soluções que considerem a reinserção, a permanência do idoso no ambiente laboral e as novas oportunidades da aposentadoria, respeitando sua condição física, mental, social, interesse e motivação de cada idoso (McDonald et al., 2015; Foguel, Normanha Filho, 2006).

O aumento da expectativa de vida requer, no setor saúde, estratégias voltadas a melhorias nas condições de acesso aos serviços e no desenvolvimento de propostas políticas que enfatizem o envelhecimento ativo e saudável. Nesse contexto, os profissionais de saúde, especialmente os enfermeiros, necessitam estar preparados para ouvir, acolher e responder às necessidades físicas, psicoemocionais e culturaus, alainhados aos princípios e diretrizes do SUS (Castro et al., 2018; Barros,Machado, 2012).

Sendo assim, estudos que enfatizam conteúdos sobre trabalho e aposentadoria tornam-se relevantes sob o ponto de vista socioeconômico (previdenciário, trabalhista), familiar e de saúde, ao consideramos o aumento expressivo na expectativa de vida, déficit de renda da aposentadoria e a maior participação de idosos no mercado de trabalho no atual cenário político brasileiro. 
Este estudo se propôs a buscar novos dados que possam auxiliar na formulação de políticas públicas e organizacionais de incentivo à participação dos idosos no mercado de trabalho ou de preparação para sua aposentadoria, de acordo com seus desejos e necessidades.

Dessa forma, é possível promover o envelhecimento saudável, com qualidade de vida, igualdade de direitos, maior respeito e reconhecimento a essa população. 


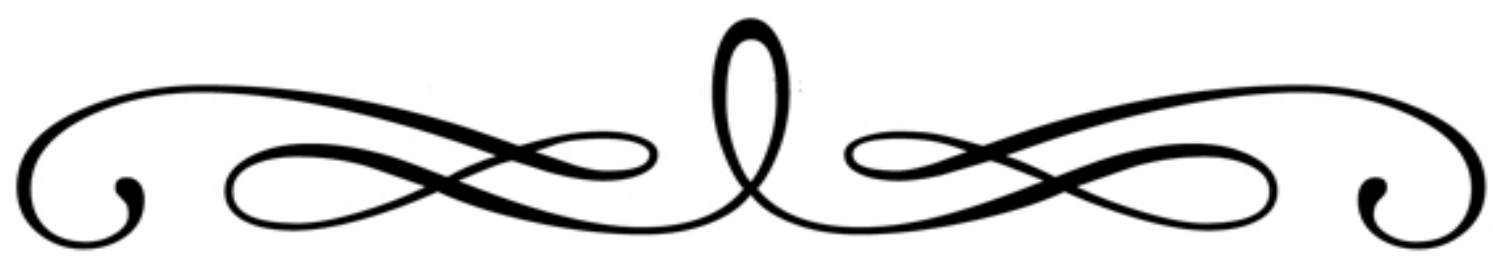

3 MARCO TEÓRICO

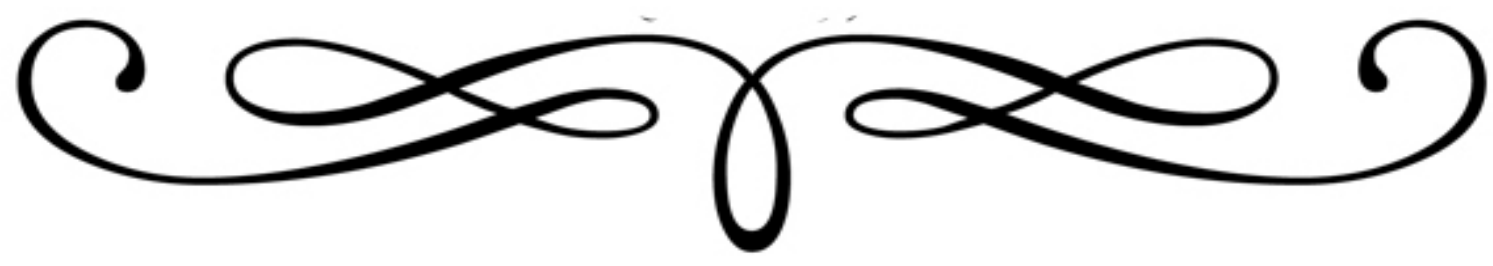




\section{MARCO TEÓRICO}

\subsection{TEORIA DAS REPRESENTAÇÕES SOCIAIS}

A opção pela Teoria das Representações Sociais (TRS) como aporte teórico para análise dos dados ocorreu por este referencial condicionar a construção de um saber prático que considera as influencias sociais, históricas e culturais dos indivíduos, sendo oportuna e interessante para estudar a problemática do idoso no mercado de trabalho na modernidade (Ferreira et al., 2010; Padilha, Silva, Coelho, 2007).

Com o estudo "La psychanalyse, son imagem et son public", Serge Moscovici revolucionou o aspecto conceitual da investigação dos fenômenos sociais ao afirmar que o senso comum não é uma banalização do saber científico, mas sim, uma forma de conhecimento adaptado a diferentes necessidades, inseridas em contextos específicos, com critérios preestabelecidos (Moreira et al., 2015; Santos, 2013; Azevedo, Miranda, 2012).

Representar significa desvelar um significado, muitas vezes inconsciente e subjetivo, que uma pessoa tem de algum objeto ou situação. É reapresentar a realidade, estando esta interiorizada e reconstruída no sistema cognitivo e de valores das pessoas e grupos, determinados pelo contexto histórico, social e ideológico dos mesmos (Moreira et al., 2015).

Nesse sentido, o vínculo com o objeto é de natureza intrínseca e deve ser compreendido dentro do nexo social, considerando o sujeito como ator social ativo bem como seus processos simbólicos de condutas e comportamentos que podem ser afetados por diferentes aspectos da vida cotidiana (Moscovici, 2012; Jodelet, 2009; Moscovici, 2005).

As Representações Sociais (RS) ilustram as relações complexas, reais e imaginárias, objetivas e simbólicas que o indivíduo mantém com o objeto, traduzidas por meio de um sistema organizado e estruturado que tem como finalidade a apreensão e controle da realidade, a fim de permitir sua compreensão e interpretação. Dessa forma, pode-se assumir que os indivíduos não estabelecem seus pensamentos 
de maneira isolada, mas influenciados pela vida e objetos que compartilham socialmente e que compõem sua realidade (Morera et al., 2015; Reigota, 1995).

Portanto, as RS equivalem a um conjunto de princípios construídos de forma interativa e compartilhada por diferentes grupos que podem auxiliar na transformação da realidade (Moreira et al., 2015; Reigota, 1995).

As RS moldam o contexto na qual os fenômenos acontecem e podem ser consideradas instrumentos que auxiliam a superar a simples sistematização de fatos ou registro de dados (Fernandes, Andrade, 2016; Moscovici, 2012). Além disso, nos proporcionam definir, interpretar e tomar decisões, de forma conjunta, sobre os aspectos da realidade diária (Jodelet, 1993) e devem ser contempladas como um "esforço constante de tornar comum e real algo que nos pareça incomum ou não familiar" (Moscovici, 2012).

O não familiar são ideias ou ações que nos perturbam ou, de certa forma, nos causam tensão. Essa tensão entre o comum/familiar e incomum/não familiar é constituída nos universos consensuais e sua assimilação pode modificar as crenças do grupo social, na reapresentação do novo (Reis, Bellini, 2011; Moscovici, 2012).

Dessa forma, as RS são elaboradas por meio de dois processos sociocognitivos básicos, a saber: a objetivação e a ancoragem.

A objetivação é a operação imagética e estruturante que transforma noções abstratas em algo concreto, quase tangível e esclarece como os elementos das RS se organizam bem como, o percurso para sua concretude (Jodelet, 1993; Spink, 1993). Assim, as ideias e noções abstratas, objetos da representação, ganham corpo, materialidade e significado. Portanto, objetivar é incorporar um excesso de significações ao materializá-las (Moscovici, 2012; Tateo, lannaccone, 2012; Padilha et al., 2007).

Já a ancoragem é entendida como processo de classificar, encontrar um espaço e nomear alguma coisa, inscrevendo-as em um universo de pensamento já existente (Moscovici, 2012; Jodelet, 2001). Esse processo de significação pode ser compreendido como a fixação da representação em uma dada realidade, atribuindo sentido ao objeto que, por sua vez, passa a ser reelaborado (Moscovici, 2012; ArayaUmaña, 2002)

A objetivação e a ancoragem são consideradas procedimentos fundamentais para a geração e o funcionamento das RS. Por meio de uma relação dialética, são capazes de tornar inteligível a realidade, resultando em um conhecimento social, 
prático e funcional que favorece o desenvolvimento das situações e relações que estão presentes na vida dos indivíduos (Moreira et al., 2015).

Ultimamente, a TRS se faz presente nos diferentes campos de conhecimento das ciências humanas, sociais e, na Enfermagem vem sendo apontada como importante referencial teórico para o desenvolvimento de pesquisas que tomam por base o saber popular e que visam identificar os objetos de representação num determinado contexto social (Duarte et al., 2009; Marques et al., 2006). 


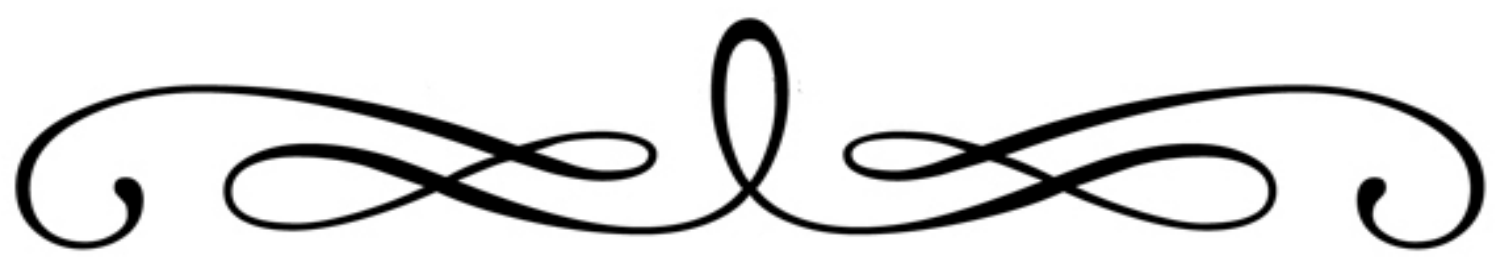

4 OBJETIVOS

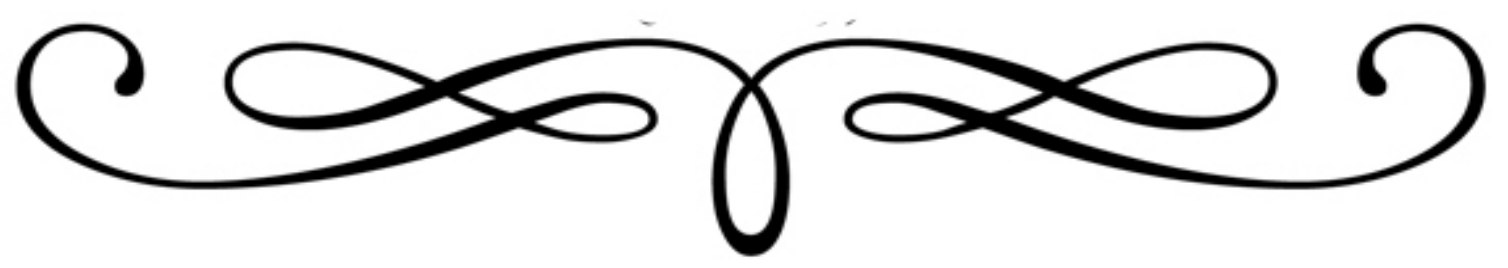




\section{OBJETIVOS}

\subsection{OBJETIVO GERAL}

- Identificar e analisar os significados de trabalho e aposentadoria para o idoso jovem.

\subsection{OBJETIVOS ESPECÍFICOS}

- Caracterizar o perfil sociodemográfico, condição de saúde e a condição de trabalho e ocupação dos idosos jovens moradores de uma cidade no Sul de Minas e no município de São Paulo;

- Identificar os significados do trabalho e aposentadoria para estes idosos jovens;

- Explorar convergências e divergências nos discursos dos idosos jovens das duas cidades eleitas em relação ao significado de trabalho e aposentadoria. 


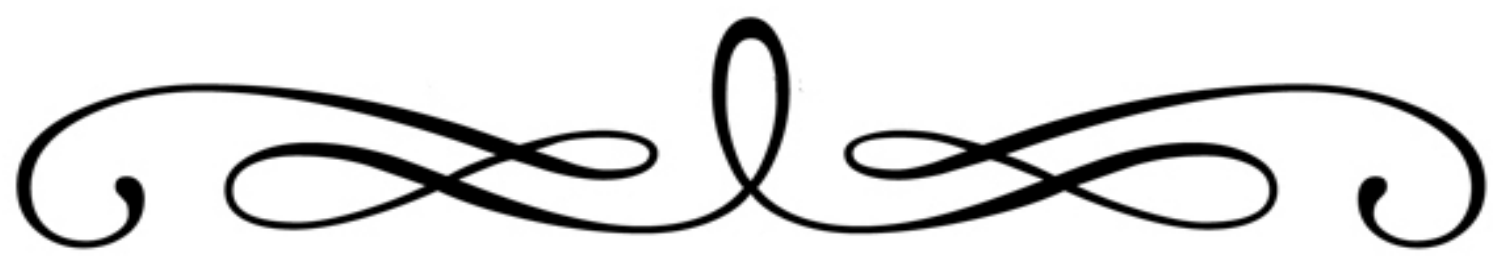

5 PRESSUPOSTOS

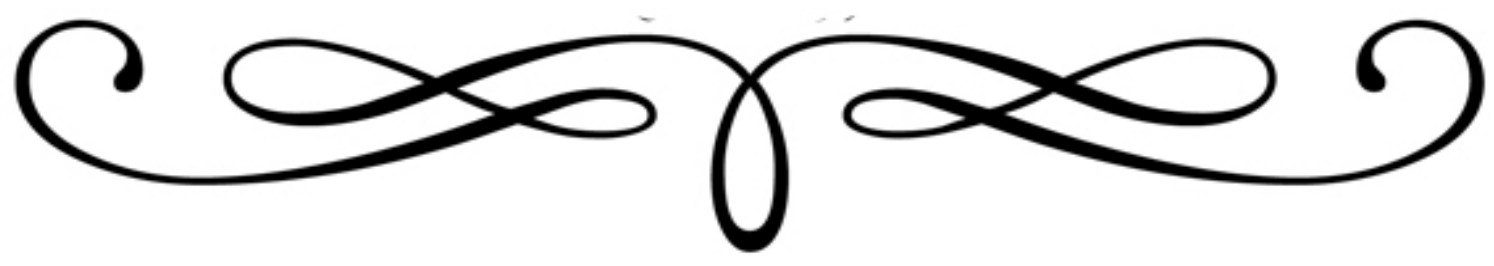




\section{PRESSUPOSTOS}

- O trabalho é percebido para uns como meio de realização pessoal e profissional e para outros como necessidade para prover o sustento familiar.

- A transição entre trabalho e aposentadoria gera dificuldades na tomada de decisão e requer atitudes individuais para adaptação à rotina.

- A aposentadora permite desenvolver planos ou projetos de vida relegados no passado em decorrência da necessidade do trabalho. 


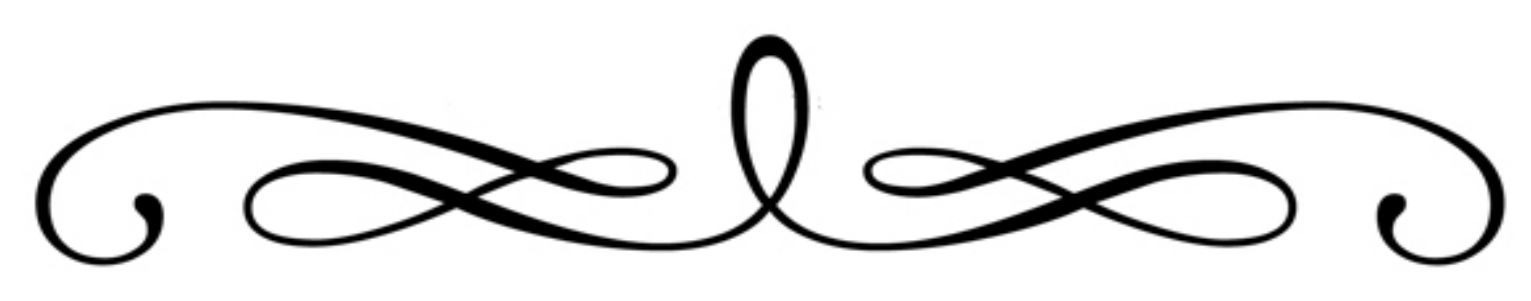

6 PERCURSO METODOLÓGICO

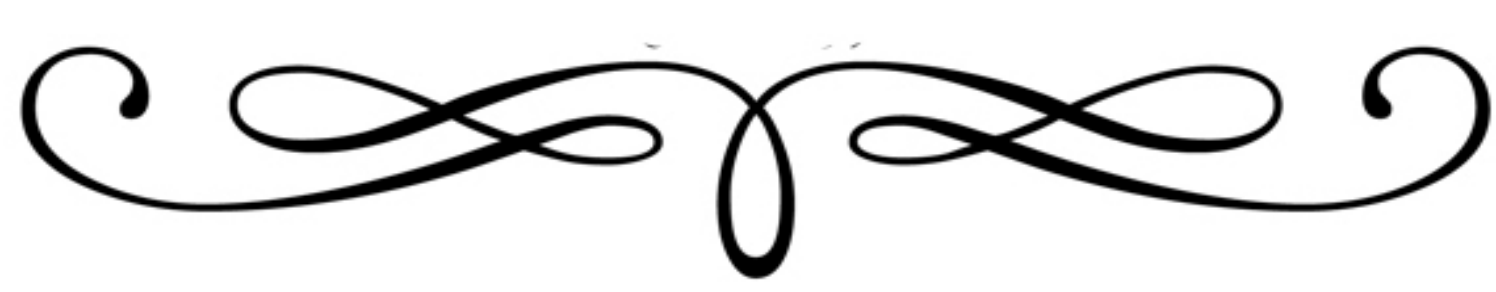




\section{PERCURSO METODOLÓGICO}

\subsection{TIPO DE ESTUDO}

Estudo prospectivo, observacional e exploratório de abordagem quantiqualitativa, que empregou as Representações Sociais como referencial teórico e seguiu as orientações do Consolidated Criteria for Reporting Qualitative Research (COREQ) para garantir maior qualidade na descrição do caminho percorrido para sua realização.

Os métodos quantitativos tem como objetivo demonstrar dados, indicadores e tendências observáveis ou produzir modelos teóricos de alta abstração com aplicabilidade prática e o método qualitativo estuda a história, as relações, representações, crenças, percepções e opiniões, resultantes da interpretação que os indivíduos fazem a respeito de como vivem, constroem seus significados e a si mesmos, sentem e pensam (Minayo, 2006).

A pesquisa qualitativa tem como características estudar o significado da vida em suas condições reais, representar as opiniões e perspectivas das pessoas, compreender o contexto de vida e pode revelar conceitos existentes ou emergentes no imaginário social, auxiliando na compreensão do comportamento dos indivíduos no cotidiano (Yin, 2016).

Portanto, o conjunto de dados originados das duas abordagens não são dicotômicos, mas sim, complementam um ao outro de forma dinâmica, promovendo a construção da realidade mais elaborada e completa, buscando o desenvolvimento de novas teorias e técnicas cooperativas (Minayo, 2006;1994), o que auxiliou a desvelar a complexidade da temática na atualidade.

Entende-se que, para trabalhar com a temática do idoso no mercado de trabalho e bem como sua aposentadoria é necessário um enfoque mais amplo para capturar com maior riqueza a vida, as crenças, os hábitos e costumes das pessoas. Por isso, elegeu-se o trabalhar com os dois métodos, quantitativo e qualitativo.

Nesse sentido, este estudo buscou entrar no mundo vida dos participantes, facilitando a construção de uma realidade mais elaborada e completa do fenômeno estudado, considerando o contexto atual (Minayo, 2006;1994; Yin, 2016). 


\subsection{CENÁRIOS DO ESTUDO}

Buscou-se captar diferentes percepções sobre trabalho e aposentadoria, considerando as variantes econômicas, sociais e culturais existentes entre as duas cidades e por isto, este estudo foi realizado em dois cenários, na cidade de Campos Gerais - MG (Comunidade A) e na região metropolitana de São Paulo -SP (Comunidade B). A escolha por Campos Gerais foi decorrente de o fato do pesquisador ter sido morador da cidade desde sua infância e ter acompanhado o envelhecimento da população. Já São Paulo foi escolhida pelo contato do pesquisador com um grupo de idosos vinculados à Igreja Metodista de Pinheiros, o qual chamou a atenção pelo número de idosos que participavam, diariamente, das atividades propostas pelo grupo.

Localizada no sul de Minas Gerais, Campos Gerais tem população estimada em 28.7023 habitantes distribuídos em uma área total de $769,504 \mathrm{~km}^{2}$ com Índice de Desenvolvimento Humano (IDH) de 0,682 em 2010 (IBGE, 2019a).

O Produto Interno Bruto (PIB) em 2016 atingiu o valor de $\mathrm{R} \$ 483.899,44$ resultante das diferentes atividades econômicas do município sobretudo a agropecuária e o setor de serviços (administração, defesa, educação, saúde pública e seguridade social. No mesmo ano, a população ocupada era de $10,9 \%$ do total de pessoas, com média de 1,7 salários mínimos para os trabalhadores formais (IBGE, 2019a).

A população idosa de Campos Gerais é composta por 3322 indivíduos dos quais 1886 encontram-se na faixa etária entre 60 e 69 anos (Tabela 04).

São Paulo (SP), cidade mais populosa do país, apresentava no censo de 2010 uma população total de 11.253 .503 indivíduos. Conta com $1.521,110 \mathrm{~km}^{2}$ de área territorial e IDH de 0,805 (IBGE, 2019b).Com um PIB de $\mathrm{R} \$ 687.035 .889,61$ registrado em 2016, SP se destaca no setor de serviços e indústria. O salário médio mensal dos trabalhadores formais era de 4,2 e $46,8 \%$ da população encontrava-se ocupada em 2016 (IBGE, 2019b).

A população idosa dos dois cenários está apresentada na Tabela 04. 
Tabela 04 - População idosa por faixa etária e sexo, segundo município de origem. São Paulo, 2019

\begin{tabular}{lcccccc}
\hline \multirow{2}{*}{$\begin{array}{c}\text { Faixa etária } \text { Sexo } \\
\text { S }\end{array}$} & \multicolumn{3}{c}{ Campos Gerais - MG } & \multicolumn{3}{c}{ São Paulo - SP } \\
\cline { 2 - 7 } & Homens & Mulheres & Total & Homens & Mulheres & Total \\
\hline 60 a 64 anos & 545 & 493 & 1038 & 183.012 & 240.043 & 423.055 \\
65 a 69 anos & 415 & 433 & 848 & 127.020 & 175.316 & 302.336 \\
70 a 74 anos & 297 & 273 & 570 & 95.214 & 142.087 & 237.301 \\
75 a 79 anos & 203 & 233 & 436 & 64.324 & 106.645 & 170.969 \\
80 a 84 anos & 132 & 136 & 268 & 41.305 & 78.206 & 119.511 \\
85 a 89 anos & 47 & 63 & 110 & 17.737 & 39.468 & 57.205 \\
90 a 94 anos & 20 & 21 & 41 & 5.877 & 15.357 & 21.234 \\
95 a 100 anos & 03 & 06 & 9 & 1.270 & 4.228 & 5.498 \\
100 anos e mais & 00 & 02 & 2 & 247 & 780 & 1.027 \\
\hline \multicolumn{1}{c}{ TOTAL } & $\mathbf{1 6 6 0}$ & $\mathbf{1 6 6 2}$ & $\mathbf{3 3 2 2}$ & $\mathbf{5 6 3 . 0 0 6}$ & $\mathbf{8 0 2 . 1 3 0}$ & $\mathbf{1 . 3 3 8 . 1 3 6}$ \\
\hline
\end{tabular}

Fonte: IBGE, $2019(a, b)$

O número de idosos em São Paulo ultrapassa um milhão de pessoas, dos quais 725.391 têm idade entre 60 e 69 anos (Tabela 04). Chama atenção que a partir dos 70 anos, o número de mulheres idosas é quase o dobro dos homens.

Considerando a dimensão da região metropolitana de São Paulo, optou-se por iniciar a coleta de dados em um projeto para idosos na qual o pesquisador já mantinha contato anterior.

O Projeto Social Samuel Rangel, de cunho social, é desenvolvido pela Igreja Metodista de Pinheiros desde 1998 e mantém convênio com a Prefeitura Municipal de São Paulo.

O projeto oferece atividades culturais e recreativas para os 120 idosos, de todas as idades, incluindo oficinas de pintura em tecido, crochê, tricô, ponto cruz, artesanato, informática além de atividades físicas como alongamento e fisioterapia (Igreja Metodista, 2016). 


\subsection{PARTICIPANTES}

Foram selecionados para este estudo idosos jovens, ou seja, com idade entre 60 e 70 anos, aposentados ou não, residentes nos munícipios selecionados, de ambos os sexos, com qualquer nível de instrução, capazes de responder a entrevista e que aceitassem participar da pesquisa mediante assinatura do Termo de Consentimento Livre e Esclarecido (TCLE) (APÊNDICE A).

Como critérios de exclusão foram estabelecidos a impossibilidade para se comunicar verbalmente, a recusa na participação e assinatura do TCLE.

\subsection{INSTRUMENTOS PARA COLETA DE DADOS}

O formulário utilizado para a coleta de dados foi elaborado em duas partes, de forma colaborativa entre pesquisador e orientador, sendo testado previamente para otimizar a coleta e reduzir possíveis erros de compreensão.

A primeira parte do formulário (APÊNDICE B), contendo 16 questões que versavam sobre as características socioeconômicas e de trabalho além de nove que questionavam a condição de saúde dos participantes A segunda parte abarcava questões norteadoras que tinham o objetivo de promover reflexões dos participantes e colher seus depoimentos sobre os significados de trabalhar e estar aposentado.

Para cada indivíduo foram aferidas informações como idade, sexo, estado civil, cor autodeclarada, religião, escolaridade, tipo de moradia, número de dependentes de renda, arranjo familiar, situação atual de trabalho, capacidade de trabalho auto referida, absenteísmo no trabalho, participação em atividades sociais, autopercepção de saúde, uso de álcool e tabaco, plano de saúde, uso de medicamento, quantidade diária e forma de aquisição dos mesmos, internação hospitalar, tratamento odontológico, história de quedas.

A fim de conhecer a capacidade funcional e cognitiva dos participantes, bem como a presença de quadro depressivo foram empregados três instrumentos consagrados e validados, os quais compõem a Avaliação Multidimensional do Idoso.

No Brasil, há diferentes versões e pontos de coorte desses instrumentos utilizados. Dessa forma, adotou-se as versões dos instrumentos e as notas de coorte propostas pelo Ministério da Saúde (Brasil, 2006). São eles: 
- Mini Exame do Estado Mental (MEEM): elaborado nos Estados Unidos da América, publicado por Folstein e seus colaboradores em 1975, traduzido e validado para uso no Brasil em 1994 (Folstein; Folstein; McHugh, 1975; Bertolucci et al,, 1994). Ficou conhecido por ter sido utilizado em relevante estudo epidemiológico nos anos 80 e sua ampla aceitação por profissionais e pela sociedade acadêmica deve-se à praticidade e magnitude da avaliação que realiza (Melo, Barbosa, 2015). A pontuação total é de 30 pontos e as notas de corte são: Analfatabetos: 19; de 1 a 3 anos de escolaridade: 23; 4 a 7 anos de escolaridade: 24 e acima de 7 anos de escolaridade: 28 (Brasil, 2006). (ANEXO A).

- Escala de Lawton: avalia a funcionalidade de nove funções relacionadas a atividades comunitárias e de adaptação ao ambiente, influenciadas pela cognição (Amendola et al, 2014). Em cada questão, a primeira resposta representa independência, a segunda dependência parcial ou capacidade com ajuda e a terceira, dependência. A pontuação máxima é 27 pontos (Brasil, 2006) (ANEXO B)

- Escala de Depressão Geriátrica (EDG-15): versão curta da escala original, elaborada por Yesavage e colaboradores em 1983, a qual foi traduzida e validada no Brasil por Almeida e Almeida em 1999. É composta por 15 perguntas com respostas objetivas que devem ser indagadas na sequencia proposta. Para cada resposta afirmativa, deve-se somar um ponto. Para pontuação entre 0 e 5 se considera o quadro psicológico como normal, entre 6 a 10 é sugestivo de depressão leve e 11 a 15 depressão severa (Brasil, 2006) (ANEXO C).

\subsection{COLETA DE DADOS}

As entrevistas foram realizadas entre novembro de 2018 e janeiro de 2019, utilizando o formulário semiestruturado descrito acima e aconteceram, em sua maioria, na residência dos participantes. Para aqueles matriculados no Projeto Samuel Rangel, os encontros ocorreram em uma sala cedida pela equipe do Projeto. 
A maioria dos participantes foi recrutada pessoalmente $(n=33)$ enquanto 0 restante foi selecionado por manter vínculo com o Projeto Samuel Rangel, da Igreja Metodista de Pinheiros $(n=11)$. O primeiro contato com todos os participantes ocorreu em praças públicas, locais de trabalho, comércio em geral, igrejas, condomínios e via telefone.

Os participantes foram selecionados por conveniência, o desenho mais comum de amostragem não probabilística, que sugere abordar os indivíduos que estão acessíveis, disponíveis e com disposição para responder. O uso dessa técnica representa, como ponto positivo, maior facilidade operacional e baixo custo. No entanto, entre suas limitações encontram-se a falta de representatividade e a impossibilidade de fazer afirmações mais gerais empregando técnicas estatísticas (Uchoa, 2015; Shaughnessy, Zeckmeister, Zeckmeister, 2012).

Este tipo de amostragem vem sendo aplicado em estudos exploratórios e qualitativos, frequentemente utilizados para geração de ideias, hipóteses e insights (Gil, 2011; Marotti et al., 2008).

Em Campos Gerais, foi confeccionada uma lista com idosos conhecidos da família do pesquisador que atendiam aos critérios de inclusão e que, ao serem encontrados pela cidade, aceitaram em participar da pesquisa. Assim, todos foram contatados via telefone para o agendamento da entrevista, realizadas no domicílio dos idosos. Foram convidadas 40 pessoas, no entanto, 22 aceitaram participar.

Em São Paulo, a abordagem aos participantes foi realizada em áreas de circulação do pesquisador e através do contato com o Projeto Samuel Rangel. Foram convidados a participar mais 30 idosos, dos quais 11 aceitaram participar do estudo e, entre os idosos vinculados ao Projeto, dos 15 que se encontravam na faixa etária proposta pelo estudo, 11 permitiram o contato telefônico e o agendamento das entrevistas. Vale destacar que a equipe do Projeto fez um contato inicial com os idosos para depois liberar a lista com os nomes e telefones.

Entre os motivos de recusa, em ambas as cidades, estavam a falta de disponibilidade, o medo em responder as questões e a não aceitação em assinar o TCLE.

Para todos os participantes foi esclarecido, no momento inicial, as razões do pesquisador para realizar esse estudo, bem como seu interesse pela temática. As entrevistas foram gravadas com uso de aparelho digital, com duração média de 30 minutos e as anotações sobre o campo, registradas em um diário ao final dos 
encontros e versavam sobre pontos a serem melhorados na performance do pesquisador.

O formulário e os demais instrumentos foram apresentados aos idosos participantes e, caso surgissem dúvidas, as mesmas eram esclarecidas antes de prosseguir para a assinatura do TCLE. Ao iniciar a entrevista, todos foram comunicados que a mesma estava sendo gravada.

As entrevistas com os casais aposentados foi realizada coletivamente e, em três ocasiões, os participantes foram entrevistados com a presença de terceiros, a saber: marido doente, paciente e filha.

Cada entrevista foi realizada em uma única sessão e as transcrições não foram encaminhadas aos participantes para comentários e/ou correção.

\subsection{ASPECTOS ÉTICOS-LEGAIS}

Os aspectos éticos e legais da pesquisa seguiram as normatizações da Resolução 466/2012 do Conselho Nacional de Saúde (Brasil, 2012), assim, este estudo foi submetido e aprovado pelo Comitê de Ética da Escola de Enfermagem da Universidade de São Paulo sob o número CAAE 79330817,3,0000,5392 (ANEXO 4).

O projeto de pesquisa foi enviado para a Coordenação do Projeto Social Samuel Rangel que, após leitura e discussão com o pesquisador, foi aprovado e autorizado a realização das entrevistas.

Aos idosos jovens que aceitaram participar desta pesquisa, foi informado seu caráter voluntário, o direito ao sigilo, anonimato e a desistência na participação, sem qualquer tipo de prejuízo para os envolvidos. Foi reforçado o não recebimento de valores ou outras iniciativas e solicitado aos mesmos a assinatura do TCLE em duas vias, sendo que uma foi arquivada pela pesquisador e a outra entregue ao participante no ato da entrevista.

Os riscos associados à participação na entrevista relacionavam-se ao desgaste físico e o emocional, onde o participante poderia solicitar o término das atividades a qualquer momento, programar a retomada de sua participação em nova data e horário ou ainda ser encaminhado ao serviço de Psicologia da Unidade de Referência do cenário de estudo. Nenhum encaminhamento foi necessário ao longo da execução do estudo. 


\subsection{ANÁLISE DOS DADOS}

Os dados socioeconômicos e a condição de saúde dos participantes foram armazenados e tabulados em planilha do Microsoft Excel®, sendo analisados por meio de estatística descritiva na qual as variáveis estão exibidas em valores absolutos (n) e relativos (\%) e as quantitativas expressas por meio das medidas de posição e dispersão, ambos apresentados em tabelas.

Os discursos dos idosos jovens foram transcritos na íntegra e analisados por meio do referencial de Análise de Conteúdo de Bardin, organizados da seguinte maneira:

Na pré-análise, realizou-se a organização e a leitura flutuante do material. $\mathrm{Na}$ sequência, passou-se a explorar o material e a confecção de uma planilha contendo os codificadores dos participantes e seus respectivos depoimentos.

A partir daí, foi iniciada leitura exaustiva dos discursos buscando apreender os significados que os idosos jovens atribuíam ao trabalho e a aposentadoria.

A TRS compreende os indivíduos enquanto atores sociais em movimento, pensadores ativos que carregam muito mais que suas ideologias e crenças durante sua interação no cotidiano social e, nesse contexto, suas ideias e concepções estão representadas na realidade (Silva, Gobbi, Simão, 2005). Dessa forma, ao analisar o conteúdo dos discursos dos idosos jovens participantes foi possível identificar as unidades de registro ou os grupos de representação os quais, objetivados, deram origem às categorias centrais da análise.

O anonimato dos participantes foi garantido adotando o código ID para os idosos de Campos Gerais e IDSP para os de São Paulo (APÊNDICE C) ambos seguidos por um número que atribuía a sequência das entrevistas, bem como a situação de trabalho, para fins de identificar convergências e divergências entre os discursos. Os codificadores das participantes estão exibidos na Tabela 05. 


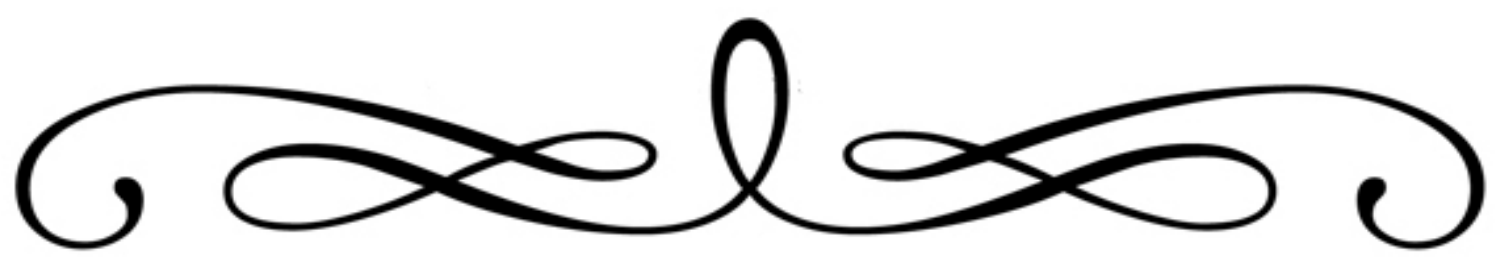

7 RESULTADOS

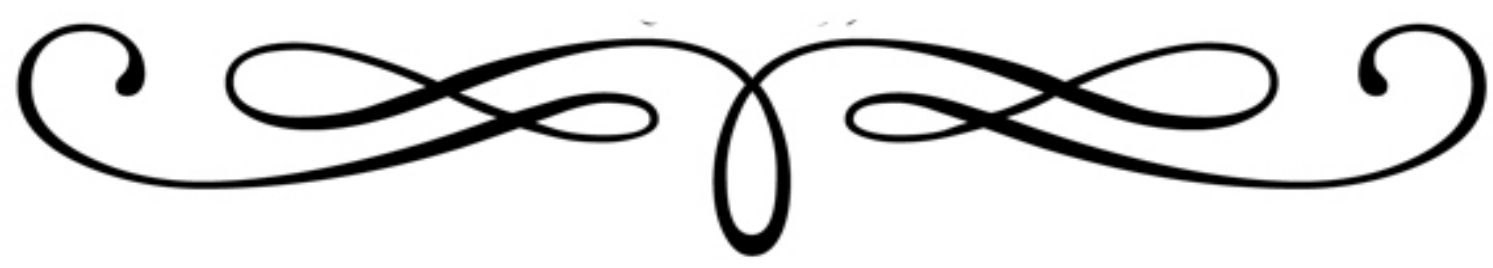




\section{RESULTADOS}

Este estudo contou com a participação de 44 idosos jovens moradores de Campos Gerais - MG (Comunidade A) e da Região Metropolitana de São Paulo (Comunidade B).

Como dito anteriormente, os instrumentos para a realização do rastreio cognitivo, funcional e de humor dos idosos jovens participantes, bem como suas notas de corte foram propostos pelo Ministério da Saúde e extraídos do Caderno de Atenção Básica $\mathrm{n}^{\circ} 19$ - Envelhecimento e saúde da pessoa idosa.

A maioria dos idosos apresentou escores satisfatórios para os três testes. Em relação ao MEEM, 30,5\% $(n=11)$ dos idosos com mais de sete anos de estudo apresentaram escore inferior ao relacionado à sua escolaridade, indicando risco para declínio cognitivo, sendo três idosos do sexo masculino e oito do feminino, com idade entre 64 e 70 anos (APÊNDICE D). Dentre esses idosos, 13,9\% ( $n=5)$ encontravamse em atividades laborais formais.

Em relação à funcionalidade, aferida por meio das atividades instrumentais de vida diária, todos os idosos se mostraram com capacidade preservada, entre os quais $84,1 \%$ atingiram a pontuação máxima do instrumento (APÊNDICE D).

Apenas uma idosa, com 60 anos e mais e de setes anos de escolaridade apresentou indicativo de depressão leve (APÊNDICE D).

Considerando as particularidades das abordagens adotadas para a realização deste estudo, os dados coletados serão apresentados em dois tópicos para facilitar sua exposição. Primeiramente serão apresentados a caracterização das condições socioeconômicas, de trabalho e saúde dos idosos jovens e, em seguida, a contextualização das Representações Sociais sobre trabalho e aposentadoria.

\subsection{CONDIÇÕES SOCIOECONÔMICAS, DE TRABALHO E SAÚDE}

Na população de idosos jovens participantes desta pesquisa, a idade média foi de 66,2 anos (dp: 3,36), destes 63,6\% estavam na faixa etária entre 66 e 70 anos, $68,2 \%$ eram do sexo feminino e $68,2 \%$ casados, houve predomínio $(88,7 \%)$ de idosos 
jovens católicos, para estas variáveis não houve diferença entre as comunidades (Tabela 05). Quanto ao arranjo familiar, a maior parte (84\%) moravam com o esposo e filhos, compartilhando a renda com até quatro pessoas do grupo familiar (36,4\%). Chama atenção que $16 \%$ destes idosos moravam sozinhos e $34,1 \%$ não declaravam dependentes da renda (Tabela 05).

Na comunidade A, havia maior percentual de participantes entre 60 e 65 anos $(40,9 \%)$, solteiros $(4,5 \%)$ e viúvos $(13,7 \%)$, com mais de sete anos de estudo $(91 \%)$, que moravam com o esposo e compartilhavam a renda com até 4 pessoas (41\%). Vale ressaltar que todos os idosos dessa comunidade possuíam casa própria (Tabela 05).

Já na comunidade $B$, os idosos encontravam-se com maior frequência na faixa etária entre 66 e 70 anos, com baixa escolaridade (1 a 3 anos de estudo), residiam em casas alugadas $(13,6 \%)$ e participavam mais de atividades sociais. Observa-se que, na maioria, os idosos não têm dependentes de sua renda e 18,25\% moravam sozinhos e com esposo e filhos $(27,25 \%)$ (Tabela 05$)$.

Pode-se perceber que entre esses idosos jovens, a participação em atividades sociais $(81.8 \%)$ é frequente, sendo maior na comunidade $\mathrm{B}$ e, entre essas atividades, destacam-se as reuniões familiares, grupo de idosos e religiosos, pilates, academia aberta da saúde, hidroginástica, associação de canto, entre outras (Tabela 05).

Tabela 05 - Características socioeconômicas de idosos jovens segundo localidade. São Paulo, 2019

\begin{tabular}{|c|c|c|c|c|c|c|}
\hline \multirow{2}{*}{ VARIÁVEL } & \multicolumn{2}{|c|}{ COMUNIDADE A } & \multicolumn{2}{|c|}{ COMUNIDADE B } & \multicolumn{2}{|c|}{ TOTAL } \\
\hline & $\mathbf{n}$ & $\%$ & $\mathbf{n}$ & $\%$ & $\mathbf{n}$ & $\%$ \\
\hline \multicolumn{7}{|l|}{ Faixa etária } \\
\hline 60 a 65 anos & 9 & 40,9 & 7 & 31,8 & 16 & 36,4 \\
\hline 66 a 70 anos & 13 & 59,1 & 15 & 68,2 & 28 & 63,6 \\
\hline \multicolumn{7}{|l|}{ Sexo } \\
\hline Masculino & 7 & 31,8 & 7 & 31,8 & 14 & 31,8 \\
\hline Feminino & 15 & 68,2 & 15 & 68,2 & 30 & 68,2 \\
\hline \multicolumn{7}{|l|}{ Estado civil } \\
\hline Solteiro & 1 & 4,5 & - & - & 1 & 2,3 \\
\hline Casado/União estável & 16 & 72,8 & 14 & 63,7 & 30 & 68,2 \\
\hline Separado/Divorciado & 2 & 9 & 6 & 27,3 & 8 & 18,2 \\
\hline Viúvo & 3 & 13,7 & 2 & 9 & 5 & 11,3 \\
\hline
\end{tabular}


(continuação)

\begin{tabular}{|c|c|c|c|c|c|c|}
\hline \multirow{2}{*}{ VARIÁVEL } & \multicolumn{2}{|c|}{ COMUNIDADE A } & \multicolumn{2}{|c|}{ COMUNIDADE B } & \multicolumn{2}{|c|}{ TOTAL } \\
\hline & $n$ & $\%$ & $n$ & $\%$ & $n$ & $\%$ \\
\hline \multicolumn{7}{|l|}{ Religião } \\
\hline Católica & 20 & 91 & 19 & 86,5 & 39 & 88,7 \\
\hline Evangélica & 1 & 4,5 & 1 & 4,5 & 2 & 4,5 \\
\hline Espírita & 1 & 4,5 & 1 & 4,5 & 2 & 4,5 \\
\hline Outras & - & - & 1 & 4,5 & 1 & 2,3 \\
\hline \multicolumn{7}{|l|}{ Escolaridade } \\
\hline 1 a 3 anos de estudo & 1 & 4,5 & 2 & 9 & 3 & 6,8 \\
\hline 4 a 7 anos de estudo & 1 & 4,5 & 4 & 18,2 & 5 & 11,3 \\
\hline Mais de 7 anos & 20 & 91 & 16 & 72,8 & 36 & 81,9 \\
\hline \multicolumn{7}{|l|}{ Moradia } \\
\hline Própria & 22 & 100 & 19 & 86,4 & 41 & 93,2 \\
\hline Alugada & - & - & 3 & 13,6 & 3 & 6,8 \\
\hline \multicolumn{7}{|l|}{ Dependentes da renda } \\
\hline Nenhuma & 5 & 22,7 & 10 & 45,5 & 15 & 34,1 \\
\hline 1 pessoa & 8 & 36,3 & 5 & 22,7 & 13 & 29,5 \\
\hline 2 a 4 pessoas & 9 & 41 & 7 & 31,8 & 16 & 36,4 \\
\hline \multicolumn{7}{|l|}{ Arranjo Familiar } \\
\hline Mora sozinho & 3 & 13,6 & 4 & 18,2 & 7 & 16 \\
\hline Com o esposo & 11 & 50 & 9 & 41 & 20 & 45,4 \\
\hline Com os filhos & 3 & 13,7 & 3 & 13,7 & 6 & 13,6 \\
\hline Com esposo mais filhos & 5 & 22,7 & 6 & 27,2 & 11 & 25 \\
\hline \multicolumn{7}{|c|}{ Participação em atividades sociais } \\
\hline $\operatorname{Sim}$ & 17 & 77,3 & 19 & 86,4 & 36 & 81,8 \\
\hline Não & 5 & 22,7 & 3 & 13,5 & 8 & 18,2 \\
\hline TOTAL & 22 & 100 & 22 & 100 & 44 & 100 \\
\hline
\end{tabular}

(conclusão)

Quanto a situação atual de trabalho, a maioria era aposentado $(77,3 \%)$. Entre os que continuavam em atividades laborais formais $(18,2 \%)$ as ocupações eram advogado, autônomo, bancário, contador, cuidador de idoso, funcionário público, microempresário e motorista (Tabela 06). 
De acordo com a Classificação Brasileira de Ocupações, os grupos mais predominantes foram os técnicos de nível médio $(52,3 \%)$ seguidos pelos trabalhadores de serviços administrativos (Tabela 06).

A maioria dos idosos autodeclararam sua capacidade para o trabalho como boa $(54,6 \%)$ e todos negaram faltas durante a vida laboral (Tabela 06).

Para $9,1 \%$ dos idosos da comunidade $A$ a sua capacidade para o trabalho era ruim enquanto que, na comunidade $B$ não encontramos nenhum idoso que assim o considerasse, sendo que $22,7 \%$ a consideravam ótima e $9,1 \%$ estavam inseridos em atividades laborais informais (síndicos) e voluntária (professores do Projeto Samuel Rangel). Na comunidade A encontramos $81,8 \%$ de aposentados em ambas as comunidades (Tabela 06).

Tabela 06 - Condição de trabalho e ocupação dos idosos jovens segundo localidade. São Paulo, 2019

\begin{tabular}{lcccccc}
\hline \multirow{2}{*}{ VARIÁVEL } & \multicolumn{2}{c}{ COMUNIDADE A } & COMUNIDADE B & \multicolumn{2}{c}{ TOTAL } \\
\cline { 2 - 7 } & $\mathbf{n}$ & $\%$ & $\mathbf{n}$ & $\mathbf{\%}$ & $\mathbf{n}$ & $\mathbf{\%}$ \\
\hline $\begin{array}{l}\text { Situação atual de trabalho } \\
\quad \text { Trabalho formal }\end{array}$ & 4 & 18,2 & 4 & 18,2 & 8 & 18,2 \\
$\quad \begin{array}{l}\text { Trabalho informal/voluntário } \\
\text { Aposentado }\end{array}$ & - & & 2 & 9,1 & 2 & 4,5 \\
Capacidade de trabalho autorreferida & 18 & 81,8 & 18 & 81,8 & 34 & 77,3 \\
$\quad$ Ótima & 3 & 13,6 & 5 & 22,7 & 8 & 18,2 \\
$\quad$ Boa & 12 & 54,6 & 12 & 54,6 & 24 & 54,6 \\
$\quad$ Moderada & 5 & 22,7 & 5 & 22,7 & 10 & 22,7 \\
$\quad$ Ruim & 2 & 9,1 & - & - & 2 & 4,5 \\
Faltas ao trabalho & & & & & & \\
$\quad$ Não & 22 & 100 & 22 & 100 & 44 & 100 \\
\hline TOTAL & $\mathbf{2 2}$ & $\mathbf{1 0 0}$ & $\mathbf{2 2}$ & $\mathbf{1 0 0}$ & $\mathbf{4 4}$ & $\mathbf{1 0 0}$ \\
\hline
\end{tabular}

${ }^{1}$ Os idosos que realizavam trabalho informal/voluntário já se encontravam aposentados.

Em relação às condições de saúde, $70,5 \%$ percebia sua saúde como boa ea maioria $(81,8 \%)$ não consumiam tabaco e $75 \%$ não faziam uso de bebidas alcóolicas, a mesma porcentagem tinham plano de saúde. Houve predomínio $(90,9 \%)$ dos que faziam uso diário de medicamentos, principalmente na comunidade B $(95,5 \%)$. 
Encontramos maior números daqueles que ingeriam de uma a duas drogas mas $31,8 \%$ faziam uso de mais de cinco medicamentos(Tabela 07).

Apesar da maioria ser aposentados $63,6 \%$ dos idosos adquiriam os medicamentos com seus próprios recursos, ainda que $36,4 \%$ dos idosos da comunidade B utilizavam recursos do Sistema Único de Saúde (SUS). Somente $13,6 \%$ dos idosos foram hospitalizados no último ano e $52,3 \%$ não realizaram tratamento odontológico(Tabela 07).

Tabela 07 - Condição de saúde de idosos jovens segundo localidade. São Paulo, 2019

\begin{tabular}{|c|c|c|c|c|c|c|}
\hline \multirow{2}{*}{ VARIÁVEL } & \multicolumn{2}{|c|}{ COMUNIDADE A } & \multicolumn{2}{|c|}{ COMUNIDADE B } & \multicolumn{2}{|c|}{ TOTAL } \\
\hline & $\mathbf{n}$ & $\%$ & $\mathbf{n}$ & $\%$ & $\mathbf{n}$ & $\%$ \\
\hline \multicolumn{7}{|l|}{ Autopercepção de saúde } \\
\hline Muito boa & 2 & 9,1 & 3 & 13,6 & 5 & 11,3 \\
\hline Boa & 14 & 63,6 & 17 & 77,3 & 31 & 70,5 \\
\hline Regular & 6 & 27,3 & 2 & 9,1 & 8 & 18,2 \\
\hline \multicolumn{7}{|l|}{ Consumo de tabaco } \\
\hline Sim & 3 & 13,6 & 5 & 22,7 & 8 & 18,2 \\
\hline Não & 19 & 86,4 & 17 & 77,3 & 36 & 81,8 \\
\hline \multicolumn{7}{|c|}{ Consumo de bebida alcoólica } \\
\hline Sim & 7 & 31,8 & 4 & 18,2 & 11 & 25 \\
\hline Não & 15 & 31,8 & 18 & 81,8 & 33 & 75 \\
\hline \multicolumn{7}{|l|}{ Plano de saúde } \\
\hline Sim & 18 & 81,8 & 15 & 31,8 & 33 & 75 \\
\hline Não & 4 & 18,2 & 7 & 31,8 & 11 & 25 \\
\hline \multicolumn{7}{|l|}{ Uso diário de medicamentos } \\
\hline Sim & 19 & 86,4 & 21 & 95,5 & 40 & 90,9 \\
\hline Não & 3 & 13,6 & 1 & 4,5 & 4 & 9,1 \\
\hline \multicolumn{7}{|l|}{ Quantidade diária ingerida } \\
\hline 1 a 2 medicamentos & 9 & 41 & 10 & 45,5 & 19 & 43,2 \\
\hline 3 a 4 medicamentos & 1 & 4,5 & 6 & 27,3 & 7 & 15,9 \\
\hline 5 a 6 medicamentos & 7 & 31,8 & 4 & 18,2 & 11 & 25 \\
\hline Mais de 6 medicamentos & 2 & 9,1 & 1 & 4,5 & 3 & 6,8 \\
\hline Não faz uso & 3 & 13,6 & 1 & 4,5 & 4 & 9,1 \\
\hline
\end{tabular}


(continuação)

\begin{tabular}{|c|c|c|c|c|c|c|}
\hline \multirow{2}{*}{ VARIÁVEL } & \multicolumn{2}{|c|}{ COMUNIDADE A } & \multicolumn{2}{|c|}{ COMUNIDADE B } & \multicolumn{2}{|c|}{ TOTAL } \\
\hline & $\mathbf{n}$ & $\%$ & $\mathbf{n}$ & $\%$ & $\mathbf{n}$ & $\%$ \\
\hline \multicolumn{7}{|l|}{ Aquisição dos medicamentos } \\
\hline Sistema Único de Saúde & 3 & 13,6 & 8 & 36,4 & 11 & 25 \\
\hline Doação de terceiros & 1 & 4,5 & - & - & 1 & 2,3 \\
\hline Compra com recurso próprio & 15 & 68,3 & 13 & 59,1 & 28 & 63,6 \\
\hline Não faz uso & 3 & 13,6 & 1 & 4,5 & 4 & 9,1 \\
\hline \multicolumn{7}{|c|}{ Internação hospitalar no último ano } \\
\hline Sim & 4 & 18,2 & 2 & 9,1 & 6 & 13,6 \\
\hline Não & 18 & 81,8 & 20 & 90,9 & 38 & 86,4 \\
\hline \multicolumn{7}{|c|}{ Tratamento odontológico no último ano } \\
\hline Sim & 12 & 54,5 & 9 & 40,9 & 21 & 47,7 \\
\hline Não & 10 & 45,5 & 13 & 59,1 & 23 & 52,3 \\
\hline \multicolumn{7}{|l|}{ Quedas no último ano } \\
\hline $\operatorname{Sim}$ & 4 & 18,2 & 8 & 36,4 & 12 & 27,3 \\
\hline Não & 18 & 81,8 & 14 & 63,6 & 32 & 72,7 \\
\hline TOTAL & 22 & 100 & 22 & 100 & 44 & 100 \\
\hline
\end{tabular}

(conclusão)

Quanto à queda, $72,73 \%$ informaram não ter caído no último ano, porém verificou-se entre as ocorrências de queda houve o dobro na Comunidade $B$, sendo que a maioria destas ocorreram durante o uso do transporte público.

\subsection{REPRESENTAÇÕES SOCIAIS SOBRE TRABALHO E APOSENTADORIA}

A análise dos dados, sustentada pelo marco teórico das Representações Sociais permitiu a reconstrução dos significados atribuídos pelos idosos jovens ao trabalho e aposentadoria, possibilitando uma apreensão abrangente da representação da realidade para esse grupo, considerando o contexto social e cultural em que estavam inseridos 
Por meio do referencial da Análise de Conteúdo e da TRS, os discursos foram examinados, conforme dito anteriormente, e a partir das categorias analítica trabalho e aposentadoria, emergiram duas categorias centrais: O idoso e o mercado de trabalho: entre a necessidade e a utilidade e $A$ vida após a aposentadoria: o descanso merecido e a necessidade de adaptação ao novo (Figura 02).

O Quadro 01 sumariza as categorias analíticas (trabalho e aposentadoria), categorias centrais, empíricas, subcategorias e as unidades de registro.

Quadro 01 - Processo analítico das entrevistas e as categorias segundo o Referencial Teórico. São Paulo, 2019

\begin{tabular}{|c|c|c|c|c|}
\hline $\begin{array}{l}\text { Referencial } \\
\text { teórico }\end{array}$ & $\begin{array}{l}\text { Categorias } \\
\text { analíticas }\end{array}$ & Categorias Centrais & $\begin{array}{l}\text { Categorias } \\
\text { empíricas }\end{array}$ & Subcategorias \\
\hline \multirow{5}{*}{ 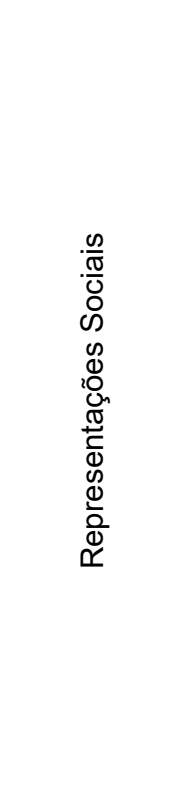 } & \multirow{3}{*}{ Trabalho } & \multirow{3}{*}{$\begin{array}{l}\text { O idoso e o mercado } \\
\text { de trabalho: entre a } \\
\text { necessidade e a utilidade }\end{array}$} & $\begin{array}{l}\text { Senso de } \\
\text { Utilidade }\end{array}$ & $\begin{array}{l}\text { Trabalho como meio de } \\
\text { inclusão social e } \\
\text { realização do idoso }\end{array}$ \\
\hline & & & $\begin{array}{l}\text { Satisfação das } \\
\text { necessidades }\end{array}$ & $\begin{array}{c}\text { Trabalho como meio de } \\
\text { sobrevivência e garantia } \\
\text { de sustento }\end{array}$ \\
\hline & & & $\begin{array}{l}\text { Dificuldades na } \\
\text { tomada de } \\
\text { decisão }\end{array}$ & $\begin{array}{c}\text { Condições que } \\
\text { influenciam o idoso na } \\
\text { decisão entre o trabalho e } \\
\text { a aposentadoria }\end{array}$ \\
\hline & \multirow{2}{*}{ Aposentadoria } & \multirow{2}{*}{$\begin{array}{c}\text { A vida após a } \\
\text { aposentadoria: o descanso } \\
\text { merecido e a necessidade } \\
\text { de adaptação ao novo }\end{array}$} & $\begin{array}{l}\text { Premiação pelo } \\
\text { tempo de } \\
\text { trabalho }\end{array}$ & $\begin{array}{c}\text { Aposentadoria como } \\
\text { direito garantido e } \\
\text { descanso no final do ciclo } \\
\text { laboral }\end{array}$ \\
\hline & & & $\begin{array}{c}\text { Adaptação à } \\
\text { nova rotina de } \\
\text { vida }\end{array}$ & $\begin{array}{c}\text { Tempo, falta da rotina e } \\
\text { atividades atuais após a } \\
\text { aposentadoria }\end{array}$ \\
\hline
\end{tabular}




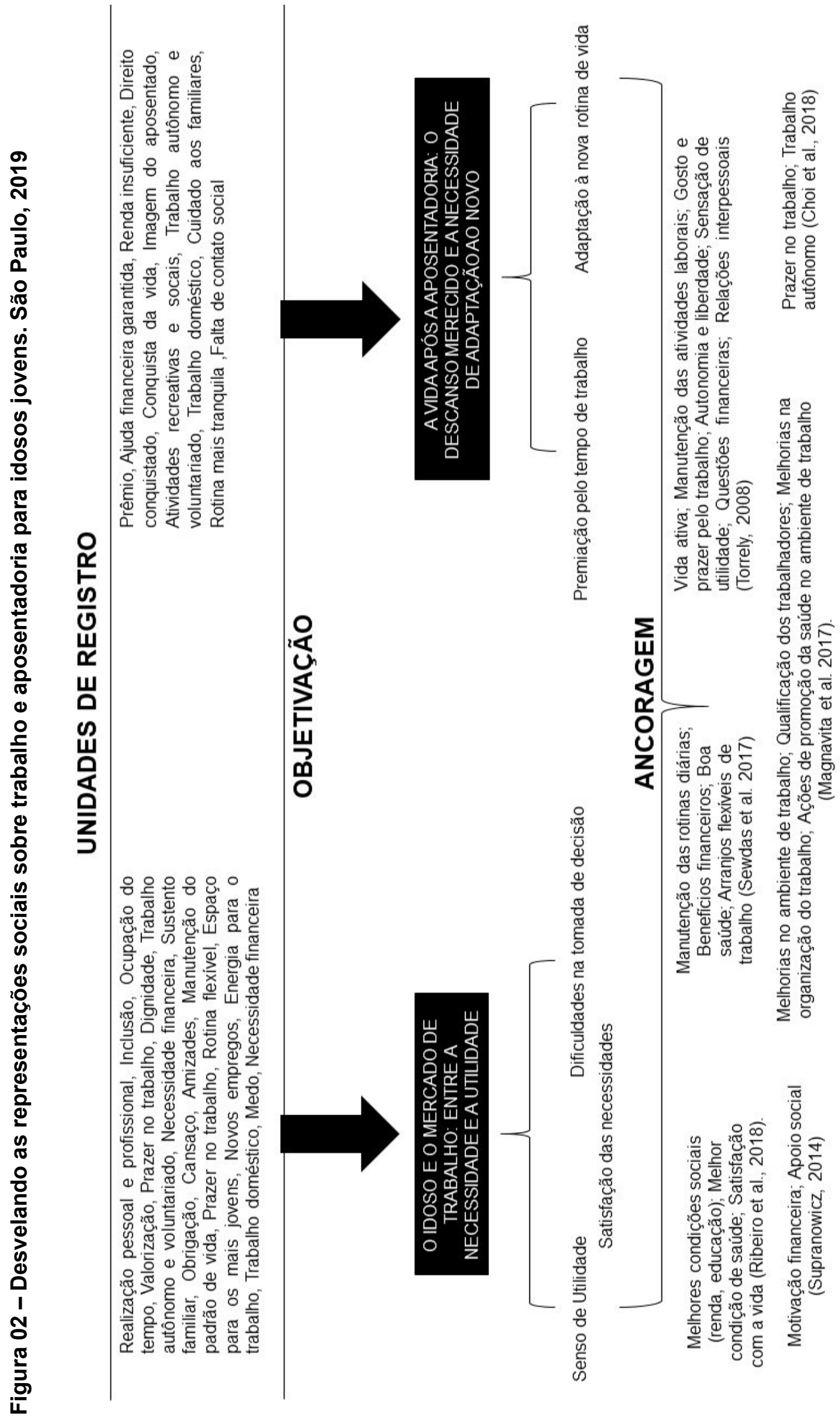




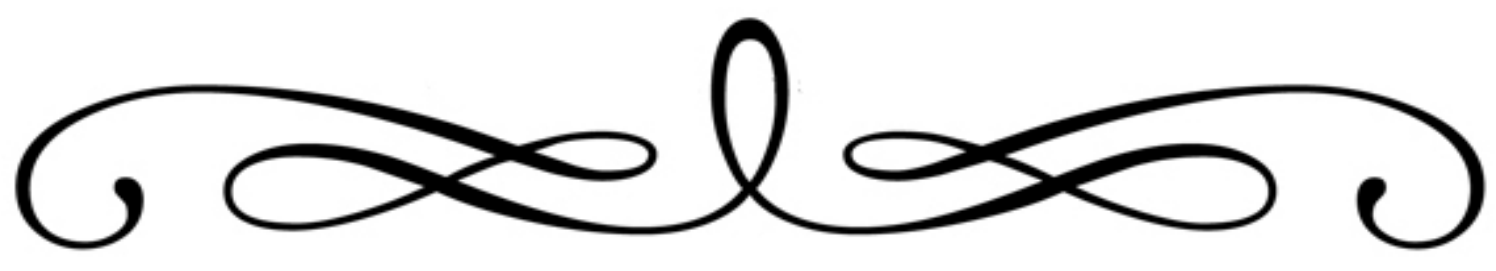

8 DISCUSSÃO

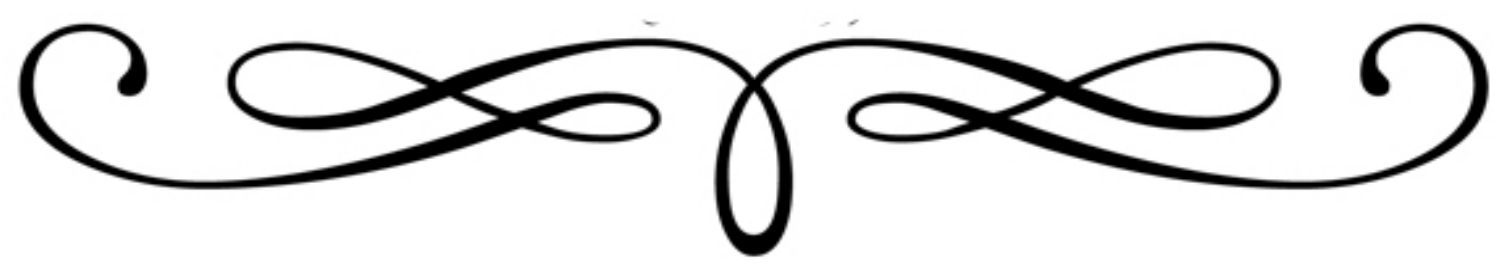




\section{DISCUSSÃO}

O envelhecimento populacional é uma realidade em todas as regiões do mundo e vem progredindo mais rapidamente nos países em desenvolvimento, sobretudo no Brasil, que ocupou o terceiro lugar entre os participantes do BRICS (Brasil, Rússia, Índia, China e África do Sul) com um índice de envelhecimento de 0,3 estando abaixo apenas da Rússia e da China (Nunes, Barreto e Gonçalves, 2012).

Os idosos se configuram um grupo geracional heterogêneo na qual é importante conhecer informações sobre os aspectos socioeconômicos, demográficos, condições de saúde e estilo de vida, que poderão nortear políticas públicas, programas e modelos de intervenção adequados para atender suas necessidades e seus interesses (Pagotto, Bachion, Silveira, 2013).

A sociedade contemporânea vem debatendo questões referentes à idade da população, uma vez que o número e a proporção de idosos vem aumentando progressivamente e de maneira mais rápida que em outras faixas etárias. A expectativa de vida nos países em desenvolvimento chegou a 68 anos no período entre 2010 e 2015 e espera-se que até 2050, possamos atingir 74 anos de vida (UNFPA, 2012).

Entre os idosos jovens participantes desse estudo, a idade média foi 66,2 anos ( $d p: 3.36)$, média de idade semelhante as encontradas em estudos realizados com com moradores da zona rural mineira (Garbaccio et al., 2017) e em outros países como China (Lee, Kim, 2017) e Cingapura (Schwingel et. al., 2009).

Com esse aumento da expectativa de vida, o número de idosos no mercado de trabalho também sofreu um acréscimo significativo nos últimos anos e, de acordo com as projeções para 2040, cerca de $57 \%$ da PIA terá idade superior a 45 anos (IPEA, 2010). Portanto, mais pessoas continuarão em suas atividades laborais considerando o rápido processo de envelhecimento da população, as dificuldades de pagamento das aposentadorias, a escassez de mão de obra especializada e de trabalhadores mais eficientes para garantir a sustentabilidade da economia do país (França et al., 2017).

No entanto, mais idosos no mercado de trabalho pode favorecer posturas discriminatórias, tanto por parte das pessoas em geral quanto do próprio contexto 
organazicional, uma vez que nossos julgamento sociais no cotidiano são, com frequência, baseados na idade (Goldani, 2010).

Assim emerge o termo ageísmo, concebido por Robert Butller e se relaciona com atitudes preconceituosas com idosos em relação à velhice incluindo a dos próprios idosos, bem como as práticas e políticas que discriminam o idoso no contexto laboral e em outras oportunidades de desenvolvimento dos papéis sociais, impedindo os mesmos de viver com dignifidade e satisfação (Butller, 1980).

Podendo ser denominado por preconceito de idade, o ageísmo é uma forma de estereotipar e discriminar pessoas idosas o que pode afetar decisões relacionadas à sua carreira, contratos empregatícios, cuidados médicos e políticas sociais (França et al., 2017).

No discurso dos idosos participantes deste estudo não houve menção de aspectos relacionados a esse tipo de preconceito, mesmo sendo um problema crescente na contemporaneidade. No entanto, apenas um deles referiu dificuldade de retornar ao mercado de trabalho por falta de oportunidades de emprego.

“... aqui é muito difícil e nem tem como para a gente com a nossa idade não surge um trabalho assim, mesmo que eu quisesse não tem como" (ID 12. Aposentado)

No contexto organizacional, o ageísmo se configura em um importante fator de exclusão dos idosos no mercado de trabalho podendo abranger barreiras no recrutamento, treinamento e desenvolvimento profissional e influenciar a demissão, sobretudo quando o corte de funcionários se faz necessário (Siqueira-Brito, França, Valentini, 2016), mesmo sendo direito garantido, previsto no Artigo $n^{\circ} 27$ do Estatuto do Idoso, a não discriminação ou fixação de limite máximo de idade para contratação ou concursos, exceto se a natureza do cargo exigir (Brasil, 2003).

Assim sendo, algumas organizações têm empregado uma ferramenta gerencial denominada Gestão da Idade que tem como finalidade a adoção de uma postura positiva frente ao envelhecimento, com o intuito de valorizar o trabalhador idoso e oferecer propostas para minimizar seus efeitos e reduzir as barreiras etárias (Cepelos, 2013).

De acordo com o Fundo de População das Nações Unidas (2012) as mulheres são a maioria entre as pessoas idosas no mundo, sendo que para cada 100 idosas há aproximadamente 84 homens. Segundo o IBGE (2011) as mulheres idosas 
representam cerca de $56 \%$ da população brasileira com 60 anos e mais e que apresentavam expectativa de vida em torno dos 77 anos, cerca de oito anos a mais que os homens.

Como vimos, grande parte dos participantes desse estudo era do sexo feminino $(68,2 \%)$ corroborando com outros estudos na qual havia a maior participação de mulheres idosas (Machón et al., 2016; Berlezi, 2016; Janini, Bessler, Vargas, 2015).

A tendência de aumento no número de mulheres idosas pode ser visualizada em todo o mundo (UNDESA, 2013; UNFPA, 2012) o que tem despertado os olhares da sociedade para o fenômeno denominado feminização da velhice.

De maneira geral, as mulheres vivenciam durante suas vidas as desigualdades originadas pela influência do Patriarcado, entre elas violência, discriminação, menores salários e a dupla jornada laboral (Nicodemo, Godoy, 2010).

No contexto de envelhecimento, além dessas desigualdades a discriminação pela idade, a renda insuficiente, $\mathrm{o}$ isolamento social e as diferentes desordens ocasionadas pela aposentadoria, viuvez, afastamento dos filhos e o cuidado aos familiares dependentes exercem forte influência em suas vidas o que as tornam mais vulneráveis à problemas de saúde física e mental (Lima, Bueno, 2009).

Há, no ambiente laboral, uma relevante diferença de gênero, uma vez que a participação de mulheres no mercado com trabalho remunerado extrapola suas qualificações e condição de saúde, envolvendo uma complexa articulação com as questões familiares, como por exemplo ser mãe e sua posição no seio familiar (Castro et al., 2018).

Essa relação com o mercado de trabalho, as relações familiares e interpessoais se traduzem em inúmeras tarefas a serem desenvolvidas no dia-a-dia e atribuem às mulheres a carga da dupla ou tripla jornada de trabalho, as quais podem ser causadoras de estresse emocional, sobrecarga física e psíquica (Costa, 2018).

Dessa forma, a maior expectativa de vida das mulheres pode não significar uma vida mais saudável, o que requer ampliação de políticas públicas de proteção social além da necessidade premente de encorajá-las a refletir sobre seus direitos e lutar por um mundo com menor desigualdade e mais dignidade (Nicodemo, Godoy, 2010; Lima, Bueno, 2009), considerando o impacto significativo da feminização da velhice nas relações de gênero na contemporaneidade (Fernandes, Soares, 2012).

Quanto ao estado civil, a maioria dos idosos jovens declararam que eram casados e residiam com seus companheiros ou com os filhos, esse perfil foi 
encontrado em estudos com idosos americanos (Gonzales, Nowell, 2017), nordestinos (Freire et al., 2015) e com trabalhadores petroquímicos no Irã (Mazloumi et al., 2012).

Há evidências de que a parceria entre casais pode ser benéfica no contexto do trabalho, favorecendo novas perspectivas e canais abertos de emprego entre os casais em que um dos cônjuges ainda encontra-se no ambiente laboral (Gonzales, Nowell, 2017; Zhanget al., 2011). Por outro lado, o estudo de Wind et al. (2014) mostrou que a influência do parceiro pode favorecer na decisão pela aposentadoria precoce.

No censo de 2010 foi demonstrado que $87,2 \%$ das famílias brasileiras eram compostas por duas ou mais pessoas que guardavam entre si um grau de parentesco e 12,1\% viviam sozinhas (IBGE, 2010), o que se aproxima dos resultados deste estudo, na qual a maioria dos participantes conviviam com seus companheiros e filhos, além de uma parcela considerável de idosos que declararam morar sozinhos.

A família pode ser considerada um dos principais eixos da sociedade, desempenhando papel central na economia do país além de ser fonte de proteção, solidariedade e a essência das redes sociais, indispensáveis para a sobrevivência (Rabelo, Neri, 2015, IBGE, 2010).

$\mathrm{Na}$ contemporaneidade, a família vem sendo o centro do debate político pois, com o envelhecimento populacional, já é possível observar a constituição de novos arranjos familiares denominados famílias intergeracionais (Aguiar, Menezes, Camargo, 2017).

Em meio a essas mudanças na estrutura familiar, o idoso passa a desempenhar novos papéis, o de provedor do lar que, até então, era realizado por outras pessoas da família em idade ativa. No Brasil, os rendimentos dos idosos, muitas vezes derivados de sua aposentadoria e pensões, tem sido identificada como a principal fonte de renda da família, especialmente dos mais jovens (Ribeiro et al., 2018; Santana, Lima, 2012; Aerosa, Bulla, 2010).

Essa imagem de provedor pode não ser benéfica para o idoso especialmente em relação aos gastos com os familiares que limitam, de certa forma, seu acesso a outras oportunidades sociais e de lazer, bem como, pode gerar insegurança em relação ao apoio às atividades cotidianas caso necessitem (Rabelo, Neri, 2015).

Além dos novos arranjos e papéis sociais, a questão do idoso provedor do lar auxilia na desconstrução da hierarquia masculina no contexto de manutenção 
financeira da família, uma vez que já se sabe que as mulheres serão o maior contingente de pessoas na sociedade e de maneira direta, passariam a assumir, cada vez mais, as despesas do grupo familiar (Küchemann, 2012).

Entre os determinantes sociais, o envolvimento religioso tem um papel significativo diante dos desafios da vida moderna e pode ampliar as condições do idoso para lidar com as perdas decorrentes do próprio envelhecer (Barricelli et al.,2012).

A religiosidade é um sistema organizado de crenças, práticas e rituais de adoração, doutrina e símbolos que nos conectam com algo ou algúem maior que o mundo físico. Por meio dessa conexão favorecem o bem-estar, a qualidade de vida, a redução de angústia e demais sintomas depressivos (Araújo et al., 2008; Duarte et al., 2008).

Entre os idosos participantes deste estudo, houve predominínio do catolicismo e, esse perfil religioso foi encontrado em outros estudos brasileiros (Santos et. al., 2013; Barricelli et al.,2012) sugerindo que mesmo diante do crescimento de novas práticas religiosas, a população brasileira ainda mantém a hegemonia da religião católica, mesmo diante da redução observada nas últimas décadas (IBGE, 2010).

As crenças religiosas estimulam a adoção de práticas mais saudáveis, conectando e favorecendo o idoso na compreensão de que ele faz parte de algo maior. Essa conexão, por sua vez, beneficia o enfrentamento das mazelas do envelhecer, atuando como mediador entre as aflições e sua a realidade (Santos et. al., 2013; Barricelli et al.,2012).

Os debates sobre o envelhecimento populacional indicam para a diversidade desse fenômeno, uma vez que cada indivíduo envelhece de maneira singular. Do mesmo modo, a saúde é algo que varia de acordo com as experiências individuais e as condições econômicas, sociais e culturais de cada idoso (Costa e Silva, Menandro, 2014).

Entre os idosos jovens participantes deste estudo, 70,5\% autodeclararam sua saúde como boa e $81,8 \%$ estavam inseridos em diferentes atividades sociais. Além disso, a maioria não consumia álcool, tabaco, não sofreram quedas ou houve necessidade de hospitalização no último ano, demostrando que os mesmos apresentavam um estilo de vida saudável, ainda que a maioria fizesse uso regular de um a dois medicamentos diários. 
A autopercepção positiva da saúde foi encontrada em diferentes estudos: no sul do Brasil a prevalência dessa percepção foi de 51,2\% (Confortin et al., 2015), enquanto que no estudo realizado em Campinas (Borin et al., 2012), 80,9\% dos idosos percebiam positivamente sua condição de saúde. Essas diferenças podem estar relacionadas no formato de pergunta realizada como, também, nas diferenças socioeconômicas e demográficas entre as regiões estudadas.

Podendo ser considerado um importante indicador do estado de saúde das pessoas idosas, a autopercepção de saúde vem sendo empregada rotineiramente por ser vista como uma prática segura e confiável para predizer a sobrevida e expressar diferentes aspectos da saúde física, cognitiva, e emocional dos mesmos. (Borges et al., 2014; Bussato et al., 2014).

No estudo de Confortin et al (2015) perceber melhor a saúde, estava associado ao consumo moderado de álcool, lazer, história negativa de queda no ultimo ano e os que não faziam uso de polifarmácia, condições semelhantes à encontradas em nossa população.

Nesse contexto, é importante ressaltar que o uso de álcool pode ser nocivo entre os idosos, independente da classificação do consumo, pois pode haver risco aumentado para piora do estado físico e mental, isolamento social e déficit cognitivo (Barbosa et al., 2018; Caputo et al. 2012). Porém, estudos indicam que quantidades moderadas de Resveratrol, substância natural presente em vinhos tintos, pode ter efeitos benéficos sobre a saúde dos indíviduos, especialmente a nível cardiovascular e renal (Albertoni, Schor, 2015; Penna, Hecktheuer, 2004).

Com relação à participação em atividades de lazer, Hagger-Johnson et al.(2017) afirmavam a necessidade de promover comportamentos e hábitios saudáveis a fim de apoiar as iniciativas de extensão da vida profissional entre os idosos. Além disso, a promoção da participação em organizações religiosas, grupos de amizade e reuniões familiares pode ajudar a preservar a função cognitiva dos idosos (Choi, et al 2016).

Estudo realizado no Reino Unido destacou, como fatores associados à prática de atividade física, maior disponibilidade de tempo, recurso financeiros, níveis de energia com pessoas na fase de transição trabalho-aposentadoria, indicando que aqueles que desenvolveram ocupações mais manuais ao longo da vida mostraram redução na prática de exercícios (McDonald et al., 2015).

Dentre os fatores que exercem influência na permanência de idosos no mercado de trabalho, as condições de saúde têm sido amplamente estudada e apontada como 
um dos principais determinantes para que isso ocorra (Mazzona, 2014; Caban Martinez et al., 2011), assim como a ampliação do grupo social.

Outro fator descrito como relevante é o nível de escolaridade, uma vez que idosos com maior escolaridade apresentam melhores condições de saúde e uma ocupação mais qualificada que Ihes possibilita melhor remuneração (Welmer et al., 2013; Goldman, Smith, 2011).

Como visto anteriormente, houve predominância entre os idosos jovens com mais de sete anos de estudo, resultado semelhante ao encontrado na pesquisa de Castro et al. (2015) na qual 50,2\% possuíam escolaridade igual ou superior a oito anos. No entanto, $70,2 \%$ dos idosos entre 60 e 69 anos no Brasil não apresentam escolaridade ou possuem o ensino fundamental incompleto (IBGE, 2010).

Essa realidade vem despertando iniciativas públicas e ações não governamentais cuja finalidade é a de oferecer alfabetização e educação continuada para adultos e idosos, dado o impacto da escolaridade na vida social, econômica e trabalhista (Pilger, Menon, Mathias, 2011).

Entre essas iniciativas, surge a Universidade Aberta para a Terceira Idade (UNATI) que busca, por meio de programas de educação formal ou informal, contribuir com melhorias na saúde física, mental e social dos idosos, além de reinserí-lo no panorama tecnológico e globalizado do cenário contemporâneo (Veras, Caldas, 2004).

Quanto a situação atual de trabalho e sua capacidade autorreferida para trabalhar, a maioria dos idosos jovens encontrava-se aposentada e 18,2\% estavam ativos nas atividades laborais, inclusive desempenhando trabalho voluntário. Ademais, percebiam sua capacidade para trabalhar como boa e segundo a Escala de Lawton apresentavam-se com a funcionalidade preservada.

No estudo desenvolvido por Ribeiro et al. (2018) 13,1\% dos idosos mantinham atividade remunerada e, entre trabalhadores americanos. com idade média de 59 anos, $82 \%$ deles realizavam trabalho assalariado (Choi et al., 2018).

Sendo assim, muitos idosos, aposentados ou não, continuam trabalhando por algum tipo de necessidade, seja ela financeira, psicológica ou social, essa opção, está diretamente ligada ao significado que cada um atribui ao trabalho (Marra et al., 2013).

Como visto anteriormente, as Representações Sociais auxiliaram o pesquisador a reconstriur os significados de trabalho e aposentadoria entre os idosos jovens moradores das duas comunidades, os quais foram agrupados em duas categorias 
centrais: $O$ idoso e o mercado de trabalho: entre a necessidade e a utilidade e $\boldsymbol{A}$ vida após a aposentadoria: o descanso merecido e a necessidade de adaptação ao novo.

Na categoria $O$ idoso e o mercado de trabalho: entre a necessidade e a utilidade foram agrupadas as questões relacionadas a necessidade do trabalho para manter a sobrevivência individual e familiar, bem como o senso de utilidade concedido aos idosos por ocasião do trabalho, o que nos auxilia a rever o envelhecimento para além do pejorativo, do incapaz e do improdutivo. Outra questão abarcada por esta categoria se relaciona com as dificuldades em optar pela permanência ou saída do ambiente laboral, muitas vezes influenciadas por mitos sobre o idoso e o processo de envelhecimento.

Para alguns idosos jovens, trabalho é um ato necessário que carrega consigo as questões financeiras como meio de sustento individual e familiar bem como o caminho para adquirir bens para sua sobrevivência.

\footnotetext{
"Essencial para você adquirir aquilo que você sonha, que necessita. Trabalhar para mim é necessidade" (ID 02 - Trabalhador formal).

Um meio de sustento. Pode ser também, fazer alguma coisa que você preencha seu tempo adequadamente e goste de fazer. Isso que significa trabalhar. Trabalhar é criar, criar alguma coisa satisfatória para vida, ganhar dinheiro e se sustentar" (IDSP 08 - Aposentada).
}

Os discursos dos idosos jovens apontam para o engajamento no trabalho diante da necessidade de se sustentar e adquirir bens que lhes são importantes, como mostrou um estudo com idosos suecos na qual rebatiam qualquer associação de velhice com passividade (Lundgren, Liliequist, Sjöstedt, 2018). Esse novo papel do idoso o favorece no sentido de relativizar a imagem de dependente e incapaz, tanto no seio familiar quanto na sociedade em geral.

Com as novas configurações familiares, vistas anteriormente, essa preocupação com a renda oriunda do trabalho torna-se indispensável e, nesse contexto, adiar a aposentadoria pode ser visto como uma estratégia de contrabalancear a renda individual e familiar (Kruse, 2010).

Já para outros, o trabalho significa um meio de valorização, prazer, realização pessoal, inclusão e participação social, expressos pelo senso de utilidade. 


\begin{abstract}
"Trabalho para mim é uma maneira que a gente tem de realizações, não só a parte financeira porque hoje em dia eu acho muito difícil uma pessoa não precisar trabalhar. E o trabalho é uma maneira da gente se sentir feliz, ter colegas, ver coisas novas, mostrar suas capacidades né? Então eu acho que o trabalho é fundamental na vida de qualquer pessoa" (ID 22 - Aposentada).

"Trabalhar é dignidade. Me traz um prazer imenso. Você ser útil sabe. Se eu pudesse resumir o trabalho em uma única palavra seria dignidade, prazer mesmo. Eu tenho maior prazer em levantar pela manhã e ir trabalhar" (IDSP 14 - Trabalhadora formal).

“... mas pelo fato de me sentir útil porque quando você não tem dinheiro, não é remunerado, não é tão importante. O mais importante é você se sentir útil, fazer algo que vai ajudar alguém, que beneficia outra pessoa ou você mesmo é que é o importante. É utilidade mesmo. Eu acho que essas que param, elas acham que aposentou acabou, que é um trapo velho que jogou fora que não tem mais serventia e se sentem inúteis. Eu jamais faria isso. Eu não ia conseguir. Eu acho triste as pessoas que botam o pijama e ficam em casa. Eu acho muito triste porque a vida é muito mais do isso. Eu não me identifico com essas pessoas" (IDSP 01 - Trabalhadora formal).
\end{abstract}

O trabalho traz diferentes benefícios que vão desde a promoção da auto-estima, a utilidade, os relacionamentos até a segurança financeira, tendo como um de seus determinantes o desejo de contribuir para a sociedade. A preocupação dos idosos jovens em fazer algo para os outros, demonstrado nos discursos, reflete essa contribuição social que pode ser expressa por meio de sua experiência profissional e pelas habilidades desenvolvidas ao longo da vida laboral (Nicholson, Mayho, 2017).

No contexto do envelhecimento saudável, promover a participação ativa e produtiva dos idosos no trabalho significa enfatizar o sentido positivo do envelhecimento, uma vez que já se conhece a proteção contra perdas funcionais e psicoemocionais que o trabalho pode conferir aos mesmos (Dantas et al., 2017; Amorin, Salla, Trelha, 2014; D'Orsi et al., 2011).

No Brasil, atualmente, o debate sobre idade vem ganhando espaço na mídia e entre as diversas classes sociais devido a proposta da reforma de Previdência Social (PS). Essa proposta de reforma, como vimos, prevê o aumento da idade para concessão da aposentadoria sob a alegação de construir um sistema igualitário e garantir a sustentabilidade dos regimes previdenciários com base em um déficit de mais de $\mathrm{R} \$ 260$ bilhões nas contas da PS. Ademais, muda as alíquotas de contribuição as quais passarão a se basear na cobrança do Imposto de Renda da Pessoa Fìsica (Brasil, 2019).

Porém, o chamado déficit na PS tem origem no não cumprimento das regras da Constituição Federal de 1988, na qual prevê em seu artigo 195 que o orçamento da 
Seguridade Social (Previdência Social, Assistência Social e Saúde) seja no formato clássico tripartite, ou seja, empresários, trabalhadores e governo como responsáveis pela integralização dos recursos. Como forma de cumprir sua parte no orçamento, o governo criou na mesma época, duas novas contribuições: a Contribuição Social para o Financiamento da Seguridade Social (Cofins) e a Contribuição Social sobre o Lucro Líquido das Empresas (CSLL) (Fagnani, 2016).

No entanto, a partir do final do Governo Sarney, em 1989, a determinação constitucional deixou de ser cumprida, na qual o governo se apropriou dessas novas contribuições deixando o orçamento da PS a cargo apenas dos trabalhadores e empresários. Essa medida inconstitucional vem sendo perpetuada desde então pelos governos de Fernando Henrique Cardoso, Luis Inácio Lula da Silva, Dilma Vana Rousseff dando origem ao chamado "rombo" financeiro da Previdência (Lourenço, Lacaz, Goulart, 2017).

De maneira conjunta à proposta de reformar a PS, foi aprovada em julho de 2017, a Lei n 13.467 que altera a Consolidação das Leis do Trabalho (CLT) a fim de adequar a legislação às novas relações laborais. No contexto dessa lei, prevalece a terceirização total do trabalho, o favorecimento de acordos negociados entre as partes em detrimento do que era, até sua promulgação, legislado e propicia maiores facilidades para a demissão dos funcionários (Brasil, 2017; Lourenço, Lacaz, Goulart, 2017).

A terceirização centraliza o poder nas grandes empresas, possibilita o acúmulo do capital e elimina o gasto empresarial com o pagamento dos direitos sociais e trabalhistas, restando aos funcionários baixos salários e redução de benefícios como a participação nos lucros e entre outros (Lourenço, 2015).

Assim, a maior insegurança no trabalho e na vida diante da situação atual e futura em relação aos direitos trabalhistas e previdenciários pode por em risco a saúde dos funcionários e ser encarada como um obstáculo, ainda não calculado, sobre o próprio financiamento da PS (Lourenço, Lacaz, Goulart, 2017).

As questões relacionadas à reforma da PS devem incluir aspectos relacionados à saúde dos trabalhadores pois ao se pensar na ampliação da idade e do tempo de contribuição para a concessão do benefício, deve-se prever investimentos nas condições de trabalho, na promoção da capacidade funcional e para o trabalho (Godinho, Ferreira, 2017; Akiyama, 2015) além de dar ouvidos às expectativas dos próprios idosos em relação a continuação no ambiente laboral. 
Como apontam os idosos deste estudo que se mostravam favoráveis a continuar no trabalho ou a retornar ao mercado, com a oportunidade de ter maior controle sobre sua rotina laboral.

\begin{abstract}
"Continuei primeiro pela vocação da profissão e segundo para manter um padrão de vida razoável e não deixar aquilo cair. Não é por comodidade, não é por fanatismo de dinheiro, é por questão da vida normal. Dessa forma que estou agora eu escolho para quem eu trabalho e na causa que eu trabalho. Então pretendo continuar muito tempo" (ID 02 - Trabalhador formal)

"Eu trabalhei muito e numa época que tinha menos condição que agora e a gente sofreu muito sabe. E hoje, sei lá, pela condição de hoje, poder cair e se machucar mais fácil eu não gostaria de trabalhar de manhã até a noite. Eu gostaria de uma coisa mais aberta, liberal que fala né. Mais flexível né?" (IDSP 02 - Aposentada).
\end{abstract}

No estudo de Virtanen et al. (2014) a oportunidade de controlar o tempo de trabalho foi considerado um fator significativo para promover a participação de idosos no mercado de trabalho, independente da presença de alguma patologia. Trabalhadores idosos que mantém maior controle do tempo e influência no trabalho estariam mais protegidos do estresse e consequentemente, apresentariam melhor autopercepção de saúde, função cognitiva e níveis de pressão arterial (Schimitz, 2016).

A despeito disso, promover o trabalho em tempo parcial pode não ser considerada uma ferramenta bem sucedida para prolongar a vida ativa e promover o envelhecimento saudável. Os formuladores de políticas, os sindicatos e os empregadores devem ser cuidadosos ao implementar esse tipo de estratégia, uma vez que podem de maneira não intencional, encurtar a vida profissional e reduzir as taxas de emprego para essa população (Hess, Bauknecht, Pink, 2018).

Nesse contexto, os esforços para promover a participação dos idosos no mercado de trabalho se concentram: na promoção da saúde dos trabalhadores com vistas a redução das perdas funcionais, laborativas e aparecimento de lesões decorrentes da atividade, a redução do ageísmo, o aprimoramento e desenvolvimento de suas habilidades, bem como melhorias no ambiente do trabalho e acesso ao serviço de saúde ocupacional (Nicholson, Mayho, 2017; Magnavita et al., 2017, Gonzales, Nowell, 2017) .

Assim, de acordo com Noone et al. (2018) o maior foco deve ser dado as melhorias nas condições de trabalho listadas acima e não só ao aumento da idade para a concessão da aposentadoria. 
O governo chinês vem empenhando esforços para a suspensão gradual da idade de aposentadoria num futuro próximo, para tanto, mantém investimentos na criação de ambientes de trabalho ao longo da vida, maximizando a produtividade e o bemestar dos idosos e valorizando, sobretudo, sua participação ativa na sociedade e sua auto-realização (Tang et al., 2018).

O enfoque da idade como parâmetro para o trabalho reforça os mitos de que o trabalhador idoso apresenta menor produtividade e prejudica a inserção de jovens no ambiente laboral. Isso pode ser observado no discurso de alguns idosos que participaram desse estudo:

“... eu acho que a pessoa que aposenta e volta para o mesmo lugar, tira o lugar do novo, que tem ideia nova, sangue novo para poder melhorar. Eu acho que quanto mais tempo a gente vai ficando, a gente apesar de ter outros cursos de atualização e tudo, a pessoa mais nova tem mais força. Eu entendo isso" (ID 09 - Aposentada).

"Eu acho egoísta porque tinha que dar lugar para o outro. Depois de certo tempo de idade eu acho que já fez o que tinha que fazer e tinha que dar o lugar para os mais novos" (ID 13 - Aposentada).

"Olha, é muito fácil você falar que as pessoas estão ocupando lugar de outro. Mas eu não sei exatamente qual o critério deles. Então é difícil ficar julgando" (IDSP 5 - Aposentada).

Como podemos perceber, para alguns participantes a permanência deles no mercado de trabalho poderia prejudicar os mais jovens a conquistar um emprego. Para outra idosa jovem, deve existir algum motivo pelo qual os idosos continuam inseridos no ambiente laboral e julgá-los torna-se uma tarefa complexa diante da necessidade de cada um.

Esse pensamento, na qual o idoso não pode continuar atuando em sua profissão fortalece aquela concepção de envelhecimento enraizada no seio social, na qual prevê que o idoso é sinônimo de incapacidade e invalidez.

Como observado, o retorno ou permanência do idoso no mercado laboral condicionado a um maior controle de sua jornada bem como a concepção de que eles atrapalham os jovens a conquistarem seus empregos contribui para a dificuldade de tomar a decisão entre aposentar ou continuar trabalhando.

Mesmo diante dos benefícios que o trabalho pode ocasionar em suas vidas, esse período de transição para a aposentadoria é considerado um ponto significativo para mudança no estilo de vida dos idosos (Baxter et al., 2016). Em um estudo realizado 
com idosos em Los Angeles (Blanco et al., 2017) mostrou que a ausência de poupança e de preparação para se retirar do mercado de trabalho estava relacionada à fatores comportamentais e culturais, entre eles experiências familiares, religiosidade e a negação do próprio envelhecer.

Portanto, esses idosos podem ser encorajados a continuar inseridos no mercado de trabalho, seja na ocupação que exerceram durante a vida ou iniciar uma nova carreira. Da mesma forma, eles podem optar pela aposentadoria, por estarem cansados dos anos de trabalho, por entenderem que é preciso dar espaço para os mais jovens bem como recuperar os planos deixados de lado durante a vida dedicada às atividades laborais.

Já a categoria $\boldsymbol{A}$ vida após a aposentadoria: o descanso merecido e a necessidade de adaptação ao novo destaca a premiação financeira alcançada por meio do cumprimento dos requisitos legais para a concessão desse benefício, se configurando a garantia de renda para o aposentado e, também, pelas as estratégias adotadas por alguns desses idosos para se adaptar a essa nova fase da vida.

A aposentadoria é uma etapa de transição e de reestruturação de valores marcada por incertezas, insegurança e frustrações geradas pela cultura capitalista que agrega àqueles que não podem desempenhar sua função produtiva, o signo da do descarte e da falta de utilidade. Envolve diferentes sentimentos pois, com o rompimento das relações de trabalho, alguns indíviduos podem apresentar comportamentos depressivos, isolar-se socialmente ou desenvolver/exacerbar alguma enfermidade. Já para outros, essa etapa do ciclo vital é marcada por liberdade, tempo para novas conquistas e desenvolvimento pessoal (Pazzim, Marin, 2016 Barbosa, Traesel, 2013), ou seja um premio.

"É um prêmio que a gente recebe, pagou a vida inteira e trabalhou a vida inteira, é um prêmio, uma gratificação que a gente merece descansar um pouco, cuidar mais da gente" (ID 10. Aposentada).

Aposentadoria é mais uma garantia que a pessoa tem para a vida né... para o resto da vida... você não tem que preocupar com o dia de amanhã... quem aposenta só pensa em manter a garantia de sobrevivência” (IDSP 15. Trabalhador formal).

Como vimos, a aposentadoria é vista pelos idosos jovens como um direito garantido que permite aos mesmos o descanso após os anos dedicados ao trabalho. 
Além disso, é a garantia de recursos financeiros para manter a sobrevivência até o final da vida.

A maior parte da renda dos idosos brasileiros é derivada de suas aposentadorias e pensões, sendo mais importante na faixa etária entre 60 e 64 anos. Para os idosos mais velhos há uma tendência de superestimar sua satisfação com os rendimentos a medida que subestimam suas dificuldades financeiras (Bento, Lebrão, 2013).

Apesar dos benefícios expedidos pela Previdência Social terem como função primordial, assegurar a renda daqueles que perderam sua capacidade laborativa, observa-se ao longo dos anos que esse rendimento é considerado uma parcela importante na renda familiar, caracterizando a transferência intrageracional e evidenciando o papel do idoso como provedor, visto anteriormente (Reis et al., 2015; Tavares et al., 2011).

Dessa forma, o prêmio pelos anos de trabalho que poderia ser utilizado para lazer ou outras necessidades do idoso, passa a dar melhores condições de vida às suas famílias, sobretudo naquelas de baixa renda (Reis et al., 2015).

Pode-se perceber o quanto é sólido o significado de descanso e prêmio associado a aposentadoria, no entanto, a outra face desse processo pode ser, para alguns idosos, marcada por dificuldades de adaptação à nova rotina de vida e a busca por outras atividades para preencher o tempo ocioso.

\footnotetext{
"Não, a gente sente saudade sim. Por exemplo, nos primeiros dias quando chegava a entrada da escola, o horário da entrada, a hora do intervalo, a saída eu ficava assim ... agora eles estão fazendo isso, agora eles estão fazendo aquilo. No começo a gente fica até meio depressiva, meio sentindo que esta de lado, que acabou tudo, mas depois com o tempo a gente vai envolvendo com outras coisas" (IDSP 20. Aposentada).
}

Hoje sou professora voluntária, dou aula de pintura em tecido e participo dos grupos de mosaico e aula de memória" (IDSP 04. Aposentada com trabalho voluntário).

"Vendo TV, crochê, leio, durmo, faço palavra cruzada, saio de vez em quando, fico na Internet mexendo no Facebook, aprendi agora o WhatsApp, cuido da cachorrinha" (ID 19. Aposentada).

Sabemos que estudos têm apontado para o risco de declínio cognitivo (Xue et al., 2018) com a aposentadoria, no entanto, cuidar de netos, do cônjuge e ajudar de maneira informal ou voluntária em alguma atividade pode estar associado a um risco reduzido desse declínio (Luo et al., 2018) e, como visto anteriormente, participar de 
atividades de lazer e diferentes grupos sociais promove saúde e previne perdas cognitivas dessa população.

O comportamento social dos idosos é um processo dinâmico e multifacetado, que pode assumir, ao longo da vida, diferentes trajetórias considerando sua subjetividade e contexto na qual está inserido (Pinto, Neri, 2017).

Alguns idosos jovens relataram que não sentiram falta da rotina de trabalho após a aposentadoria, pois se engajaram nas atividades domésticas e de cuidado de outros familiares:

\begin{abstract}
"Não, não senti falta nenhuma porque eu coloquei outras coisas no lugar. Eu comecei a me dedicar mais aos meus netos, comecei a virar aquela vó ativa, que leva pra lá, leva pra cá, fazendo sempre uma coisa ou outra. Eu nunca fui parada, sempre agitada" (IDSP 22. Aposentada).

"Eu não. Eu aposentei na hora certa. Eu também não senti falta. Tem muito serviço dentro de casa. Nós mulheres temos essa jornada dupla de trabalho" (IDSP 17. Aposentada).
\end{abstract}

$\mathrm{Na}$ socidade moderna, os indivíduos são incentivados a planejar suas vidas, carreiras e questões financeiras em prol de uma melhor qualidade de vida e bem-estar (Bressan et al., 2013). Nesse contexto, surge o planejamento da aposentadoria.

Planejar a aposentadoria tem sido apontado pela literatura como uma estratégia que possibilita prevenir problemas de saúde, favorece a habilidade de gerenciamento do tempo e amplia as expectativas futuras, envolvendo uma tomada de decisão em prol de comportamentos facilitadores para encarar essa nova fase do ciclo vital (Rafalski, Andrade, 2016; Wang, Shultz, 2010; Adams, Rau, 2011).

Apenas um idoso relatou ter realizado um planejamento para a sua aposentadoria, desenvolvendo as habildades para o cargo em seu substituto.

\footnotetext{
“...Eu fiz um planejamento, inclusive para minha substituição na empresa, fui preparando um funcionário antes. Eu avisei um ano e meio antes eu avisei que eu ia aposentar." (ID 06 - Aposentado)
}

Como podemos perceber, planejar essa transição entre trabalho e aposentadoria não faz parte da realidade dos idosos deste estudo. O estudo de Lui et al. (2018) mostrou que o baixo planejamento para a aposentadoria de enfermeiros chineses estaria ligado às questões trabalhistas, especialmente ao trabalho em equipe e ao desenvolvimento pessoal. Neste estudo o treinamento do novo funcionário promoveu o planejamento da aposentadoria. 
Fatores comportamentais e culturais, entre eles a negação da aposentadoria, a religiosidade, experiências familiares e uma possível perda de independência financeira, poderiam estar associados a falta desse tipo de preparação e, consequentemente tornam mais complexas as decisões que envolvem a transição entre manter-se ativo no trabalho ou aposentar-se (Choi et al., 2018; Blanco et al., 2017).

Um estudo realizado na Coreia mostrou que a preparação para aposentadoria tem relação com sintomas depressivos, onde os indivíduos que realizaram essa preparação apresentaram menores escores de depressão, sugerindo que essa conduta possa proporcionar uma melhor saúde mental aos idosos (Ju et al., 2017).

No contexto financeiro, para evitar esse descompasso de dívidas Van Rooij, Lusardi e Alessie (2011) sugerem um processo educativo com vistas a aumentar o acúmulo de riqueza dos aposentados para garantir o bem-estar e evitar que os mesmos se tornem dependentes, exclusivamente, do apoio público.

Quando não planejada, a aposentadoria pode gerar mazelas no indivíduo que vão desde o aparecimento/agravamento de problemas físicos, psicológicos até financeiros, sobretudo o endividamento (Leandro-França et al. 2014).

Portanto, preparar para a aposentadoria é preparar o próprio envelhecimento, é propiciar oportunidades do sujeito refletir sobre sua vida e suas escolhas para encarar essa nova fase da vida (Barbosa, Traesel, 2013).

Os resultados encontrados nos permitem dizer que mesmo com boa saúde e capacidade para o trabalho auto percebidas, a decisão entre aposentar e continuar trabalhando está relacionada à forma como cada idoso compreende trabalho e aposentadoria. 


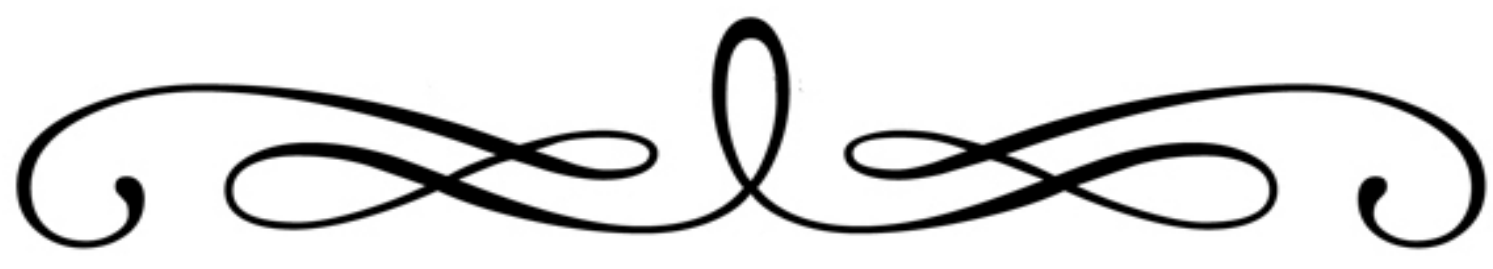

9 CONCLUSÃO

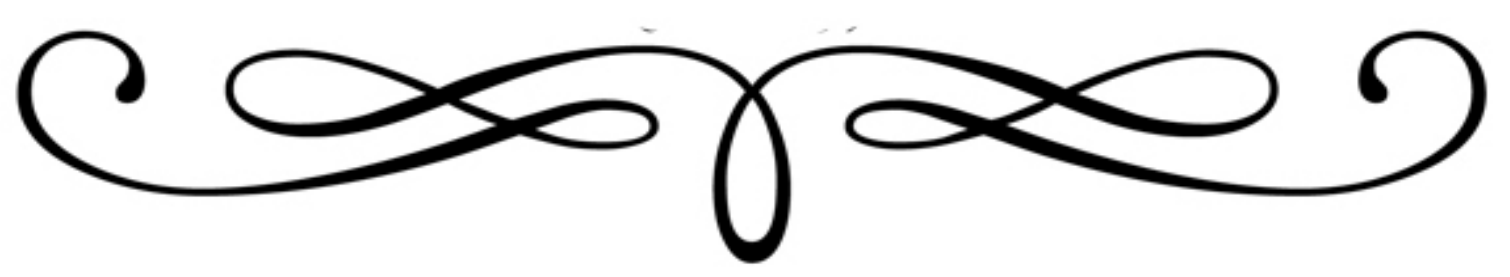




\section{CONCLUSÃO}

Este estudo nos possibilitou identificar e analisar os significados de trabalho e aposentadoria para idosos entre 60 e 70 anos, denominados idosos jovens, além de conhecer o perfil socioeconômico e suas condições de trabalho e saúde.

Quanto ao perfil socioeconômico e as condições de trabalho e saúde dos participantes encontrou-se uma população com funcionalidade, cognição e humor preservados, majoritariamente feminina, com boa autopercepção de saúde e de capacidade para o trabalho. Além disso, eram idosos com hábitos de vida saudáveis, que participavam de diferentes atividades sociais e de lazer.

Vale ressaltar que os idosos da comunidade $A$ eram mais jovens, com maior nível de escolaridade e todos possuíam a casa própria enquanto que, na comunidade $B$, eles participavam mais de atividades sociais, eram mais velhos e a maioria não declarou dependentes da renda.

Mesmo diante dessas diferenças, houve convergências nos discursos e consequentemente nos significados atribuídos a trabalho e aposentadoria, o que nos leva a refletir sobre a influência das condições econômicas, culturais e sociais no contexto do mercado de trabalho.

O trabalho foi associado a necessidade e ao senso de utilidade individual e coletivo. A tomada de decisão entre permanecer ativo no trabalho é percebida como dificuldade, uma vez que expressam o desejo de continuar trabalhando em rotinas mais flexíveis, independente da comunidade onde residiam.

A aposentadoria foi vista como descanso merecido e prêmio por terem atingido os requisitos necessários para sua concessão. Esse período de mudanças favoreceu a subjetividade dos idosos quanto as estrategias adotadas para se adaptar à nova rotina de vida. 


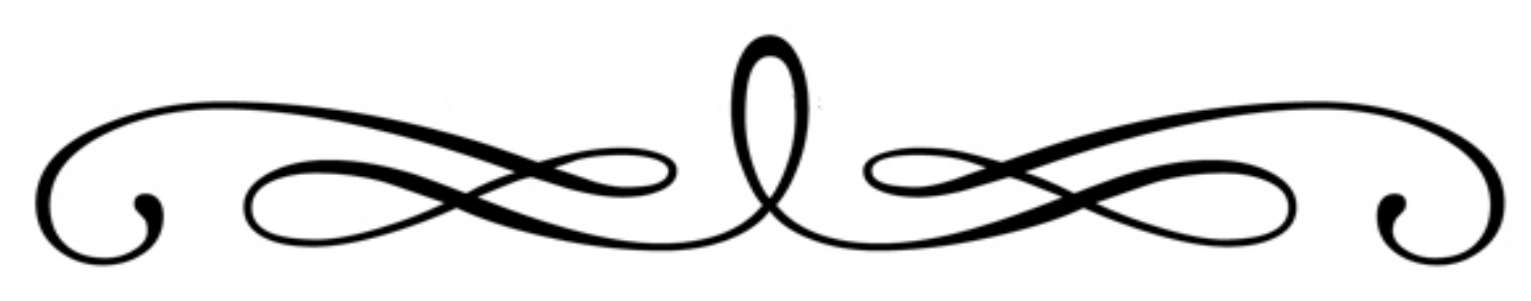

10 CONSIDERAÇÕES FINAIS

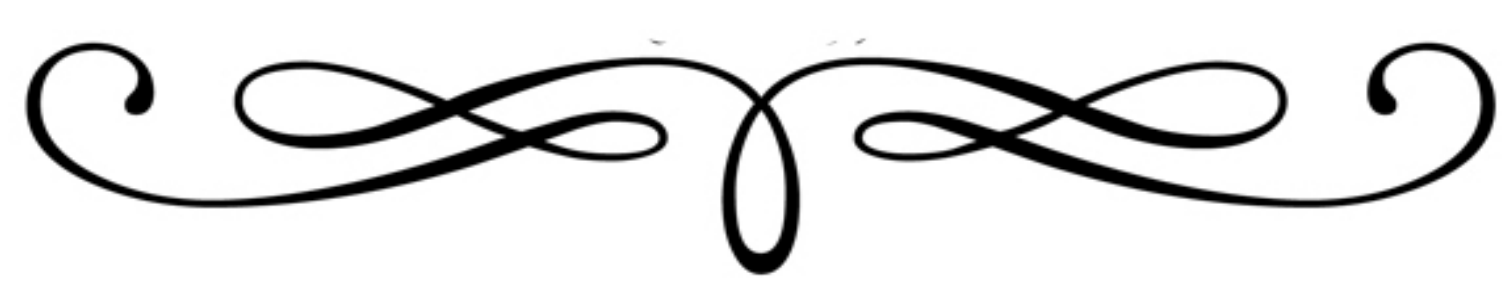




\section{CONSIDERAÇÕES FINAIS}

A análise dos dados mediada pelas RS possibilitou explorar a temática de trabalho e aposentadoria na visão de idosos jovens de duas comunidades e contribuir para ampliar o debate sobre o tema no momento em que a sociedade brasileira se encontra diante de dilemas que podem alterar as atuais configurações trabalhistas e previdenciárias.

Para alguns idosos, o trabalho era visto como um período de realizações e, com a aposentadoria, a rotina de trabalho foi dando espaço para outras atividades, sobretudo às domésticas e de cuidado familiar.

A sensação de utilidade, a vocação, o prazer pelo trabalho e a manutenção do padrão de vida são a mola propulsora que os mantém no mercado laboral e lhes dão a oportunidade de desmitificar a noção de envelhecer de pijamas.

Em meio a uma sociedade capitalista, ter idosos com essa representação de trabalho oportuniza uma mudança de paradigma, na qual trabalhar vai muito além das questões financeiras. Reforça o envelhecimento no sentido positivo e auxilia no desmonte do imaginário social que, mesmo diante de um franco processo de envelhecimento, ainda se esbarra na concepção de inatividade e inutilidade atribuída aos idosos.

Eles percebem a aposentadoria como um momento de descanso após a vida dedicada ao trabalho e tem, expresso pela noção de "prêmio", a segurança financeira para sustento individual e familiar. Nenhum idoso mostrou preocupação com as questões da reforma previdenciária proposta pelo atual governo.

Em uma população predominantemente feminina, esses achados reforçam a dupla ou tripla carga de trabalho das mulheres e nos chama a atenção para a importância de debater questões de gênero no envelhecimento e divulgar esse debate para toda sociedade com vistas a garantir o cumprimento das leis e melhorar as condições de vida dessa população.

No imaginário desses idosos, encontramos que sua permanência nas atividades laborais diminuí as possibilidades dos jovens entrarem para força de trabalho. Esse pensamento está ligado à questão tradicional da velhice e demonstra que a imagem 
negativa do envelhecimento pode influenciar nessa decisão de manter-se no trabalho ou se aposentar.

Com relação ao ageísmo, nenhum idoso relatou ter passado por esse tipo de ato preconceituoso ao longo de suas carreiras, ainda que um deles tenha expressado dificuldades para conseguir um novo emprego por conta da idade.

Com o aumento de idosos no mercado de trabalho, o ageísmo pode se configurar como um grande desafio para a gestão de pessoas, as organizações e sociedade como um todo. Atribuir a idade cronológica o determinante da capacidade laborativa é agir de maneira preconceituosa com os idosos e o desqualifica, uma vez que não considera as habilidades e atitudes desenvolvidas ao longo do trabalho.

As dificuldades na tomada de decisão entre aposentar e continuar trabalhando bem como as estratégias adotadas para a adaptação a nova rotina promovem a subjetividade do idoso e se relacionam diretamente com os significados atribuídos à temática.

Dar voz aos idosos é promover seu protagonismo social e um passo importante para garantir que as políticas públicas atendam as necessidades dos mesmos. No contexto de trabalho e da aposentadoria, ouví-los pode auxiliar as Organizações no enfrentamento dessas dificuldades sentidas durante a transição e promover melhor preparo para essa nova fase do ciclo vital.

Durante a coleta de dados, alguns idosos não aceitaram participar da entrevista após serem informados sobre a temática do estudo e justificaram a negativa pelo medo de que as respostas poderiam interferir no recebimento dos proventos da aposentadoria.

Outros idosos, ficaram empolgados e se sentiram felizes em poder compartilhar a história de sua vida laboral e experiências de vida, mostrando-se preocupados em atender adequadamente as perguntas, num clima de entusiasmo e expectativas.

Espera-se que os resultados aqui apresentados possam colaborar com os profissionais de saúde, especialmente os enfermeiros, a ampliar suas visões e nortear programas e ações para promover saúde e bem-estar, adoção de hábito saudável de vida, atividade física, social e de lazer, bem como prepará-los para a nova fase do ciclo vital.

Vale ressaltar, a preemente necessidade de investimentos em estratégias que garantam melhores condições e participação dos idosos no mercado de trabalho de acordo com sua vontade, livres de preconceito e exercendo sua dignidade e direitos. 


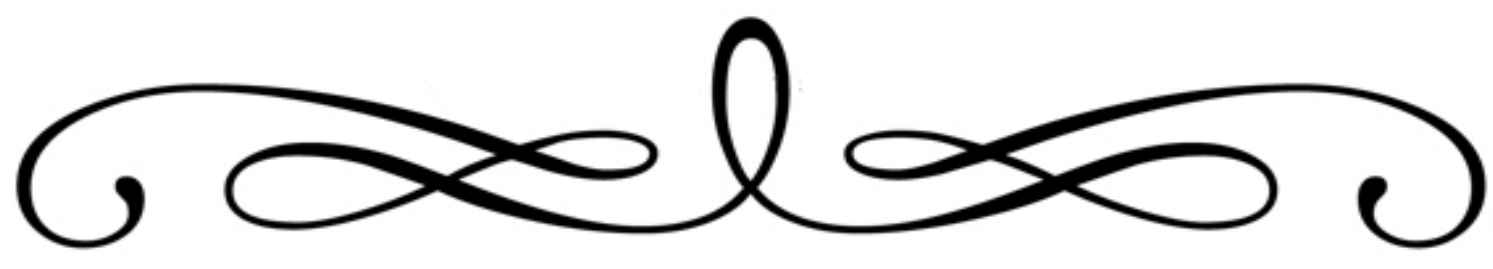

REFERÊNCIAS

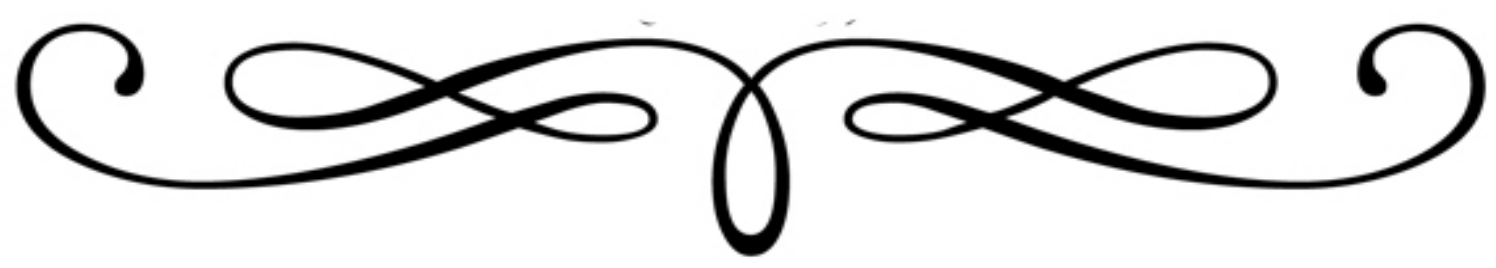




\section{REFERÊNCIAS}

Albornoz, S. O que é trabalho. 3 ed. Coleção Primeiros Passos. Editora Brasiliense, 1994.

Alvarenga LN, Kiyan L, Bitencourt B, Wanderley KS. Repercussões da aposentadoria na qualidade de vida do idoso. Rev. esc. enferm. USP [Internet].2009 [citado 2019 Abril. 23];43(4): 796-802. Disponível em: http://www.scielo.br/scielo.php?script=sci arttext\&pid= S0080-62342009000400009. DOI: 10.1590/S0080-62342009000400009.

Alves JED, Vasconcelos DS, Carvalho AA. Estrutura etária, bônus demográfico e população economicamente ativa no Brasil: cenários de longo prazo e suas implicações para o mercado de trabalho [citado 2019 Abril. 23]. Brasília: IPEA, 2010. (Textos para Discussão CEPAL-IPEA, 10). Disponível em: http://www.ipea.gov.br/portal/index.php?option=com content\&view= article\&id=9683.

Amorim J S, Salla S, Trelha CS. Factors associated with work ability in the elderly: Systematic review. Rev. bras. epidemiol. [Internet] 2014 [citado 2019 Abril. 23];17(4): 830-841. Available from: $\quad$ http://www.scielo.br/scielo.php?script=sci arttext\&pid=S1415-790X2014000400830. DOI: $10.1590 / 1809-4503201400040003$.

Araújo SA, Fontes BC, Carvalho MDS, Nascimento JMMF. Gênero, geração e trabalho: modos de vida de idosos/as residents em zona rural. RBCEH [Internet]. 2013 [citado 2019 Abril. 23]; 10(1): 66-78. Disponível em: http://seer.upf.br/index.php/rbceh/article/view/2977. DOI: 10.5335/rbceh.2012.2977.

Araya-Umaña, S. Las representaciones sociales: ejes teóricos para su discusión. Cuad Cienc Sociales [Internet]. 2002 [citado 2019 Abril. 23]; Cuaderno de Ciencias Sociales 127.

Arruda A. Teoria das representações sociais e teorias de gênero. Cadernos de Pesquisa [Internet]. 2002 [citado 2019 Abril. 23]; (117):127-147. Disponível em: http://www.scielo.br/scielo.php?script=sci arttext\&pid=S0100-

$15742002000300007 \&$ Ing $=e n \& n r m=i s o \& t$ lng=pt. DOI: $10.1590 / S 0100-15742002000300007$.

Azevedo DM, Miranda FAN. Teoria das representações sociais e ALCESTE: contribuições teórico-metodológicas na pesquisa qualitativa. Sau. \& Transf. Soc. [Internet]. 2012 [citado 2019 Abril. 23];3(4). Available from: http://www.redalyc.org/pdf/2653/265324588003.pdf.

Bardin L. Análise de Conteúdo. São Paulo. Edições 70; 2011. 279p.

Baxter S, Johnson M, Payne N, Bucley-Woods H, Blank L, Hock E et al. Promoting and maintaining physical activity in the transition to retirement: a systematic review of interventions for adults around retirement age. Int $J$ Behav Nutr Phys Act. 2016; 13: 12. DOI:10.1186/s12966-016-0336-3. 
Bernard HR. Research methods in anthropology: Qualitative and quantitative approaches. 3rd Alta Mira Press; Walnut Creek, CA: 2002.

Bolfarine $\mathrm{H}$, Bussab WO. Elementos de amostragem. Instituto de Matemática e Estatística [citado 2019 Abril. 23]. Universidade de São Paulo; 2004. Disponível em: ftp://est.ufmg.br/pub/denise/2016/Amostragem/Elementos\%20de\%20Amostragem\%20$\% 20$ Heleno\%20Bolfarine, $\% 20$ Wilton $\% 20$ Oliveira\%20Bussab.pdf.

Brasil. Câmara dos Deputados. Centro de Estudos e Debates Estratégicos Brasil 2050: desafios de uma nação que envelhece. Brasília: Edições Câmara, 2017.

Brasil. Conselho Nacional de Saúde. Ministério da Saúde. Resolução $n^{\circ} 466$, de 12 de dezembro de 2012 [citado 2019 Abril. 23]. Disponível em: http://bvsms.saude.gov.br/bvs/saudelegis/cns/2013/res0466 $12 \quad 12$ 2012.html.

Brasil. Ministério da Saúde. Envelhecimento e saúde da pessoa idosa [citado 2019 Abril. 23]. Brasília: Ministério da Saúde, 2007. Disponível em: http://bvsms.saude.gov.br/bvs/publicacoes/abcad19.pdf.

Brasil. Ministério da Saúde. Estatuto do idoso. 2 ed. Brasília: Editora do Ministério da Saúde, 2006a.

Brasil. Ministério da Saúde. Portaria $\mathrm{n}^{\circ} 2.528$ de 19 de outubro de 2006. Aprova a Política Nacional de Saúde da Pessoa Idosa [citado 2019 Abril. 23]. Disponível em: http://www.saudeidoso.icict.fiocruz.br/pdf/PoliticaNacionaldeSaudedaPessoaldosa.pdf.

Brito FC, Litovic J. Envelhecimento: prevenção e promoção da saúde. São Paulo: Atheneu; 2004. Conceitos Básicos; 226 p.

Brucki SMD, Nitrini R, Caramelli P, Bertolocci PHF, Okamoto IH. Sugestões para o uso do Mini-exame do estado mental no Brasil. Arq Neuro-Psiquiatr [Internet]. 2003 [citado 2019 Abril. 23];61(3):777-781. Disponível em: $\quad$ http://www.scielo.br/scielo.php?script=sci arttext\&pid=S0004-282X2003000500014\&lng=en\&nrm=iso\&tIng=pt. $\quad$ DOI: $\quad 10.1590 / S 0004-$ $282 \times 2003000500014$.

Bulla LC, Kaefer CO. Trabalho e aposentadoria: as repercussões sociais na vida do idoso aposentado. Revista Virtual Textos \& Contextos [Internet]. 2003 [citado 2019 Abril. 23]; 2(1):18. Disponível em: http://revistaseletronicas.pucrs.br/ojs/index.php/fass/article/view/957/737.

Caldas CP. Preparação para uma aposentadoria ativa. In: Barros Júnior JC (organizador.). Empreendedorismo, Trabalho e Qualidade de Vida na Terceira Idade. São Paulo: Editora Edicon; 2009. p. 141.

Camarano AA. The new demographic paradigm. Ciênc. saúde coletiva [Internet]. 2013 [cited 2019 Apr 23]; 18(12):3446. DOI: 10.1590/S1413-81232013001200001. 
Camarano AM. O idoso brasileiro no mercado de trabalho [citado 2019 Abril. 23]. Rio de Janeiro: IPEA, p. 1-27, 2001. (Texto para Discussão n.830). Disponível em: http://www.ipea.gov.br/agencia/images/stories/PDFs/TDs/td 0830.pdf.

Carmo PS. A ideologia do trabalho. São Paulo: Editora Moderna, 1992.

Ciosak SI, Braz E, Costa MFBNA, Nakano NGR, Rodrigues J, Alencar RA et al . Senescence and senility: the new paradigm in primary health care. Rev. esc. enferm. USP [Internet]. 2011 [cited 2019 Apr 23]; 45(spe2): 1763-1768. DOI: 10.1590/S0080-62342011000800022.

Cresswell JW, Plano Clark VL. Designing and conducting mixed method research. 2nd Sage; Thousand Oaks, CA: 2011.

d'Orsi E, Xavier AJ, Ramos LR. Work, social support and leisure protect the elderly from functional loss: EPIDOSO study. Rev. Saúde Pública [Internet] 2011 [citado 2019 Abril. 23];45(4):685-692. Available from: http://www.scielo.br/scielo.php?pid=S003489102011000400007\&script=sci arttext\&tlng=en.. DOI: 10.1590/S0034-89102011000400007.

Dantas RG, Perracini MR, Guerra RO, Eduardo F, Dias RC, Padula RS. What are the sociodemographic and health determinants for older adults continue to participate in work? Archives of Gerontology and Geriatrics [Internet]. 2017 [citado 2019 Abril. 23]. 71:136-141. Available from: http://www.sciencedirect.com/science/article/pii/S0167494317302121. DOI: 10.1016/j.archger.2017.04.005.

Duan N, Bhaumik DK, Palinkas LA, Hoagwood K. Optimal Design and Purposeful Sampling: Complementary Methodologies for Implementation Research. Adm Policy Ment Health [Internet]. 2015 [citado 2019 Abril. 23];42(5):524-532. DOI: 10.1007/s10488-014-0596-7.

Duarte SJH, Mamede MV, Andrade SMO. Opções teórico-metodológicas em pesquisas qualitativas: representações sociais e discurso do sujeito coletivo. Saude soc. [Internet]. 2009 [citado 2019 Abril. 23];18(4):620-626. Disponível em: http://www.scielo.br/scielo.php?script=sci arttext\&pid=S0104-12902009000400006. DOI: 10.1590/S0104-12902009000400006.

Duval R. The Retirement Effects of Old-Age Pension and Early Retirement Schemes in OECD Countries [citado 2019 Abril. 23]. OECD Economics Department Working Papers, n. 370, OECD Publishing, 2003. Available from: http://www.oecdilibrary.org/docserver/download/308728704511.pdf?expires=1495805040\&id=id\&accname=g uest\&checksum=71819DD9DEBCA3C26D9A87637E178CDA. DOI: 10.1787/308728704511.

Elder S. Sampling methodology: module 3. [citado 2019 Abril. 23]. International Labour Organization. Available from: http://www.ilo.org/wcmsp5/groups/public/@ed emp/documents/ instructionalmaterial/wcms 140859.pdf. 
European Commission. Directorate-General for Economic and Financial Affairs. The 2015 Ageing Report: Economic and budgetary projections for the 28 EU Member States (20132060) [citado 2019 Abril. 23]. European Economy, 2015. Available from: http://ec.europa.eu/economy finance/publications/european economy/2015/pdf/ee3 en.pdf.

Félix J. O idoso no mercado de trabalho. In: Alcântara AO, Camarano AA, Giacomin KC. Política nacional do idoso: velhas e novas questões. Rio de Janeiro: Ipea, 2016. $615 p$

Fernandes NG, Zordan MS. Relações entre trabalho, saúde e aposentadoria da pessoa idosa: uma abordagem teórica. Revista Científica da Faculdade de Balsas. [Internet]. 2012 [citado 2019 Abril. 23];3(3):1-10. Disponível em: http://www.unibalsas.edu.br/revista/index.php/unibalsas/article/view/43.

Ferreira OGL, Maciel SC, Silva AO, Sá RC, Moreira MASP. Significados atribuídos ao envelhecimento: idoso, velho e idoso ativo. Psico-USF, [Internet]. 2010 [cited 2019 Apr 23]; 15(3), 357-364. DOI: 10.1590/S1413-82712010000300009.

Foguel FHS, Normanha Filho MA. Reinserção do trabalhador idoso no mercado de trabalho: cluster é uma alternativa? Revista Gerenciais [Internet] 2006 [citado 2019 Abril. 23]; 5(2):6370. Disponível em: http://www.spell.org.br/documentos/ver/26884/reinsercao-do-trabalhadoridoso-no-mercado-de-trabalho--cluster-e-uma-alternativa.

Folstein MF, Folstein SE, McHugh PR. "Mini-mental state": A pratical method for grading the cognitive state of patients for the clinician. Journal of Psychiatric Research [Internet]. 1975 [citado 2019 Abril. 23];12(3):189-198. Available from: http://www.sciencedirect.com/science/article/pii/0022395675900266. DOI: $\quad$ 10.1016/00223956(75)90026-6.

Foster L, Walker A. Active and Successful Aging: A European Policy Perspective. Gerontologist. 2015; 55(1): 83-90. DOI: 10.1093/geront/gnu028

França CL, Murta SH, Negreiros JL, Pedralho M, Carvalhedo R. Intervenção Breve na Preparação para Aposentadoria. Rev. bras. orientac. Prof [Internet]. 2013 [citado 2019 Abril. 23];14(1):99-110. Disponível em: http://pepsic.bvsalud.org/scielo.php?script=sci arttext\&pid= S1679-33902013000100010.

França LHFP, Soares DHP. Preparação para a aposentadoria como parte da educação ao longo da vida. Psicol. cienc. Prof [Internet] 2009 [citado 2019 Abril. 23];29(4):738-751. Disponível em: $\quad$ http://www.scielo.br/scielo.php?script=sci arttext\&pid=S141498932009000400007. DOI: 10.1590/S1414-98932009000400007.

Giatti L, Barreto SM. Saúde, trabalho e envelhecimento. Cad. Saúde Pública [Internet] 2003 [citado 2019 Abri. 23];19(3): 759-771. DOI: 10.1590/S0102-311X2003000300008

Gonzales, E., \& Nowell, W. B. (2017). Social Capital and Unretirement: Exploring the Bonding, Bridging, and Linking Aspects of Social Relationships. Research on Aging, 39(10), 1100-1117. 
Haan P, Prowse V. Longevity, life-cycle behavior and pension reform. Journal of Econometrics. 2014 [citado 2019 Abril. 23];178(3):582-604. Available from: http://www.sciencedirect.com/ science/article/pii/S0304407613002042. DOI: 10.1016/j.jeconom.2013.08.038.

Hayutin A, Beals M, Borges The aging US workforce: a chatbook of demographic shifts [citado 2019 Abril. 23]. Stanford Center on Longevity, 2013. Available from: http://longevity3.stanford.edu/wp-content/uploads/2014/01/The Aging U.S.-Workforce.pdf.

Heijdra BJ, Romp WE. Retirement, pensions and ageing. Journal of Public Economics [Internet]. 2009 [citado 2019 Abril. 23];93(3):586-604. Available from: http://www.sciencedirect.com/science/article/pii/S0047272708001709. DOI: 10.1016/j.jpubec o.2008.10.009.

lamamoto MV. O Serviço Social na contemporaneidade: trabalho e formação profissional. São Paulo: Cortez, 2003.

Instituto Brasileiro de Geografia e Estatística. Campos Gerais. [citado 2019 Abril. 23]. Disponível em: http://cidades.ibge.gov.br/painel/painel.php?codmun=311160.

Pesquisa Nacional por Amostra de Domicílios. Síntese dos Indicadores 2011 [citado 2019 Abril. 23].. Rio de Janeiro, IBGE, 2012. Disponível em: http://www.ibge.gov.br/home/estatistica/pesquisas/pesquisa resultados.php?id pesquisa=40

Pesquisa Nacional por Amostra de Domicílios. Síntese dos Indicadores 2014[citado 2019 Abril. 23]. Rio de Janeiro, IBGE, 2015. Disponível em: http://www.ibge.gov.br/home/estatistica/pesquisas/pesquisa resultados.php?id pesquisa=40

Pesquisa Nacional por Amostra de Domicílios. Síntese dos Indicadores 2015. Rio de Janeiro, IBGE, 2016. Disponível em: http://www.ibge.gov.br/home/estatistica/pesquisas/pesquisa resultados.php?id pesquisa=40

Síntese de indicadores sociais: uma análise das condições de vida da população brasileira [citado 2019 Abril. 23]. Rio de Janeiro; 2013. Disponível em: http://biblioteca.ibge.gov.br/visualizacao/livros/liv66777.pdf.

Pesquisa Nacional por Amostra de Domicílios. Síntese dos Indicadores 2008 [citado 2019 Abril. 23].. Rio de Janeiro, IBGE, 2009. Disponível em: http://www.ibge.gov.br/home/estatistica/pesquisas/pesquisa resultados.php?id pesquisa $=40$

Pesquisa Nacional por Amostra de Domicílios. Síntese dos Indicadores 200 [citado 2019 Abril. 23]. 9. Rio de Janeiro, IBGE, 2010. Disponível em: http://www.ibge.gov.br/home/estatistica/pesquisas/pesquisa resultados.php?id pesquisa=40 
Pesquisa Nacional por Amostra de Domicílios. Síntese dos Indicadores 2005 [citado 2019 Abril. 23]. Rio de Janeiro, IBGE, 2006. Disponível em: http://www.ibge.gov.br/home/estatistica/pesquisas/pesquisa resultados.php?id pesquisa=40

Pesquisa Nacional por Amostra de Domicílios. Síntese dos Indicadores 2006 [citado 2019 Abril. 23]. Rio de Janeiro, IBGE, 2007. Disponível em: http://www.ibge.gov.br/home/estatistica/pesquisas/pesquisa resultados.php?id pesquisa=40

Pesquisa Nacional por Amostra de Domicílios. Síntese dos Indicadores 2007[citado 2019 Abril. 23]. Rio de Janeiro, IBGE, 2008. Disponível em: http://www.ibge.gov.br/home/estatistica/pesquisas/pesquisa resultados.php?id pesquisa=40

Pesquisa Nacional por Amostra de Domicílios. Síntese dos Indicadores 2004 [citado 2019 Abril. 23]. Rio de Janeiro, IBGE, 2005. Disponível em: http://www.ibge.gov.br/home/estatistica/pesquisas/pesquisa resultados.php?id pesquisa=40

O trabalho a partir dos 50 anos de idade. Pesquisa Mensal de Emprego [citado 2019 Abril. 23]. Rio de Janeiro, IBGE, 2012. Disponível em: http://www.ibge.gov.br/home/estatistica/indicadores/trabalhoerendimento/pme nova/trabalho 50anos.pdf.

Pesquisa Nacional por Amostra de Domicílios. Síntese dos Indicadores 2003 [citado 2019 Abril. 23]. Rio de Janeiro, IBGE, 2004. Disponível em: http://www.ibge.gov.br/home/estatistica/pesquisas/pesquisa resultados.php?id pesquisa=40

Mudança demográfica no Brasil no início do século XXI: subsídios para as projeções da população [cited 2017 May. 26]. Rio de Janeiro: IBGE, 2015. Available from: http://biblioteca.ibge.gov.br/visualizacao/livros/liv93322.pdf.

Pesquisa Mensal de Emprego [citado 2019 Abril. 23]. Rio de Janeiro, IBGE, fev., 2016. Disponível em: ftp://ftp.ibge.gov.br/Trabalho e Rendimento/Pesquisa Mensal de Emprego/fasciculo indic adores ibge/2016/pme 201602pubCompleta.pdf.

Pesquisa Nacional por Amostra de Domicílio Contínua: primeiro trimestre de 2017. [citado 2019 Abril. 23]. Brasília, 2017. Disponível em: ftp://ftp.ibge.gov.br/Trabalho e Rendimento/Pesquisa Nacional por Amostra de Domicilio s continua/Trimestral/Fasciculos Indicadores IBGE/pnadc 201701 trimestre caderno.pdf.

Rio de Janeiro, IBGE, dez. 2015. Disponível em: ftp://ftp.ibge.gov.br/Trabalho e Rendimento/Pesquisa Mensal de Emprego/fasciculo indic adores ibge/2015/pme 201512pubCompleta.pdf. 
Censo Demográfico 2010. Características gerais da população, religião e pessoas com deficiência [citado 2019 Abril. 23]. Rio de Janeiro. IBGE, 2010. p. 31. Disponível em: http://biblioteca.ibge.gov.br/visualizacao/periodicos/94/cd 2010 religiao deficiencia.pdf.

Instituto de Pesquisas Econômicas Aplicadas. Sociedade. A nova velha geração. Ano 4, edição 32. 2007 [citado 2019 Abril. 23]. Disponível em: http://www.ipea.gov.br/desafios/index.php?option=com content\&view=article\&id=1143:report agens-materias\&ltemid=39.

Jodelet $\mathrm{D}$. O movimento de retorno ao sujeito e a abordagem das representações sociais. Soc. estado [Internet]. 2009 [citado 2019 Abril. 23]; 24(3):679-712. Disponível em: http://www.scielo.br/scielo.php?script=sci arttext\&pid=S0102-

69922009000300004\&lng=en\&nrm=iso\&tlng=pt. DOI: 10.1590/S0102-69922009000300004.

Jodelet D. Representações sociais: um domínio em expansão [citado 2019 Abril. 23]. Tradução: Tarso Bonilha Mazzotti. UFRJ- Faculdade de Educação, dez. 1993. Disponível em: http://docplayer.com.br/36945-Representacoes-sociais-um-dominio-em-expansao-denisejodelet.html.

Kopiler DA. Atividade física na terceira idade. Rev. SOCERJ [Internet].1997 [citado 2019 Abril. 23];10(1). Disponível em: http://www.scielo.br/pdf/rbme/v3n4/a04v3n4.pdf.

Kubicek, B., Korunka, C., Raymo, J. M., \& Hoonakker, P. (2011). Psychological well-being in retirement: the effects of personal and gendered contextual resources. Journal of occupational health psychology, 16(2), 230-246. DOI:10.1037/a0022334.

Küchemann BA. Envelhecimento populacional, cuidado e cidadania: velhos dilemas e novos desafios. Sociedade e Estado, 27(1), 165-180. DOI: 10.1590/S0102-69922012000100010.

Lourenço RA, Veras RP. Mini-Exame do Estado Mental: características psicométicas em idosos ambulatoriais. Rev. Saúde Pública [Internet]. 2006 [citado 2019 Abril. 23];40(4):712719. Disponível em: http://www.scielo.br/scielo.php?script=sci arttext\&pid=S003489102006000500023. DOI: 10.1590/S0034-89102006000500023.

Lundgren AS, Liliequist E, Landén AS. Between activity and solidarity: Comprehending retirement and extended working lives in Swedish rural areas. 2018; 44(s/n): 1-8. DOI: 10.1016/j.jaging.2017.11.002.

Marques SC, Tyrrel MAR, Oliveira DC. A produção científica da enfermagem na perspectiva da representação social. Rev Latino-Am Enferm.[Internet]. 2006 [citado 2019 Abril. 23];14(5): 762-769. Disponível em: http://www.revistas.usp.br/rlae/article/viewFile/2360/2548. DOI: 10.1590/S0104-11692006000500019.

Martins SP. Prática Previdênciária. 2 ed. São Paulo: Editora Saraiva, 2016. 
McDonald S, O'Brien N, White M, Sniehotta FF. Changes in physical activity during the retirement transition: a theory-based, qualitative interview study. Int J Behav Nutr Phys Act. 2015; 12(25):1-12. DOI: 10.1186/s12966-015-0186-4.

Mendes MRSS, Gusmão JL, Faro ACM, Leite RCBO. A situação social do idoso no Brasil: uma breve consideração. Acta paul. Enferm [Internet]. 2005 [citado 2019 Abril. 23];18(4):422426. Disponível em: http://www.scielo.br/scielo.php?script=sci arttext\&pid=S010321002005000400011. DOI: 10.1590/S0103-21002005000400011.

Minayo MCS (org). Pesquisa social: teoria, método e criatividade. Rio de Janeiro: Vozes, 1994.

Minayo MCS. O desafio do conhecimento: pesquisa qualitativa em saúde. 9ed. São Paulo: Hucitec, 2006.

Miranda GMD, Mendes ACG, Silva ALA. Population aging in Brazil: current and future social challenges and consequences. Revista Brasileira de Geriatria e Gerontologia [Internet]. 2016 [citado 2019 Abri. 23]; 19(3):507-519. Disponível em: http://www.scielo.br/pdf/rbgg/v19n3/1809-9823-rbgg-19-03-00507.pdf.

Moreira JAC, Padilha MI, Silva DGV, Sapag J. Aspectos teóricos e metodológicos das representações sociais. Texto Contexto Enferm. [Internet] 2015 [citado 2019 Abril. 23]; 24(4): 1157-65. Disponível em: http://www.scielo.br/pdf/tce/v24n4/pt 0104-0707-tce-24-0401157.pdf. DOI: 10.1590/0104-0707201500003440014.

Moscovici S. Psicologia social: influencia y câmbios de actitudes, individuos y grupos. Barcelona (ES) [citado 2019 Abril. 23]: Paidós; 2005. Disponible en: https://www.researchgate.net/publication/31732502 Psicologia social influencia y cambio de actitudes individuos y grupos.

Moscovici S. Representações sociais: investigações em psicologia social. 9ed. Petrópolis: Vozes, 2012.

Nogueira-Martins MCF, Bógus CM. Considerações sobre a metodologia qualitativa como recurso para o estudo das ações de humanização em saúde. Saude soc. [Internet] 2004 [citado 2019 Abril. 23];13(3):44-57. Disponível em: http://www.scielo.br/pdf/sausoc/v13n3/06.pdf. DOI: 10.1590/S0104-12902004000300006.

Oliveira FO, Werba GC. Representações sociais. In: Jacques MG, Strey MN, Bernardes NMG. Psicologia social contemporânea. 6 ed. Petrópolis: Vozes; 2002. p. 104-117.

Organização Mundial da Saúde - OMS. Active Ageing - a policy framework. Second United Nations World Assembly on Ageing. Madrid; 2002 [cited 2017 May. 26]. Available from: http://whqlibdoc.who.int/hq/2002/who nmh nph 02.8.pdf. 
Padilha MICS, Guerreiro DMVS, Coelho MS. Aspectos teórico-metodológicos das representações sociais e seu uso na enfermagem. Online Braz J Nur [Internet]. 2007 [citado 2019 Abril. 23]; 6(2). Disponível em: http://www.objnursing.uff.br/index.php/nursing/article/view/j.1676-4285.2007.601/199.

Palinkas LA, Horwitz SM, Green CA, Wisdom JP, Duan N, Hoagwood K. Purposeful sampling for qualitative data collection and analysis in mixed method implementation research. Adm Policy Ment Health [Internet]. 2015 [citado 2019 Abril. 23]; 42(5):533-544. DOI: 10.1007/s10488-013-0528-y.

Paolini KS. Desafios da inclusão do idoso no mercado de trabalho. Rev Bras Med Trab [Internet]. 2016 [citado 2019 Abril. 23];14(2):177-82. Disponível em: http://132.248.9.34/hevila/Revistabrasileirademedicinadotrabalho/2016/vol14/no2/15.pdf.

DOI: 10.5327/Z1679-443520162915.

Patton MQ. Qualitative evaluation and research methods [cited 2017 May. 26]. Newbury Park, CA. Sage Publications, 1990. Available from: https://us.sagepub.com/enus/nam/node/52087/download-pdf.

Patton MQ. Qualitative research and evaluation methods. 3ed Sage Publications; Thousand Oaks, CA: 2002

Pissinati PSC, Haddad MCFL, Dalmas JC, Birolim MM. Fatores sociodemográficos e ocupacionais associados aos ganhos e perdas percebidos por trabalhadores de uma universidade pública frente à proximidade da aposentadoria. Cad. Saúde Pública. 2916; 32(9): e00141415. DOI: 10.1590/0102-311x00141415.

Polit D, Beck CT. Fundamentos de pesquisa em Enfermagem.7 ed. Porto Alegre: Editora Artmed, 2011.

Queiroz VS, Ramalho HMB, Cavalcanti GM. O emprego do idoso no mercado de trabalho: evidencias para o Brasil a partir da PNAD de 2005 [citado 2019 Abril. 23]. Disponível em: http://aplicativos.fipe.org.br/enaber/pdf/132.pdf.

Ramos EL, Souza NVDO, Caldas CP. Qualidade de vida do idoso trabalhador. Rev Enferm UERJ [Internet]. 2008 [citado 2019 Abril. 23];16(4):507-11. Disponível em: http://www.facenf.ueri.br/v16n4/v16n4a09.pdf.

Ramos LR, Veras RP, Kalache A. Envelhecimento populacional: uma realidade brasileira. Rev. Saúde Pública [Internet]. 1987 [cited 2019 Apr 23];21(3):211-224. DOI: 10.1590/S003489101987000300006.

Reigota M. Meio ambiente e representações sociais. São Paulo: Cortez, 1995 (questões da nossa época; $v, 41)$. 
Reis SLA, Bellini M. Representações sociais: teoria, procedimentos metodológicos e educação ambiental. Acta Scientiarum. Human and Social Sciences [Internet]. 2011 [citado 2019 Abril. 23];33(2):149-159. Disponível em: http://eduem.uem.br/ojs/index.php/ActaSciHumanSocSci/article/viewFile/10256/pdf. DOI: 10.4025/actascihumansoc.v33i2.10256.

Rodrigues M, Ayabe NH, Lunardelli MCF, Canêo LC. A preparação para a aposentadoria: o papel do psicólogo frente a essa questão. Rev. bras. orientac. Prof. [Internet]. 2005 [citado 2019 Abril. 23]; 6(1):53-62. Disponível em: http://pepsic.bvsalud.org/scielo.php?script=sci arttext\&pid=S1679-33902005000100006.

Rodrigues M, Ayabe NH, Lunardelli MCF, Canêo LC. A preparação para a aposentadoria: o papel do psicólogo frente a essa questão. Rev. bras. orientac. Prof. [Internet] 2005 [citado 2019 Abril. 23]. 6(1). 53-62. http://pepsic. bvsalud.org/scielo.php?script=sci arttext\&pid=S1679-33902005000100006.

Rodrigues RAP, Kusumota L, Marques S, Fabrício SCC, Rosset-Cruz I, Lange C. Política nacional de atenção ao idoso e a contribuição da enfermagem. Texto contexto - enferm. [Internet]. 2007 [cited 2019 Apr 23];16(3):536-545. DOI: 10.1590/S0104-07072007000300021.

Sadler GR, Lee HC, Lim RSH, Fullerton J. Recruitment of hard-to-reach population subgroups via adptations of the snowball sampling strategy. Nursing and Health Sciences [Internet]. 2010 [cited 2017 May. 26];12(3):369-374. Available from: https://www.ncbi.nlm.nih.gov/pmc/articles/PMC3222300. DOI: 10.1111/j.1442-2018.2010.00 541.x.

Santos MP. A teoria das representações sociais como referencial didático-metodológico de pesquisa no campo das ciências humanas e sociais aplicadas. Emancipação [Internet]. 2013 [citado 2019 Abril. 23];13(1): 9-2. Disponível em: http://www.revistas2.uepg.br/index.php/emancipacao/article/view/3122. DOI: 10.5212/Emancipacao.v.13i1.0001.

Schmitz LL. Do working conditions at older ages shape the health gradient? J Health Econ. 2016; 50(sn): 183-197. DOI: 10.1016/j.jhealeco.2016.10.002.

Sinclair D, Watson J, Beach B. Working longer: an EU perspective [cited 2017 May. 26]. ILC. Londres, 2013. Available from: http://www.ilcuk.org.uk/index.php/publications/publication details/working longer an eu perspective.

Souza AC, Melo CVB. O mercado de trabalho Brasileiro diante das perspectivas de envelhecimento da população. In: Brasil. Câmara dos Deputados. Centro de Estudos e Debates Estratégicos Brasil 2050: desafios de uma nação que envelhece. Brasília: Edições Câmara, 2017. 
Spink MJP. O conceito de representação social na abordagem psicossocial. Cad. Saúde Pública [Internet]. 1993 [citado 2019 Abril. 23];9(3):300-308. Disponível em: http://www.scielo.br/scielo.php?script=sci arttext\&pid=S0102-311X1993000300017\&lng=em \&nrm=iso\&tlng=pt. DOI: 10.1590/S0102-311X1993000300017.

Spradley JP. The ethnographic interview. Holt, Rinehart \& Winston; New York: 1979

Stenholm S, Solovieva S, Viikari-Juntura E, Aalto V, Kivimäki M, Vahtera J. Change in body mass index during transition to statutory retirement: an occupational cohort study. Int J Behav Nutr Phys Act. 2017; 14(1):1-8. DOI: 10.1186/s12966-017-0539-2.

Tang F, Chen H, Zhang Y, Mui AC. (2018). Employment and Life Satisfaction Among Middleand Old-Aged Adults in China. Gerontology \& geriatric medicine, 4, 2333721418778202. DOI:10.1177/2333721418778202.

Tateo L, lannaccone A. Social representations, individual and collective mind: A study of Wundt, Cattaneo and Moscovici. Integr Psychol Behav Sci [Internet]. 2012 [cited 2017 May. 26]; 46(1):57-69. Available from: https://link.springer.com/article/10.1007\%2Fs12124-0119162-y. DOI: 10.1007/s12124-011-9162-y.

Taylor AW, Pilkington R, Feist H, Dal Grande E, Hugo G. A survey of retirement intentions of baby boomers: an overview of health, social and economic determinants. BMC Public Health. 2014. 14(335): 1-9. DOI: 10.1186/1471-2458-14-355.

Torrely IWO. A influência do trabalho na qualidade de vida do idoso e na sintomatologia depressiva [Internet]. Porto Alegre: Gerontologia Biomédica, Pontifícia Universidade Católica; 2008 [citado 2019 Abril. 23]. Disponível em: http://tede2.pucrs.br/tede2/bitstream/tede/2577/1/407623.pdf.

Torres GV, Reis LA, Reis LA. Assessment of functional capacity in elderly residents of an outlying area in the hinterland of Bahia/Northeast Brazil. Arq. Neuro-Psiquiatr. [Internet] 2010 [cited 2017 May. 26];68(1):39-43. Available from: http://www.scielo.br/pdf/ anp/v68n1/a09v68n1.pdf. DOI: 10.1590/S0004-282X2010000100009.

Tossi M. Labor force projections to 2020: a more slowly growing workforce. Monthly Labor Review [Internet]. 2012 [cited 2017 May. 25], 43-64. Available from: https://www.bls.gov/opub/mlr/2012/01/art3full.pdf.

Uchôa E. Contribuições da antropologia para uma abordagem das questões relativas à saúde do idoso. Cad. Saúde Pública [Internet]. 2003 [cited 2019 Apr 23];19(3):849-853. DOI: 10.1590/S0102-311X2003000300017.

United Nations. Department of Economic and Social Affairs, Population Division. World Population Prospects: The 2012 Revision, United States; 2013 [cited 2017 May. 26]. Available from: https://esa.un.org/unpd/wpp/publications/Files/WPP2012 HIGHLIGHTS.pdf. 
World Population Prospects:

The 2015 Revision, United States; 2015 [cited 2017 May. 26]. Available from: https://esa.un.org/unpd/wpp/publications/files/key findings wpp 2015.pdf.

Veras RP. Envelhecimento populacional contemporâneo: demandas, desafios e inovações. Rev Saúde Pública [Internet]. 2009 [citado 2019 Abril. 23];43(3):548-554. Available from: http://www.scielosp.org/pdf/rsp/v43n3/224.pdf. DOI: 10.1590/S0034-89102009005000025.

Virtanen M, Ferrie JE, Batty GD, Elovainio M, Jokela M, Vahtera J et al. Socioeconomic and Psychosocial Adversity in Midlife and Depressive Symptoms Post Retirement: A 21-year Follow-up of the Whitehall II Study. Am J Geriatr Psychiatry. 2015; 23(1): 99-109. DOI: 10.1016/j.jagp.2014.04.001.

Wajnman S, Oliveira AMHC, Oliveira EL. Os idosos no mercado de trabalho: tendências e consequências. In: Camarano AA (org.). Os novos idosos brasileiros: muito além dos 60 anos. Rio de Janeiro: IPEA; 2004.

Wong LLR, Carvalho JAM. O rápido processo de envelhecimento populacional no Brasil: sérios desafios para as políticas públicas. Rev. bras. estud. Popul [Internet] 2006[citado 2019 Abril. 23];23(1):5. Disponível em: http://www.scielo.br/scielo.php?script=sci arttext\&pid= S0102-30982006000100002. DOI: 10.1590/S0102-30982006000100002.

World Health Organization. Envelhecimento ativo: uma política de saúde [citado 2019 Abril. 23]. Brasília: Organização Pan-Americana da Saúde, 2005. Disponível em: http://bvsms.saude.gov.br/bvs/publicacoes/envelhecimento ativo.pdf. 


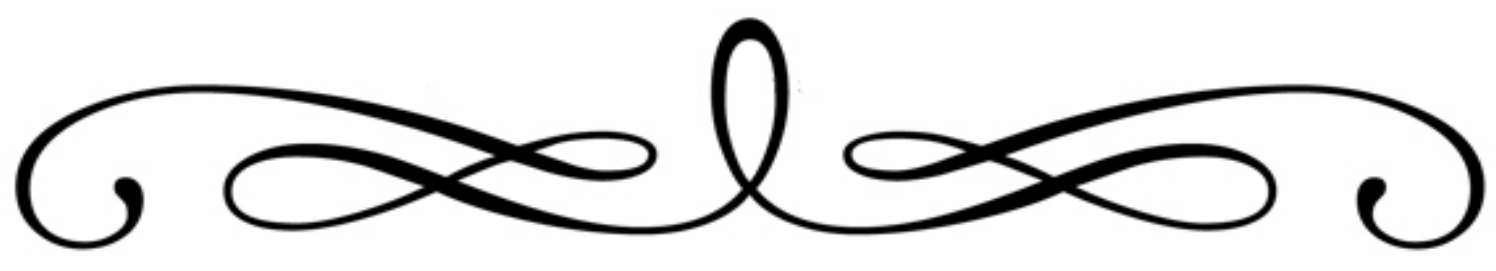

APÊNDICES

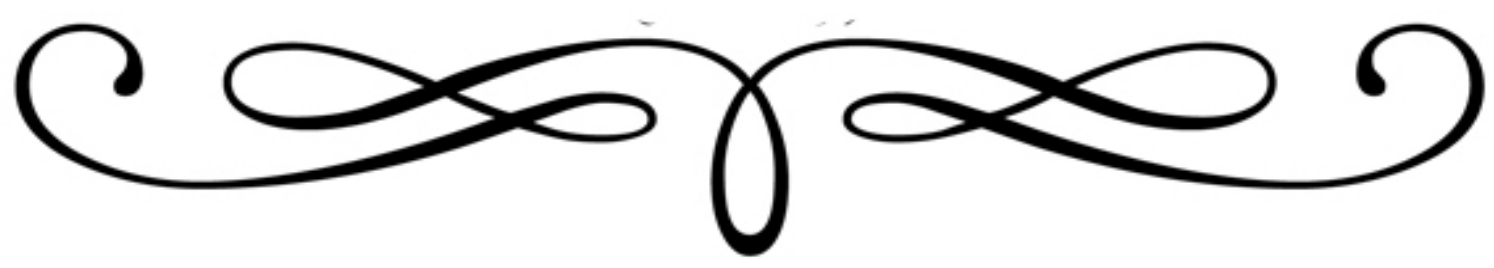




\section{APÊNDICE A - TERMO DE CONSENTIMENTO LIVRE E ESCLARECIDO - TCLE}
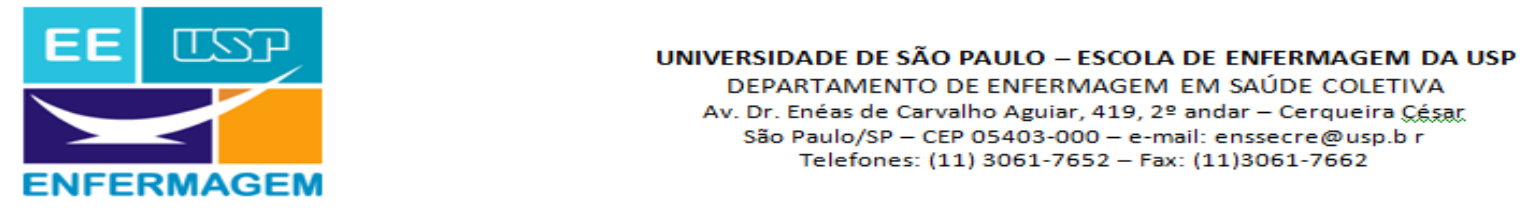

\section{Pesquisa - Trabalho e aposentadoria: a busca de seus significados entre idosos jovens}

\section{TERMO DE CONSENTIMENTO LIVRE E ESCLARECIDO}

Estou convidando você para participar de forma voluntária e não remunerada da pesquisa: TRABALHO E APOSENTADORIA: A BUSCA DE SEUS SIGNIFICADOS ENTRE IDOSOS JOVENS, que tem como objetivo compreender o que significa trabalhar e aposentar para os idosos que moram na cidade e na zona rural. Esse estudo se justifica devido o aumento no número de pessoas idosas que continuam inseridas no mercado de trabalho mesmo após terem atingido a idade mínima de aposentadoria.

Solicito sua colaboração para responder aos questionários e uma entrevista, em dois dias, que levarão em média 40 minutos cada. Os riscos desta entrevista são o desgaste físico e o emocional, onde o (a) senhor (a) poderá solicitar o término das atividades quando se sentir cansado e assim agendaremos uma nova data e horário para que possamos retomar sua participação. Além disso, caso suas lembranças vierem à tona e lhe causarem algum tipo de desconforto, nosso encontro poderá ser interrompido e me comprometo a acolhê-lo e providenciar se necessário, seu encaminhamento ao serviço de Psicologia da Unidade de Referência.

A entrevista é sigilosa e será gravada. Todos seus dados são confidenciais e você não será identificado. Você pode desistir de participar desta pesquisa a qualquer momento sem que haja qualquer tipo de prejuízo em nosso relacionamento.

Os benefícios desta pesquisa poderão contribuir para o fortalecimento das políticas públicas que enfatizam o Envelhecimento Ativo e a garantia dos direitos trabalhistas e previdenciários já previstos nas leis brasileiras de proteção ao idoso.

Os dados coletados serão utilizados somente para a pesquisa, e os resultados poderão ser veiculados por meio de artigos científicos em revistas especializadas e/ou eventos científicos, sempre resguardando sua identidade.

Em qualquer etapa do estudo, você poderá tirar suas dúvidas, entrando em contato com os pesquisadores responsáveis. O pesquisador principal é o enfermeiro João Henrique de Morais Ribeiro que pode ser encontrado à Rua Joaquim Manoel de Figueiredo, $n^{\circ} 43$, Centro - CEP: $37.160-000$ na cidade de Campos Gerais/MG, pelos telefones: (11) 94628-8545 ou (35) 98838-7738 e-mail: joaoh.mribeiro@usp.br ou com 
a Prof $^{a} \operatorname{Dr}^{\mathrm{a}}$. Suely Itsuko Ciosak pelo telefone (11) 3061-7652, e-mail: siciosak@usp.br.

Caso você tenha alguma consideração ou dúvida sobre a ética da pesquisa, o (a) senhor (a) pode contatar o Comitê de Ética em Pesquisa (CEP) da Escola de Enfermagem da USP, à Av. Dr. Enéas de Carvalho Aguiar 419, Bairro Cerqueira Cesar CEP: 05.403-000 - São Paulo/SP ou pelo telefone (11) 3061-8858, e-mail: cepee@usp.br.

Este termo será rubricado em todas as suas páginas e assinado em duas vias, sendo que uma delas será disponibilizada para o (a) senhor (a).

Esta pesquisa atende todas as especificações da Resolução 466, de 12 de dezembro de 2012 que aprova as diretrizes e normas regulamentadoras de pesquisas envolvendo seres humanos. de de 2018. 
APÊNDICE B - CARACTERIZAÇÃO SOCIOECONÔMICA, DEMOGRÁFICA E CONDIÇÕES DE SAÚDE DOS INDIVÍDUOS IDOSOS

\begin{tabular}{|c|c|c|c|c|}
\hline $\begin{array}{l}\text { Identificação do } \\
\text { Participante }\end{array}$ & & & Data da coleta: & \\
\hline \multicolumn{5}{|c|}{ 1. Condições socioeconômicas, demográficas e de trabalho } \\
\hline \multicolumn{5}{|l|}{ Data de Nascimento } \\
\hline Sexo & ( ) Masculino & ( ) Feminino & & \\
\hline Estado Civil & ( ) Solteiro (a) & $\begin{array}{l}\text { ( ) Casado/União } \\
\text { estável }\end{array}$ & $\begin{array}{l}\text { ( ) Separado/ } \\
\text { Divorciado }\end{array}$ & ( ) viúvo (a) \\
\hline Cor auto atribuída & ( ) Branca & ( ) Preta & ( ) Amarela & ( )Parda \\
\hline Religião & ( ) Católico & ( ) Evangélica & ( ) Espírita & ( ) Outra \\
\hline Escolaridade & ( ) Analfabeto & $\begin{array}{l}\text { ( ) } 1 \text { a } 3 \text { anos de } \\
\text { estudo }\end{array}$ & $\begin{array}{l}\text { ( ) } 4 \text { a } 7 \text { anos de } \\
\text { estudo }\end{array}$ & $\begin{array}{l}\text { ( ) Mais de } 7 \text { anos de } \\
\text { estudo }\end{array}$ \\
\hline Renda familiar & $\begin{array}{l}\text { ( ) Menor que } \\
\text { um SM }\end{array}$ & ( ) de 1 até 3 SM & ( ) de 4 a 6 SM & ( ) Mais de $7 \mathrm{SM}$ \\
\hline Moradia & ( ) Própria & ( ) Alugada & ( ) Cedida & ( ) Outro. Especificar \\
\hline $\begin{array}{l}\text { Número de } \\
\text { dependentes da renda }\end{array}$ & ( ) Nenhuma & ( ) 1 pessoa & $\begin{array}{l}(\quad) \text { de } 2 \text { a } 4 \\
\text { pessoas }\end{array}$ & ( ) Mais de 5 pessoas \\
\hline Arranjo familiar & $\begin{array}{l}\text { ( ) Mora } \\
\text { sozinho }\end{array}$ & ( ) Com esposo & ( ) Com filhos & $\begin{array}{l}\text { ( ) Com esposo mais } \\
\text { filhos }\end{array}$ \\
\hline $\begin{array}{l}\text { Situação atual de } \\
\text { trabalho }\end{array}$ & $\begin{array}{l}\text { ( ) trabalho } \\
\text { formal }\end{array}$ & $\begin{array}{l}\text { ( ) trabalho } \\
\text { informal/voluntário }\end{array}$ & ( ) Aposentado & ( ) Pensionista/BPC \\
\hline \multicolumn{5}{|l|}{ Profissão } \\
\hline $\begin{array}{l}\text { Capacidade para } \\
\text { trabalhar }\end{array}$ & ( ) Ótima & ( ) Boa & ( ) Moderada & ( ) Baixa \\
\hline $\begin{array}{l}\text { Faltava com frequência } \\
\text { ao trabalho }\end{array}$ & ( ) Sim & ( ) Não & \multicolumn{2}{|c|}{ Se sim, indicar os motivos: } \\
\hline Local de Moradia & $\begin{array}{l}\text { ( ) Área } \\
\text { urbana }\end{array}$ & ( ) Área rural & & \\
\hline $\begin{array}{l}\text { Participação em } \\
\text { atividades sociais }\end{array}$ & ( ) Sim & ( ） Não & Se sim: & 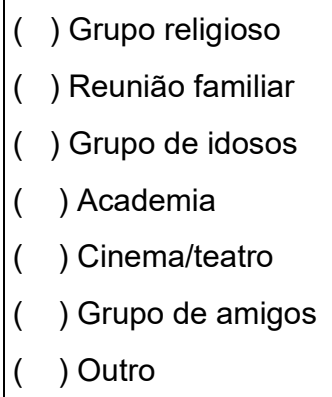 \\
\hline
\end{tabular}




\begin{tabular}{|l|l|l|l|l|}
\hline \multicolumn{2}{|l|}{ 2. Condições de saúde } & ( ) Regular & ( ) Ruim/Muito ruim \\
\hline $\begin{array}{l}\text { Em geral, o senhor diria } \\
\text { que sua saúde é }\end{array}$ & ( ) Muito boa & ( ) Boa & Se sim: & $\begin{array}{l}\text { Há quanto tempo fuma? } \\
\text { Quantos cigarros por } \\
\text { dia? }\end{array}$ \\
\hline Tipo de cigarro
\end{tabular}




\section{APÊNDICE C - ROTEIRO DE ENTREVISTA}

\section{Data:}

\section{Iniciais:}

\section{Horário:}

- O que significa trabalho/trabalhar para o senhor (a)?

- O que significa aposentadoria/aposentar para o senhor (a)?

- Muitas pessoas quando completam seus 60/65 anos já se aposentaram e o (a) senhor (a) continua trabalhando. O que o (a) leva a continuar?

- Tem pretensão de continuar trabalhando até quando?

\section{Complemento}

- Quando chegou a hora para se aposentar, o que passava pela sua cabeça?

- Conte-me como foi seu processo de aposentadoria.

- Depois de aposentado, sentiu ou sente falta da rotina e das atribuições do seu trabalho? O que tem feito atualmente no dia a dia? 


\section{APÊNDICE D - CÓDIGOS REFERENTES AOS IDOSOS \\ PARTICIPANTES DO ESTUDO. SÃO PAULO, 2019}

\begin{tabular}{cc}
\hline Identificação & Situação Atual de trabalho \\
\hline ID 01 & Aposentado \\
ID 02 & Trabalho formal \\
ID 03 & Aposentado \\
ID 04 & Trabalho formal \\
ID 05 & Trabalho formal \\
ID 06 & Aposentado \\
ID 07 & Aposentado \\
ID 08 & Aposentado \\
ID 09 & Aposentado \\
ID 10 & Aposentado \\
ID 11 & Aposentado \\
ID 12 & Aposentado \\
ID 13 & Aposentado \\
ID 14 & Aposentado \\
ID 15 & Aposentado \\
ID 16 & Aposentado \\
ID 17 & Trabalho formal \\
ID 18 & Aposentado \\
ID 19 & Aposentado \\
ID 20 & Aposentado \\
ID 21 & Aposentado \\
ID 22 & Aposentado \\
\hline
\end{tabular}

\begin{tabular}{cc}
\hline Identificação & Situação Atual de trabalho \\
\hline IDSP 01 & Trabalho formal \\
IDSP 02 & Aposentado \\
IDSP 03 & Aposentado \\
IDSP 04 & Trabalho voluntário \\
IDSP 05 & Trabalho voluntário \\
IDSP 06 & Trabalho formal \\
IDSP 07 & Aposentado \\
IDSP 08 & Aposentado \\
IDSP 09 & Aposentado \\
IDSP 10 & Aposentado \\
IDSP 11 & Trabalho formal \\
IDSP 12 & Aposentado \\
IDSP 13 & Aposentado \\
IDSP 14 & Trabalho formal \\
IDSP 15 & Trabalho formal \\
IDSP 16 & Aposentado \\
IDSP 17 & Aposentado \\
IDSP 18 & Aposentado \\
IDSP 19 & Aposentado \\
IDSP 20 & Aposentado \\
IDSP 21 & Aposentado \\
IDSP 22 & Aposentado \\
\hline
\end{tabular}




\section{APÊNDICE E - RASTREIO COGNITIVO, FUNCIONAL E DE HUMOR DOS IDOSOS JOVENS. SÃO PAULO, 2019}

\begin{tabular}{|c|c|c|c|c|c|}
\hline IDADE & SEXO & ESCOLARIDADE & MEEM $^{1}$ & LAWTON & EDG $^{2}-15$ \\
\hline 65 & Feminino & 1 a 3 anos & 29 & 25 & 0 \\
\hline 70 & Masculino & 1 a 3 anos & 28 & 24 & 1 \\
\hline 70 & Masculino & 1 a 3 anos & 28 & 24 & 1 \\
\hline 69 & Masculino & 4 a 7 anos & 30 & 27 & 2 \\
\hline 61 & Feminino & 4 a 7 anos & 32 & 27 & 4 \\
\hline 62 & Feminino & 4 a 7 anos & 31 & 26 & 2 \\
\hline 68 & Masculino & 4 a 7 anos & 31 & 27 & 0 \\
\hline 69 & Masculino & 4 a 7 anos & 30 & 27 & 2 \\
\hline 70 & Masculino & Mais de 7 anos & 26 & 27 & 1 \\
\hline 60 & Feminino & Mais de 7 anos & 32 & 27 & 0 \\
\hline 64 & Feminino & Mais de 7 anos & 27 & 27 & 2 \\
\hline 61 & Masculino & Mais de 7 anos & 31 & 27 & 2 \\
\hline 65 & Masculino & Mais de 7 anos & 32 & 27 & 1 \\
\hline 66 & Feminino & Mais de 7 anos & 27 & 27 & 2 \\
\hline 61 & Feminino & Mais de 7 anos & 29 & 27 & 1 \\
\hline 65 & Feminino & Mais de 7 anos & 30 & 26 & 0 \\
\hline 70 & Masculino & Mais de 7 anos & 29 & 27 & 1 \\
\hline 66 & Feminino & Mais de 7 anos & 29 & 27 & 3 \\
\hline 68 & Feminino & Mais de 7 anos & 31 & 27 & 1 \\
\hline 64 & Feminino & Mais de 7 anos & 31 & 27 & 2 \\
\hline 67 & Masculino & Mais de 7 anos & 31 & 27 & 0 \\
\hline 60 & Feminino & Mais de 7 anos & 31 & 27 & 3 \\
\hline 70 & Masculino & Mais de 7 anos & 31 & 27 & 1 \\
\hline 66 & Feminino & Mais de 7 anos & 31 & 27 & 2 \\
\hline 66 & Feminino & Mais de 7 anos & 26 & 27 & 5 \\
\hline 70 & Feminino & Mais de 7 anos & 30 & 27 & 2 \\
\hline 70 & Feminino & Mais de 7 anos & 30 & 27 & 1 \\
\hline 67 & Feminino & Mais de 7 anos & 27 & 27 & 4 \\
\hline 69 & Feminino & Mais de 7 anos & 26 & 27 & 1 \\
\hline 69 & Feminino & Mais de 7 anos & 30 & 27 & 2 \\
\hline 69 & Feminino & Mais de 7 anos & 28 & 27 & 5 \\
\hline 69 & Feminino & Mais de 7 anos & 30 & 27 & 1 \\
\hline 68 & Masculino & Mais de 7 anos & 27 & 27 & 3 \\
\hline 60 & Feminino & Mais de 7 anos & 31 & 27 & 6 \\
\hline 68 & Feminino & Mais de 7 anos & 26 & 27 & 1 \\
\hline 65 & Feminino & Mais de 7 anos & 31 & 27 & 0 \\
\hline 69 & Feminino & Mais de 7 anos & 31 & 27 & 2 \\
\hline 70 & Feminino & Mais de 7 anos & 31 & 27 & 2 \\
\hline 68 & Masculino & Mais de 7 anos & 27 & 27 & 1 \\
\hline 60 & Feminino & Mais de 7 anos & 31 & 27 & 2 \\
\hline 68 & Feminino & Mais de 7 anos & 26 & 27 & 1 \\
\hline 65 & Masculino & Mais de 7 anos & 32 & 26 & 0 \\
\hline 66 & Feminino & Mais de 7 anos & 27 & 27 & 1 \\
\hline 61 & Feminino & Mais de 7 anos & 29 & 27 & 3 \\
\hline
\end{tabular}

Legenda:

${ }^{1}$ MEEM: Mini Exame do Estado Mental

${ }^{2}$ EDG: Escala de Depressão Geriátrica 


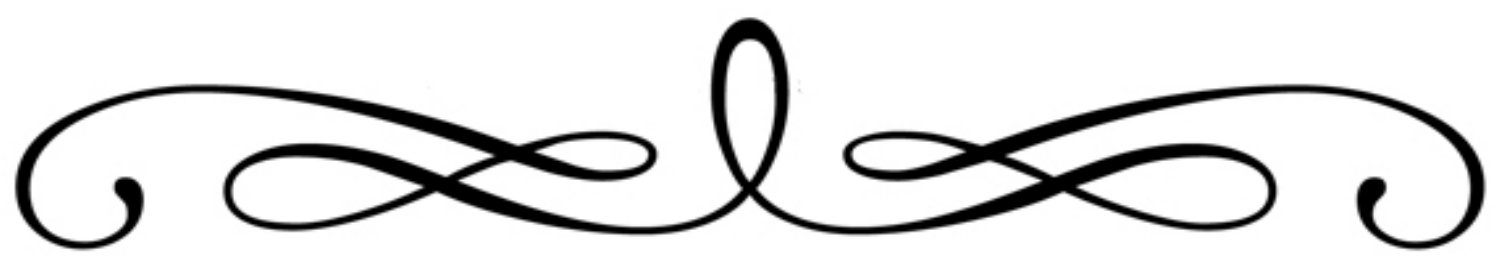

ANEXOS

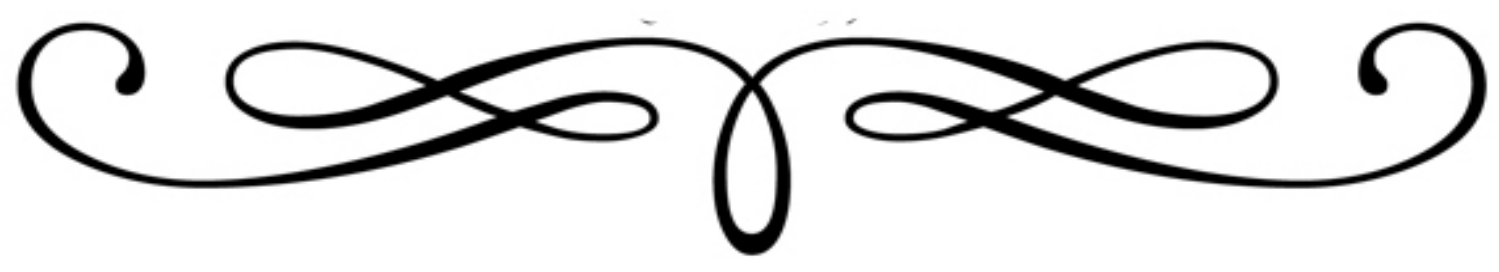


ANEXO 1 - MINI EXAME DO ESTADO MENTAL

\begin{tabular}{|c|c|c|c|}
\hline $\begin{array}{l}\text { 1. Orientação } \\
\text { temporal (0 -5 } \\
\text { pontos) }\end{array}$ & Em que dia estamos? & \begin{tabular}{|l} 
Ano \\
Semestre \\
Mês \\
Dia \\
Dia da semana
\end{tabular} & $\begin{array}{l}1 \\
1 \\
1 \\
1 \\
1\end{array}$ \\
\hline \begin{tabular}{|l|} 
2. Orientação \\
espacial ( $0-5$ pontos $)$
\end{tabular} & Onde estamos? & \begin{tabular}{|l|} 
Estado \\
Cidade \\
Bairro \\
Rua \\
Local \\
\end{tabular} & $\begin{array}{l}1 \\
1 \\
1 \\
1 \\
1\end{array}$ \\
\hline $\begin{array}{l}\text { 3. Repita as palavras } \\
\text { ( } 0-3 \text { pontos })\end{array}$ & $\begin{array}{l}\text { Peça ao idoso para repetir as palavras depois de dizê- } \\
\text { las. Repita todos os objetos até que o entrevistado o } \\
\text { aprenda (máximo de } 5 \text { repetições) }\end{array}$ & $\begin{array}{l}\text { Caneca } \\
\text { Tijolo } \\
\text { Tapete }\end{array}$ & $\begin{array}{l}1 \\
1 \\
1\end{array}$ \\
\hline 4. Cálculo & O (a) senhor (a) faz cálculos? & $\begin{array}{l}\text { Sim (vá para 4a) } \\
\text { Não (vá para 4b) }\end{array}$ & $\begin{array}{l}1 \\
1\end{array}$ \\
\hline $\begin{array}{l}\text { 4a. Cálculo (0 -5 } \\
\text { pontos) }\end{array}$ & $\begin{array}{l}\text { Se de } R \$ 100,00 \text { fossem tirados } R \$ 7,00 \text { quanto } \\
\text { restaria? E se tirarmos mais } R \$ 7,00 \text { ? (total } 5 \\
\text { subtrações) }\end{array}$ & $\begin{array}{l}93 \\
86 \\
79 \\
72 \\
65\end{array}$ & $\begin{array}{l}1 \\
1 \\
1 \\
1 \\
1\end{array}$ \\
\hline $4 \mathrm{~b}$. & Soletre a palavra MUNDO de trás para frente & $\begin{array}{l}O \\
D \\
N \\
U \\
M\end{array}$ & $\begin{array}{l}1 \\
1 \\
1 \\
1 \\
1\end{array}$ \\
\hline 5. Memorização & Repita as palavras que disse há pouco & $\begin{array}{l}\text { Caneca } \\
\text { Tijolo } \\
\text { Tapete } \\
\end{array}$ & $\begin{array}{l}1 \\
1 \\
1\end{array}$ \\
\hline $\begin{array}{l}\text { 6. Linguagem }(0-3 \\
\text { pontos) }\end{array}$ & $\begin{array}{l}\text { Mostre um relógio e uma caneta e peça ao idoso para } \\
\text { nomeá-los. }\end{array}$ & $\begin{array}{l}\text { Relógio } \\
\text { Caneta }\end{array}$ & $\begin{array}{l}1 \\
1\end{array}$ \\
\hline $\begin{array}{l}\text { 7. Linguagem (1 } \\
\text { ponto) }\end{array}$ & Repita a frase & $\begin{array}{l}\text { NEM AQUI, NEM } \\
\text { ALI, NEM LÁ }\end{array}$ & 1 \\
\hline $\begin{array}{l}\text { 8. Linguagem }(0-2 \\
\text { pontos) }\end{array}$ & Siga uma ordem de três estágios & $\begin{array}{l}\text { Pegue o papel } \\
\text { com a mão direita } \\
\text { Dobre-o ao meio } \\
\text { Ponha-o no chão }\end{array}$ & $\begin{array}{l}1 \\
1 \\
1\end{array}$ \\
\hline $\begin{array}{l}\text { 9. Linguagem (1 } \\
\text { ponto) }\end{array}$ & $\begin{array}{l}\text { Escreva em um papel: "feche os olhos". Peça ao } \\
\text { idoso para que leia a ordem e a execute }\end{array}$ & $\begin{array}{l}\text { FECHE OS } \\
\text { OLHOS }\end{array}$ & 1 \\
\hline $\begin{array}{l}\text { 10. Linguagem (1 } \\
\text { ponto) }\end{array}$ & Peça ao idoso para escrever uma frase completa. & & 1 \\
\hline $\begin{array}{l}\text { 11. Linguagem (1 } \\
\text { ponto) }\end{array}$ & Copie o desenho & & 1 \\
\hline
\end{tabular}

Fonte: Brasil, 2006. 
ANEXO 2 - ESCALA DE LAWTON

\begin{tabular}{|c|c|c|c|}
\hline \multicolumn{2}{|c|}{ ATIVIDADE } & \multicolumn{2}{|l|}{ AVALIAÇÃO } \\
\hline 1 & O (a) senhor (a) consegue usar o telefone? & $\begin{array}{l}\text { Sem ajuda } \\
\text { Com ajuda parcial } \\
\text { Não consegue }\end{array}$ & $\begin{array}{l}3 \\
2 \\
1\end{array}$ \\
\hline 2 & $\begin{array}{l}\text { O (a) senhor (a) consegue ir a locais distantes, } \\
\text { usando algum transporte, sem necessidade de } \\
\text { planejamentos especiais? }\end{array}$ & $\begin{array}{l}\text { Sem ajuda } \\
\text { Com ajuda parcial } \\
\text { Não consegue }\end{array}$ & $\begin{array}{l}3 \\
2 \\
1\end{array}$ \\
\hline 3 & O (a) senhor (a) consegue fazer compra? & $\begin{array}{l}\text { Sem ajuda } \\
\text { Com ajuda parcial } \\
\text { Não consegue }\end{array}$ & $\begin{array}{l}3 \\
2 \\
1\end{array}$ \\
\hline 4 & $\begin{array}{l}\text { O (a) senhor (a) consegue preparar suas próprias } \\
\text { refeições? }\end{array}$ & $\begin{array}{l}\text { Sem ajuda } \\
\text { Com ajuda parcial } \\
\text { Não consegue }\end{array}$ & $\begin{array}{l}3 \\
2 \\
1\end{array}$ \\
\hline 5 & O (a) senhor (a) consegue arrumar a casa? & $\begin{array}{l}\text { Sem ajuda } \\
\text { Com ajuda parcial } \\
\text { Não consegue }\end{array}$ & $\begin{array}{l}3 \\
2 \\
1\end{array}$ \\
\hline 6 & $\begin{array}{l}\text { O (a) senhor (a) consegue fazer trabalhos manuais } \\
\text { domésticos, com pequenos reparos? }\end{array}$ & $\begin{array}{l}\text { Sem ajuda } \\
\text { Com ajuda parcial } \\
\text { Não consegue }\end{array}$ & $\begin{array}{l}3 \\
2 \\
1\end{array}$ \\
\hline 7 & $\begin{array}{l}\text { O (a) senhor (a) consegue lavar e passar suas } \\
\text { roupas? }\end{array}$ & $\begin{array}{l}\text { Sem ajuda } \\
\text { Com ajuda parcial } \\
\text { Não consegue }\end{array}$ & $\begin{array}{l}3 \\
2 \\
1\end{array}$ \\
\hline 8 & $\begin{array}{l}\text { O (a) senhor (a) consegue tomar seus remédios na } \\
\text { dose e horários corretos? }\end{array}$ & $\begin{array}{l}\text { Sem ajuda } \\
\text { Com ajuda parcial } \\
\text { Não consegue }\end{array}$ & $\begin{array}{l}3 \\
2 \\
1\end{array}$ \\
\hline 9 & O (a) senhor (a) consegue cuidar de suas finanças? & $\begin{array}{l}\text { Sem ajuda } \\
\text { Com ajuda parcial } \\
\text { Não consegue }\end{array}$ & $\begin{array}{l}3 \\
2 \\
1\end{array}$ \\
\hline & TTAL & & $\overline{\text { pontos }}$ \\
\hline
\end{tabular}

Fonte: Brasil, 2006. 
ANEXO 3 - ESCALA DE DEPRESSÃO GERIÁTRICA (EDG) 15 itens

\begin{tabular}{|c|c|c|c|}
\hline 1 & Está satisfeito (a) com sua vida? & ( ) Sim & ( ) Não \\
\hline 2 & Interrompeu muitas de suas atividades? & ( ) Sim & ( ) Não \\
\hline 3 & Acha sua vida vazia? & ( ) Sim & ( ) Não \\
\hline 4 & Aborrece-se com frequência? & ( ) Sim & ( ) Não \\
\hline 5 & Sente-se bem com a vida na maior parte do tempo? & ( ) Sim & ( ) Não \\
\hline 6 & Teme que algo ruim Ihe aconteça? & ( ) Sim & ( ) Não \\
\hline 7 & Sente-se alegre a maior parte do tempo? & ( ) Sim & ( ) Não \\
\hline 8 & Sente-se desamparado com frequência? & ( ) Sim & ( ) Não \\
\hline 9 & Prefere ficar em casa a sair e fazer coisas novas? & ( ) Sim & ( ) Não \\
\hline 10 & $\begin{array}{l}\text { Acha que tem mais problemas de memória que outras } \\
\text { pessoas? }\end{array}$ & ( ) $\operatorname{Sim}$ & ( ) Não \\
\hline 11 & Acha que é maravilhoso estar vivo (a)? & ( ) Sim & ( ) Não \\
\hline 12 & Sente-se inútil? & ( ) Sim & ( ) Não \\
\hline 13 & Sente-se cheio/a de energia? & ( ) Sim & ( ) Não \\
\hline 14 & Sente-se sem esperança? & ( ) Sim & ( ) Não \\
\hline 15 & Acha que os outros têm mais sorte que você? & ( ) Sim & ( ) Não \\
\hline
\end{tabular}

Fonte: Brasil, 2006. 


\section{ANEXO 4 - PARECER DO COMITÊ DE ÉTICA EM PESQUISA DA EEUSP}

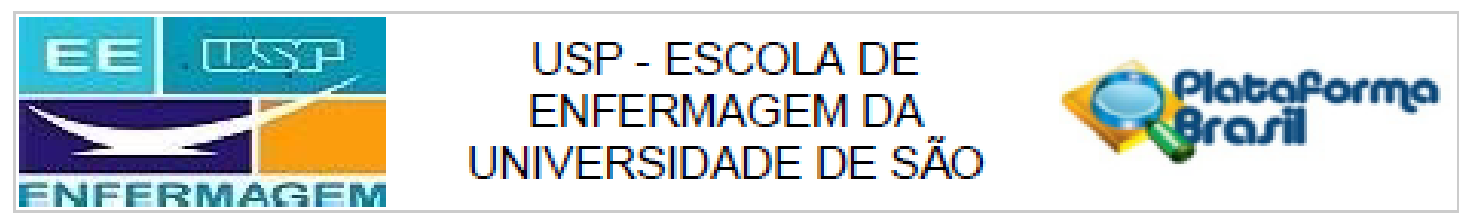

PARECER CONSUBSTANCIADO DO CEP

\section{DADOS DO PROJETO DE PESQUISA}

Título da Pesquisa: Trabalho e aposentadoria: a busca de seus significados entre idosos jovens

Pesquisador: Joäo Henrique de Morais Ribeiro

Área Temática:

Versão: 1

CAAE: 79330817.3 .0000 .5392

Instituição Proponente: Escola de Enfermagem da USP

Patrocinador Principal: Financiamento Próprio

\section{DADOS DO PARECER}

\section{Número do Parecer: 2.384.277}

\section{Apresentação do Projeto:}

Trata-se de um projeto de pesquisa apresentado ao Programa Interunidades de Doutoramento em Enfermagem da Escola de Enfermagem da Universidade de São Paulo e Escola de Enfermagem de Ribeirão Preto da Universidade de São Paulo do aluno João Henrique de Morais Ribeiro, sob orientação da Profa Dra Suely Itsuko Ciosak. A pesquisa tem como foco o envelhecimento da população, o aumento de pessoas idosas atuando no mercado de trabalho brasileiro e o possivel reflexo da aposentadoria na vida dos idosos. Neste contexto, o estudo tem como proposta responder às seguintes indagaçöes: por que alguns idosos optam pela aposentadoria? O que os faz continuar trabalhando? $O$ que significa trabalho e aposentaria para eles? Existem diferenças na capacidade funcional e na tendência para depressão entre os idosos jovens que continuaram trabalhando em relação àqueles que se aposentaram? Para tanto, será realizada uma pesquisa exploratória, prospectiva, de abordagem metodológica quantitativa e qualitativa e a Teoria das Representações Sociais será adotada como referencial teórico para a compreensäo do fenômeno. O estudo será desenvolvido em Campos Gerais - Minas Gerais, no meio urbano e rural, com uma amostra de 200 idosos, de ambos os sexos, aposentados ou não, que atenderem aos seguintes critérios: ter idade entre 60 e 70 anos (considerados idosos jovens); ter capacidade de comunicar-se verbalmente, isto é, lúcidos e não portadores de desordens cognitivas; e residir nas áreas urbana ou rural. Os participantes do estudo (selecionados por meio do método da Amostragem Intencional) serão localizados nas praças públicas, em seus domicílios, locais de trabalho, igrejas e

Endereço: Av. Dr. Eneas de Carvalho Agular, 419 Bairro: Cerqueira Cesar

UF: SP Municiplo: SAO PAULO

CEP: $\quad 05.403-000$

Telefone: (11)3061-8858

E-mall: cepeedusp.br 


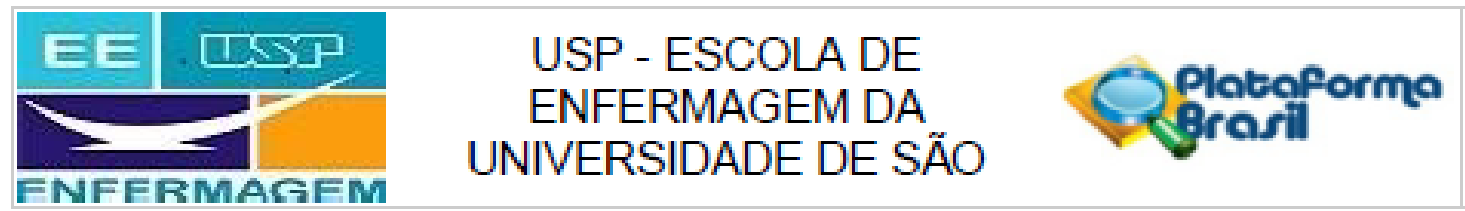

Continusç50 do Parecer: 2.384 .277

em outros locais onde haja aglomeração de pessoas idosas. As variáveis analisadas contemplarão caracterização socioeconômica, demográfica e condições de saúde dos indivíduos, avaliação do comprometimento cognitivo (mini exame do estado mental), do desempenho funcional para a realização de atividades instrumentais da vida diária (Escala de Lawton) e de depressão (Escala de Depressão Geriátrica). além da aplicação de questões abertas relacionadas ao trabalho e aposentadoria. A entrevista será realizada em duas etapas (de 40 minutos cada). Na primeira será realizado o preenchimento dos instrumentos. Na segunda, procederá a entrevista gravada. Para as variáveis quantitativas, serão aplicados testes estatísticos de acordo com a normalidade dos dados coletados. A técnica de Análise de Conteúdo de Bardin será adotada para análise do conteúdo dos depoimentos.

\section{Objetivo da Pesquisa:}

Objetivo geral: identificar e analisar os significados de trabalho e aposentadoria para o idoso jovem. Objetivos específicos: caracterizar o perfil sociodemográfico, condição de saúde e a capacidade funcional dos idosos jovens do meio urbano e rural; identificar os significados do trabalho e aposentadoria para os idosos jovens; verificar associação entre as condições socioeconômicas, a capacidade funcional e a depressão entre idosos jovens; e identificar as limitações e capacidades dos idosos jovens frente ao trabalho e a aposentadoria.

\section{Avaliação dos Riscos e Benefícios:}

Os riscos da pesquisa estäo associados aos desgastes físico e/ou emocional que podem ocorrer durante a entrevista. Para tanto, os pesquisadores comprometem-se a interromper a entrevista, acolher o participante e providenciar, se necessánio, seu encaminhamento ao serviço de Psicologia da Unidade de Referência.

Como benefícios, a pesquisa poderá contribuir para o fortalecimento das políticas públicas que enfatizam o envelhecimento ativo e a garantia dos direitos trabalhistas e previdenciários já previstos nas leis brasileiras de proteção ao idoso.

\section{Comentários e Consideraçöes sobre a Pesquisa:}

A pesquisa tem potencial para trazer contribuições na área do envelhecimento.

Considerações sobre os Termos de apresentaçäo obrigatória:

O pesquisador apresenta todos os termos obrigatórios: folha de rosto, projeto detalhado, TCLE e cronograma (considerado exequivel).

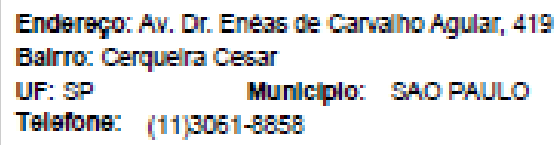




\section{EE USP USP - ESCOLA DE

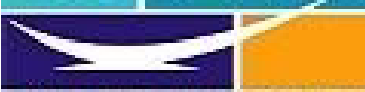

Continusç5 bo do Parecer: 2384277

Recomendaçöes:

O pesquisador deve:

-Inserir no TCLE que a entrevista será gravada.

-Inserir no projeto os riscos e benefícios da pesquisa, conforme constam no TCLE.

Conclusões ou Pendências e Lista de Inadequações:

Não há óbices éticos

Considerações Finais a critério do CEP:

- Este CEP informa a necessidade de registro dos resultados parciais e finais na Plataforma Brasil;

- Esta aprovação não substitui a autorização da instituiçäo coparticipante, antes do início da coleta de dados.

Este parecer foi elaborado baseado nos documentos abaixo relacionados:

\begin{tabular}{|c|c|c|c|c|}
\hline Tipo Documento & Arquivo & Postagem & Autor & Situaçäo \\
\hline $\begin{array}{l}\text { Informaçōes Básicas } \\
\text { do Projeto }\end{array}$ & $\begin{array}{l}\text { PB_INFORMAÇOES_BASICAS_DO_P } \\
\text { RO_ETO_1017430.pdf }\end{array}$ & $\begin{array}{c}25 / 10 / 2017 \\
14: 16: 09\end{array}$ & & Aceito \\
\hline $\begin{array}{l}\text { TCLE / Termos de } \\
\text { Assentimento / } \\
\text { Justificativa de } \\
\text { Auséncia }\end{array}$ & TCLE.docx & $\begin{array}{c}25 / 10 / 2017 \\
14: 15: 51\end{array}$ & $\begin{array}{l}\text { João Henrique de } \\
\text { Morais Ribeiro }\end{array}$ & Aceito \\
\hline $\begin{array}{l}\text { Projeto Detalhado / } \\
\text { Brochura } \\
\text { Investigador }\end{array}$ & Projeto.docx & $\begin{array}{c}23 / 10 / 2017 \\
13: 41: 14\end{array}$ & $\begin{array}{l}\text { João Henrique de } \\
\text { Morais Ribeiro }\end{array}$ & Aceito \\
\hline Folha de Rosto & Folha_rosto.pdf & $\begin{array}{c}23 / 10 / 2017 \\
13: 40: 40\end{array}$ & $\begin{array}{l}\text { Joâo Henrique de } \\
\text { Morais Ribeiro }\end{array}$ & Aceito \\
\hline Cronograma & CRONOGRAMA_docx & $\begin{array}{c}20 / 10 / 2017 \\
14: 53: 45\end{array}$ & $\begin{array}{l}\text { Joâo Henrique de } \\
\text { Morais Ribeiro }\end{array}$ & Aceito \\
\hline
\end{tabular}

Situaçäo do Parecer:

Aprovado

Necessita Apreciação da CONEP:

Nả๊

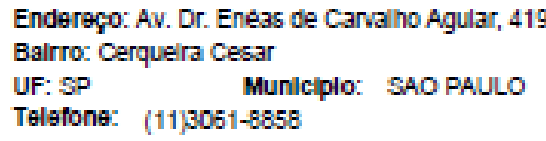

CEP: $\quad 05.403-000$ 


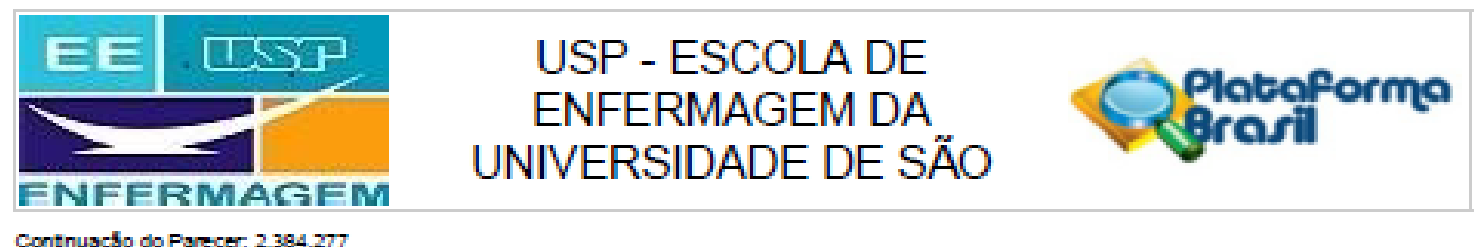

SAO PAULO, 16 de Novembro de 2017

Assinado por:

Lisabelle Mariano Rossato

(Coordenador)

Endereço: Av. Dr. Eneas de Carvaino Agular, 419

Balrro: Cerquelra Cesar

CEP: $05.403-000$

UF: SP MUniciplo: SAO PAULO

Telefone: (11)3051-8858

E-mall: cepeegusp.br 